Chemical Technology Division

\title{
LABORATORY DEVELOPMENT OF METHODS FOR CENTRALIZED TREATMENT OF LIQUID LOW-LEVEL WASTE AT OAK RIDGE NATIONAL LABORATORY
}
W. D. Arnold
D. T. Bostick
M. W. Burgess
P. A. Taylor
J. J. Perona
T. E. Kent

Date Published: October 1994

\author{
Prepared by \\ OAK RIDGE NATIONAL LABORATORY \\ Oak Ridge, Tennessee 37831-6285 \\ managed by \\ MARTIN MARIETTA ENERGY SYSTEMS, INC. \\ for the \\ U.S. DEPARTMENT OF ENERGY \\ under contract DE-AC05-84OR21400





\section{DISCLAIMER}

This report was prepared as an account of work sponsored by an agency of the United States Government. Neither the United States Government nor any agency thereof, nor any of their employees, make any warranty, express or implied, or assumes any legal liability or responsibility for the accuracy, completeness, or usefulness of any information, apparatus, product, or process disclosed, or represents that its use would not infringe privately owned rights. Reference herein to any specific commercial product, process, or service by trade name, trademark, manufacturer, or otherwise does not necessarily constitute or imply its endorsement, recommendation, or favoring by the United States Government or any agency thereof. The views and opinions of authors expressed herein do not necessarily state or reflect those of the United States Government or any agency thereof. 


\section{DISCLAIMER}

Portions of this document may be illegible in electronic image products. Images are produced from the best available original document. 
LIST OF TABLES $\ldots \ldots \ldots \ldots \ldots \ldots \ldots \ldots \ldots \ldots \ldots \ldots \ldots \ldots \ldots \ldots, v$

LIST OF FIGURES $\ldots \ldots \ldots \ldots \ldots \ldots \ldots \ldots \ldots \ldots \ldots \ldots \ldots \ldots \ldots \ldots \ldots$

ABSTRACT $\ldots \ldots \ldots \ldots \ldots \ldots \ldots \ldots \ldots \ldots \ldots \ldots \ldots \ldots \ldots \ldots \ldots \ldots \ldots$

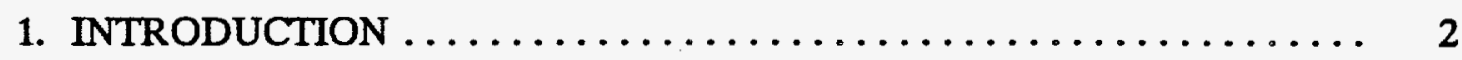

2. WASTE COMPOSITION $\ldots \ldots \ldots \ldots \ldots \ldots \ldots \ldots \ldots \ldots \ldots \ldots \ldots \ldots$

3. TREATMENT REQUIREMENTS $\ldots \ldots \ldots \ldots \ldots \ldots \ldots \ldots \ldots \ldots \ldots \ldots \ldots \ldots$

4. TEST MATERIALS $\ldots \ldots \ldots \ldots \ldots \ldots \ldots \ldots \ldots \ldots \ldots \ldots \ldots \ldots \ldots \ldots$

5. TEST PROCEDURES $\ldots \ldots \ldots \ldots \ldots \ldots \ldots \ldots \ldots \ldots \ldots \ldots \ldots \ldots \ldots \ldots \ldots \ldots$

6. STRONTIUM REMOVAL TEST RESULTS $\ldots \ldots \ldots \ldots \ldots \ldots \ldots \ldots, 17$

6.1 Strontium Removal by Coprecipitation with Stable Strontium Salts $\ldots . .17$

6.2 Strontium Removal by Coprecipitation with Stable Calcium Salts ...... 26

6.3 Strontium Removal with Sodium Titanate $\ldots \ldots \ldots \ldots \ldots \ldots \ldots . . \ldots \ldots$

6.4 Strontium Removal with Other Exchangers $\ldots \ldots \ldots \ldots \ldots \ldots \ldots$. 44

7. CESIUM REMOVAL TEST RESULTS $\ldots \ldots \ldots \ldots \ldots \ldots \ldots \ldots, 46$

7.1 Cesium Removal with KCCF Slurry ................. 46

7.2 Cesium Removal from Simulated NGLLLW with Granular KCCF ..... 56

7.3 Cesium Removal from Simulated MVST Supernate ............ 61

7.4 Cesium Sorption with Other Exchangers $\ldots \ldots \ldots \ldots \ldots \ldots \ldots \ldots .64$

8. RUTHENIUM REMOVAL TEST RESULTS ............... 66

9. NITRATE DESTRUCTION $\ldots \ldots \ldots \ldots \ldots \ldots \ldots \ldots \ldots \ldots \ldots \ldots \ldots$

10. FLOWSHEET DEVELOPMENT $\ldots \ldots \ldots \ldots \ldots \ldots \ldots \ldots \ldots \ldots \ldots \ldots \ldots$

11. FLOWSHEET DEMONSTRATION $\ldots \ldots \ldots \ldots \ldots \ldots \ldots \ldots \ldots \ldots \ldots \ldots$

12. PRELIMINARY SYSTEM DESIGN $\ldots \ldots \ldots \ldots \ldots \ldots \ldots \ldots \ldots \ldots, 84$

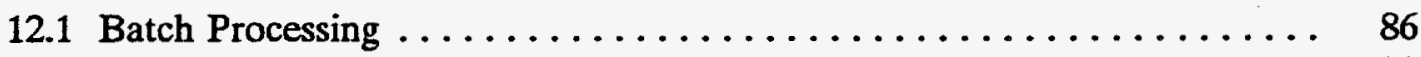

12.2 Continuous Processing $\ldots \ldots \ldots \ldots \ldots \ldots \ldots \ldots \ldots \ldots \ldots \ldots, 89$ 
CONTENTS, continued

13. SUMMARY AND CONCLUSIONS $\ldots \ldots \ldots \ldots \ldots \ldots \ldots \ldots \ldots \ldots$

14. REFERENCES $\ldots \ldots \ldots \ldots \ldots \ldots \ldots \ldots \ldots \ldots \ldots \ldots \ldots \ldots \ldots \ldots$

APPENDIX A ............................. 95

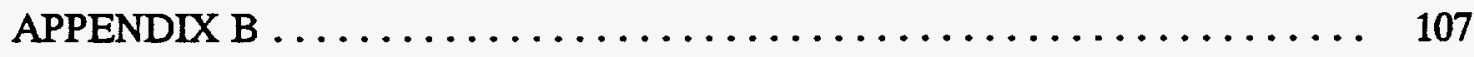




\section{LIST OF TABLES}

2.1 Composition of simulated newly generated liquid low-level waste.

3.1 Draft concentration limits for Class LII central solid waste disposal facility.

3.2 Required decontamination factors for principal contaminants in liquid low-level waste for discharge to the process waste system at Oak Ridge National Laboratory.

4.1 Composition of simulated waste solutions $\ldots \ldots \ldots \ldots \ldots \ldots \ldots \ldots$

4.2 Estimated acid needed for $\mathrm{pH}$ adjustment of simulated waste solutions .... 14

6.1 Strontium removal from simulated newly generated liquid low-level waste

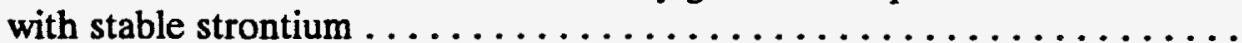

6.2 Strontium removal from simulated newly generated liquid low-level waste

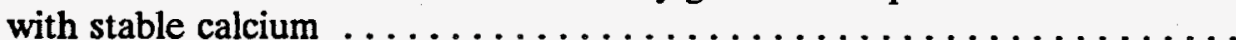

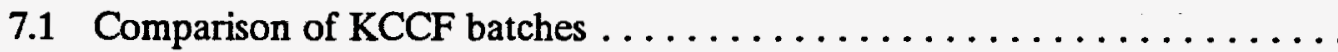

11.1 Strontium and cesium removal from simulated newly generated liquid low-level waste with a $\mathrm{SrCl}_{2}$ strike and two $\mathrm{KCCF}$ strikes

11.2 Removal of $\mathrm{Sr}, \mathrm{Cs}$, and $\mathrm{Ru}$ from simulated newly generated liquid low-level with a $\mathrm{SrCl}_{2}+$ ferric sulfate strike and two KCCF strikes . . . . . . . . .

11.3 Effect of processing delays and coagulant polymers on strontium and cesium removal from simulated newly generated liquid low-level waste ....

11.4 Strontium and cesium removal from diluted simulated newly generated liquid low-level waste with a $\mathrm{SrCl}_{2}+$ ferric sulfate strike and a $\mathrm{KCCF}$ strike .... 


\section{LIST OF FIGURES}

1.1 Flowsheet of the Oak Ridge National Laboratory liquid waste treatment systems with the proposed treatment facilities ...............

4.1 Titration of simulated waste solutions with $\mathrm{HCl} . \ldots \ldots \ldots \ldots \ldots \ldots$

6.1 Effect of added stable strontium on coprecipitation of ${ }^{85} \mathrm{Sr}$ from simulated newly generated liquid low-level waste. $\ldots \ldots \ldots \ldots \ldots \ldots \ldots \ldots \ldots$

6.2 Effect of $\mathrm{pH}$ of liquid-solid separation on ${ }^{85} \mathrm{Sr}$ coprecipitation from simulated newly generated liquid low-level waste with stable strontium. . . . . . . . .

6.3 Effect of mixing time on coprecipitation of ${ }^{85} \mathrm{Sr}$ from simulated newly generated liquid low-level with stable strontium

6.4 Effect of stable strontium solution volume on coprecipitation of ${ }^{85} \mathrm{Sr}$ from simulated newly generated liquid low-level waste with stable strontium .....

6.5 Effect of $\mathrm{pH}$ on strontium solubility in simulated newly generated liquid low-level waste. . . . . . . . . . . . . . . . . . . . .

6.6 Effect of aluminum concentration in simulated newly generated liquid low-level waste on strontium precipitation during $\mathrm{pH}$ adjustment. . . . . . . . .

6.7 Isotherm for strontium sorption from simulated newly generated liquid

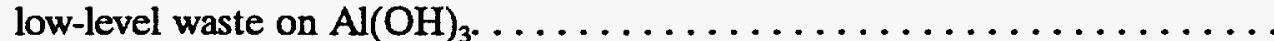

6.8 Effect of aluminum concentration on ${ }^{85} \mathrm{Sr}$ removal from simulated newly generated low-level waste with stable strontium.

6.9 Strontium removal from mixtures of simulated newly generated liquid low-level waste and simulated Melton Valley Storage Tank supernate with $\mathrm{SrCl}_{2}+$ ferric sulfate. . . . . . . . . . . . . . . . . . . . .

6.10 Effect of $\mathrm{pH}$ on strontium coprecipitation from simulated newly generated liquid low-level waste with stable calcium. . . . . . . . . . . . . .

6.11 Effect of calcium addition on strontium coprecipitation from simulated newly generated liquid low-level waste with stable calcium. . . . . . . . .

6.12 Effect of ferric sulfate on strontium coprecipitation with stable calcium. . . .

6.13 Effect of mixing time on strontium coprecipitation with stable calcium. . . . .

6.14 Effect of $\mathrm{pH}$ on strontium sorption from simulated newly generated liquid low-level waste on sodium titanate. 


\section{LIST OF FIGURES, Continued}

Page

6.15 Effect of mixing time at $\mathrm{pH} 8$ on strontium retention on sodium titanate ...

6.16 Effect of mixing time on strontium sorption from simulated newly generated liquid low-level waste on sodium titanate $\ldots \ldots \ldots \ldots \ldots \ldots \ldots$

6.17 Comparison of sodium titanate samples for strontium sorption from simulated newly generated liquid low-level waste $\ldots \ldots \ldots \ldots \ldots \ldots$

6.18 Effect of calcium on strontium sorption from simulated newly generated liquid low-level waste with sodium titanate.

6.19 Strontium sorption from mixtures of simulated newly generated liquid low-level waste and simulated Melton Valley Storage Tank supernate with sodium titanate.

7.1 Effect of $\mathrm{pH}$ on cesium sorption from simulated newly generated liquid low-level waste with in situ KCCF slurry. . . . . . . . . . . . . .

7.2 Isotherm for cesium sorption from simulated newly generated liquid low-level waste with KCCF slurry. . . . . . . . . . . . . . . .

7.3 Effects of potassium and sodium concentrations on cesium sorption from simulated newly generated liquid low-level waste with in situ KCCF slurry. . .

7.4 Effect of contact time on cesium sorption from simulated newly generated liquid low-level waste on in situ KCCF slurry. . . . . . . . . . . . .

7.5 Effect of preformed KCCF slurry age on cesium sorption from simulated newly generated liquid low-level waste.

7.6 Effect of mixing time on cesium sorption from simulated newly generated liquid low-level waste with in situ KCCF slurry.

7.7 Cesium sorption from simulated newly generated liquid low-level waste in a second strike with in situ KCCF slurry.

7.8 Effect of time after $\mathrm{pH}$ adjustment on cesium sorption from simulated newly generated liquid low-level waste with in situ KCCF slurry. . . . . . . . . . .

7.9 Isotherms for cesium sorption from simulated newly generated liquid low-level waste with granular KCCF. . . . . . . . . . . . . . . .

7.10 Cesium sorption from simulated Melton Valley Storage Tank supernates with in situ KCCF slurry. . . . . . . . . . . . . . . . . . . . 
7.11 Effect of mixing time on cesium sorption from simulated Melton Valley Storage Tank supernate with in situ KCCF slurry . . . . . . . . . . .

7.12 Cesium and strontium sorption from simulated newly generated liquid low-level waste and simulated Melton Valley Storage Tank supernate with Savannah River Site resin.

8.1 Ruthenium removal from simulated newly generated liquid low-level waste

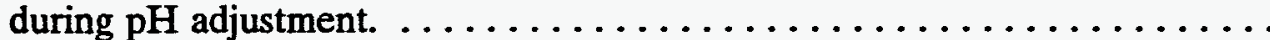

8.2 Effect of $\mathrm{pH}$ on ruthenium removal from simulated newly generated liquid low-level waste. . . . . . . . . . . . . . . . . . . . . .

8.3 Ruthenium removal from simulated newly generated liquid low-level waste with ferric sulfate.

8.4 Isotherm for ruthenium removal from simulated newly generated liquid low-level waste with ferric sulfate

10.1 Flowsheet for treatment of simulated newly generated liquid low-level waste.

11.1 Flow diagram for Wastewater Treatment Test Facility test system used for flowsheet demonstration . . . . . . . . . . . . . . . . . . . .

12.1 Preliminary design flowsheet for centralized treatment of liquid low-level waste-batch mode . . . . . . . . . . . . . . . . . . . . . .

12.2 Preliminary design flowsheet for centralized treatment of liquid low-level waste-continuous mode 


\section{ACRONYMS AND ABBREVIATIONS}

$\begin{array}{ll}\text { DCG } & \text { derived concentration guideline } \\ \text { DOE } & \text { U.S. Department of Energy } \\ \text { EIX } & \text { electrochemical ion exchange } \\ \text { ITE } & \text { in-tank evaporation } \\ \text { KCCF } & \text { potassium cobalt hexacyanoferrate } \\ \text { LLLW } & \text { liquid low-level waste } \\ \text { MVST } & \text { Melton Valley Storage Tank } \\ \text { NAC } & \text { nitrate to ammonia and ceramic (process) } \\ \text { NCCF } & \text { sodium cobalt hexacyanoferrate } \\ \text { NGLLW } & \text { newly generated liquid low-level waste } \\ \text { ORNL } & \text { Oak Ridge National Laboratory } \\ \text { ORR } & \text { Oak Ridge Reservation } \\ \text { PWTP } & \text { Process Waste Treatment Plant } \\ \text { SF } & \text { settling/filtration (vessel) } \\ \text { SRS } & \text { Savannah River Site } \\ \text { TRU } & \text { transuranic } \\ \text { WIPP } & \text { Waste Isolation Pilot Plant } \\ \text { WHPP } & \text { Waste Handling and Processing Plant } \\ \text { WTTF } & \text { Wastewater Treatment Test Facility }\end{array}$




\title{
LABORATORY DEVELOPMENT OF METHODS FOR CENTRALIZED TREATMENT OF LIQUID LOW-LEVEL WASTE AT OAK RIDGE NATIONAL LABORATORY
}

\author{
W. D. Amold, D. T. Bostick, M. W. Burgess, \\ P. A Taylor, J. J. Perona, and T. E. Kent
}

\begin{abstract}
Improved centralized treatment methods are needed in the management of liquid low-level waste (LLLW) at Oak Ridge National Laboratory (ORNL). LLLW, which usually contains radioactive contaminants at concentrations up to millicurie-per-liter levels, has accumulated in underground storage tanks for over 10 years and has reached a volume of over 350,000 gal. These wastes have been collected since 1984 and are a complex mixture of wastes from past nuclear energy research activities. The waste is a highly alkaline 4-5 $\mathrm{M} \mathrm{NaNO}_{3}$ solution with smaller amounts of other salts. This type of waste will continue to be generated as a consequence of future ORNL research programs. Future LLLW (referred to as newly generated LLLW or NGLLLW) is expected to a highly alkaline solution of sodium carbonate and sodium hydroxide with a smaller concentration of sodium nitrate. New treatment facilities are needed to improve the manner in which these wastes are managed. These facilities must be capable of separating and reducing the volume of radioactive contaminants to small stable waste forms. Treated liquids must meet criteria for either discharge to the environment or solidification for onsite disposal.
\end{abstract}

Laboratory testing was performed using simulated waste solutions prepared using the available characterization information as a basis. Testing was conducted to evaluate various methods for selective removal of the major contaminants. The major contaminants requiring removal from Melton Valley Storage Tank liquids are ${ }^{90} \mathrm{Sr}$ and ${ }^{137} \mathrm{Cs}$. Principal contaminants in NGLLLW are ${ }^{90} \mathrm{Sr},{ }^{137} \mathrm{Cs}$, and ${ }^{106} \mathrm{Ru}$. Strontium removal testing began with literature studies and scoping tests with several ion-exchange materials and sorbents. The methods and materials tested included chabazite and clinoptilolite zeolites, a resorcinol-formaldehyde-based resin (Savannah River Laboratory resin, also referred to as SRS), hydrous titanium oxide, magnesium hydroxide, sodium titanate, coprecipitation with 
calcium and strontium salts, and sorption by aluminum hydroxide. Of these methods, the SRS resin, sodium titanate, and the coprecipitation methods were evaluated further after the initial scoping tests. The SRS resin and sodium titanate were somewhat effective, but problems were experienced with consistency of performance between batches and suppliers. Coprecipitation and aluminum sorption methods were the most effective and underwent the most extensive test program. A combination of coprecipitation with stable $\mathrm{SrCl}_{2}$ and sorption onto aluminum hydroxide was the most effective for strontium removal. Stable $\mathrm{SrCl}_{2}$ is added to the waste at $\mathrm{pH} 13$, causing the precipitation of both stable and radioactive strontium carbonate. A second $\mathrm{pH}$ adjustment to $\mathrm{pH} 8.0$ causes precipitation of aluminum hydroxide, which sorbs additional amounts of strontium from the waste.

In laboratory studies for cesium removal, chabazite zeolite, the SRS resin, potassium cobalt hexacyanoferrate ( $\mathrm{KCCF}$ ), hydrous titanium phosphate, hydrous zirconium phosphate, Duolite CS-100 (Rohm and Haas), and ammonium molybdophosphate were tested. The most effective by far was the KCCF. Removal of cesium is accomplished by applying the $\mathrm{KCCF}$ as a finely divided slurry to the waste and removing the insoluble KCCF-cesium reaction product by filtration. Laboratory tests for removal of ${ }^{106} \mathrm{Ru}$ included sorption and precipitation tests using KCCF, cobalt sulfide, manganese dioxide, ferric hydroxide, and calcite. None of these materials were particularly effective, though ferric hydroxide treatment showed promise for partial removal. These wastes also contain high concentrations of sodium nitrate, which must be removed or otherwise destroyed if the treated waste is to be discharged to the environment.

Literature study indicates that there are several methods under development which could potentially deal with the nitrates. These nitrate destruction methods and also improved methods for ruthenium removal must be dealt with in future studies.

\section{INTRODUCTION}

The liquid low-level waste (LLLW) collection and treatment system at Oak Ridge National Laboratory (ORNL) currently treats over 400,000 gal of waste per year by 
reducing the volume through evaporation to approximately 20,000 gal of waste concentrate. The LLLW concentrate is stored in eight 50,000-gal vaulted underground storage tanks known as the Melton Valley Storage Tanks (MVSTs). LLLW concentrate has been accumulating in the MVSTs since 1984, and storage space is now very limited. It was originally proposed that MVST concentrate (consisting of liquids and sludges) be further evaporated to a salt cake at the proposed Waste Handling and Packaging Plant (WHPP) to be constructed at ORNL. ${ }^{1}$ It was anticipated that this salt cake would be accepted for disposal at the U.S. Department of Energy (DOE) Waste Isolation Pilot Plant (WIPP) in Carlsbad, New Mexico. However, uncertainty associated with implementation of WIPP has led to funding delays for the WHPP. To deal with continuing difficulties associated with limited LLLW concentrate storage capacity at the MVSTs, other treatment and disposal alternatives are being investigated. The treatment methods must be capable of treating existing LLLW concentrate and also LLLW to be generated as a consequence of future ORNL activities (hereafter referred to as newly generated LLLW or NGLLLW). An assessment of future activities and associated impacts on LLLW composition was conducted to determine the likely characteristics of NGLLLW. Due to the overall limited space for storage and disposal of radioactive wastes on the Oak Ridge Reservation (ORR), new treatment methods must create the smallest possible volume of highly radioactive Greater-than-Class-LII solid waste. These solid wastes might be permanently disposed of at DOE facilities (if available) or placed in retrievable storage facilities at ORNL until permanent disposal facilities are available. Treated liquids might either be discharged to the environment or solidified and disposed of on-site as Class LII waste.

A block diagram showing the existing ORNL waste treatment facilities and the proposed LLLW treatment facility is shown in Fig. 1.1. As described above, the current centralized treatment of these wastes involves evaporation of the LLLW and storage of the evaporator concentrate in the MVSTs. The concentrated LLLW stored in the 

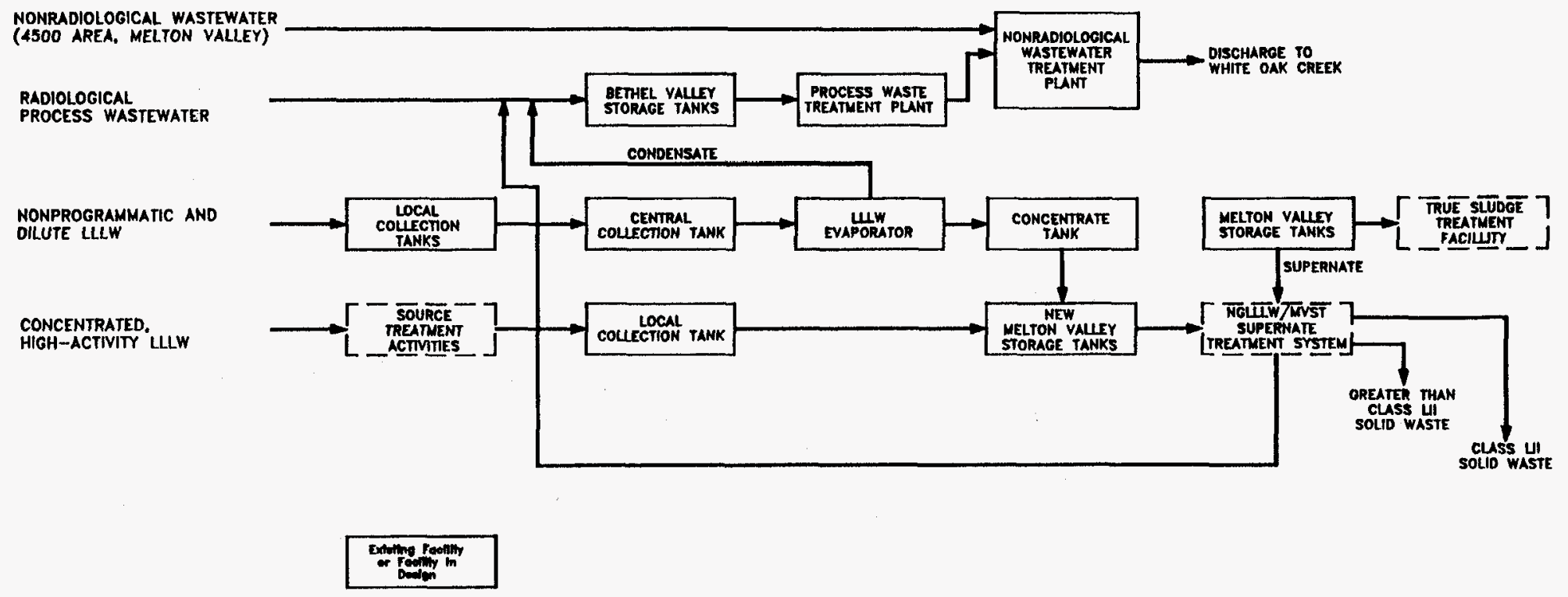

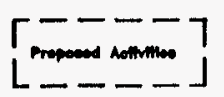

Fig. 1.1. Flowsheet of the Oak Ridge National Laboratory liquid waste treatment systems with the proposed treatment facilities. 
MVSTs consists of both solid sludges and liquid supernates. The proposed WHPP would mix the sludges, which contain significant quantities of transuranic (TRU) contaminants, with the supernates before evaporation to a salt cake. The salt cake would then be transported to the WIPP, which was designed for disposal of TRU wastes. No permanent disposal facilities for TRU wastes exist at ORNL. Retrievable storage facilities with limited storage capacity are available, but they are far too small for storage of MVST TRU sludges. Therefore, the WIPP must be made available before the WHPP can be implemented. To create additional storage space in the MVSTs without creating a TRU solid waste, only the MVST non-TRU supernate liquids can be treated. The MVST sludges are to be stored until WHPP or an equivalent TRU sludge treatment facility is available. To prevent further addition of TRU waste to the LLLW system, facilities which produce TRU waste are making plans to segregate TRU at the source.

One option for treatment of both NGLLLW and MVST supernates involves evaporation to a non-TRU salt cake using the WHPP systems; however, this treatment would result in a relatively large volume of Greater-than-Class-LII waste composed primarily of contaminated sodium nitrate. This waste could not be disposed of on-site, and the sodium nitrate waste form is undesirable due to its solubility in water and its potential for dispersion if exposed to environmental conditions. The present study focuses on the use of inorganic ion-exchange materials which can selectively sorb the radioactive contaminants and produce a small volume of inorganic solid waste. The inorganic sorbents do not decompose, and the contaminants are more likely to remain sorbed if exposed to environmental conditions. This characteristic makes them more amenable for long-term storage or disposal. Previous ORNL studies have shown that inorganic transition-metal hexacyanoferrate compounds can selectively sorb cesium and that sodium titanate can selectively sorb strontium from simulated MVST supernates. ${ }^{2}$ The present study initially focuses on the use of these two materials for treatment of simulated NGLLLW, which is likely to contain radioactive $\mathrm{Cs}, \mathrm{Sr}$, and $\mathrm{Ru}$. Additional tests are performed to evaluate alternatives for the hexacyanoferrate compounds and to evaluate an improved method for removing ${ }^{90} \mathrm{Sr}$ by coprecipitation with stable $\mathrm{SrCl}_{2}$. The removal of ${ }^{103,106} \mathrm{Ru}$ from NGLLLW is also investigated using various treatment methods, and options 
of nitrate destruction are evaluated. The results of the bench-scale studies have led to the development of a preliminary flowsheet for NGLLLW and MVST supernate treatment.

\section{WASTE COMPOSITION}

Two waste streams were considered in this study: (1) MVST supernate and (2) NGLLLW. Though most of the principal contaminants are common for the two wastes, the basic compositions are somewhat different. The composition of MVST supernates was determined from sampling and analysis, the results of which are published in an ORNL document. ${ }^{3}$ Similar analytical data, however, are not available for NGLLLW. To estimate NGLLLW composition, it was necessary to use generator survey information and also predict changes in the composition based on forecasting of future ORNL program activities. In 1989, the LLLW data base was developed to collect data on the composition of LLLW streams sent to the centralized LLLW system. ${ }^{4}$ Survey forms were sent to each generator to document the types and amounts of waste materials discharged to the LLLW system. Analytical data for waste samples were also reported if available. The information from this data base was used to estimate the composition of LLLW discharged to the centralized system. Since the treatment systems are not likely to be implemented until 1998 or beyond, an important factor to consider in estimating waste composition is the effect that program activities may have on future waste composition. The future treatment system is also likely to collect effluents from source treatment activities. As such, assumptions must be made as to the extent of LLLW decontamination provided by the pretreatment. All of these factors were collectively used to estimate waste composition for NGLLLW. Appendix A of this report details the waste compositions, outlines the assumptions made for future ORNL activities, and discusses the manner in which the composition of NGLLLW was estimated. Table 2.1 gives the composition for the simulated NGLLLW used in the test program. 
Table 2.1. Composition of simulated newly generated liquid low-level waste (NGLLLW)

\begin{tabular}{|c|c|c|}
\hline & $\begin{array}{c}\text { Total amount } \\
\text { per year }\end{array}$ & NGLLLW conc. \\
\hline \multicolumn{3}{|c|}{ Radionuclides } \\
\hline${ }^{137,134} \mathrm{Cs}$ & $11,800 \mathrm{Ci}$ & $100 \mathrm{mCi} / \mathrm{L}$ \\
\hline${ }^{103,106} \mathrm{Ru}$ & $15,600 \mathrm{Ci}$ & $130 \mathrm{mCi} / \mathrm{L}$ \\
\hline${ }^{90} \mathrm{Sr}$ & $2,300 \mathrm{Ci}$ & $20 \mathrm{mCi} / \mathrm{L}$ \\
\hline \multicolumn{3}{|c|}{ Nonradioactive components } \\
\hline $\mathrm{NaOH}$ & $3500 \mathrm{lb}$ & $0.34 M$ \\
\hline $\mathrm{NaNO}_{3}$ & $1360 \mathrm{lb}$ & $0.06 M$ \\
\hline $\mathrm{NaAlO}_{2}$ & $300 \mathrm{lb}$ & $0.012 M$ \\
\hline $\mathrm{Na}_{2} \mathrm{CO}_{3}$ & $16,200 \mathrm{lb}$ & $0.59 M$ \\
\hline $\mathrm{NaCl}$ & $500 \mathrm{lb}$ & $0.034 M$ \\
\hline $\mathrm{LiCl}$ & $275 \mathrm{lb}$ & $0.025 M$ \\
\hline
\end{tabular}

\section{TREATMENT REQUIREMENTS}

The extent of contaminant removal required can depend on many factors. For wastewaters, the required removal efficiency typically depends on regulatory discharge limits. In this case, however, the required removal rate or decontamination factor also depends on the potential characteristics of solid secondary wastes produced from ORNL process waste treatment activities. It is anticipated that the liquid effluent from the new LLLW treatment system will be discharged to the ORNL Process Waste Treatment Plant (PWTP), which treats about 70 million gallons per year of more dilute process wastewater. After subsequent treatment at the Nonradiological Wastewater Treatment Plant, the wastewater is discharged to White Oak Creek. In future upgrades, the PWTP will use a zeolite ion-exchange system to remove both ${ }^{137} \mathrm{Cs}$ and ${ }^{90} \mathrm{Sr}$ from process wastewater. The zeolite will not be regenerated and will be disposed of as a solid waste when it becomes exhausted. If the current wastewater composition does not change, the solid zeolite waste will be considered a Class LII solid waste and will be disposed of on the ORR. If, 
however, the levels of ${ }^{137} \mathrm{Cs}$ and ${ }^{90} \mathrm{Sr}$ in the process wastewater significantly increase, the spent zeolite may contain proportionately higher concentrations of ${ }^{137} \mathrm{Cs}$ and ${ }^{90} \mathrm{Sr}$. Due to the increased contaminant levels, the zeolite may not meet the Class LII limits (Table 3.1). This would prohibit the disposal of the zeolite on the ORR and would require significant space at temporary retrievable storage facilities. To prevent the spent zeolite from exceeding the Class LII limits, the concentrations of ${ }^{137} \mathrm{Cs}$ and ${ }^{90} \mathrm{Sr}$ must be limited. These concentrations were calculated and are given in Table 3.2.

The decontamination factor required for ${ }^{103,106} \mathrm{Ru}$ was estimated by using the DOE Order 5400.5 derived concentration guideline (DCG) for discharge of wastewater to the environment. This guideline is used because, unlike cesium and strontium, the ruthenium is not removed or otherwise concentrated in a solid waste form during treatment of process wastewater. The DCGs for ${ }^{103} \mathrm{Ru}$ and ${ }^{106} \mathrm{Ru}$ are $50 \mathrm{nCi} / \mathrm{L}$ and $6 \mathrm{nCi} / \mathrm{L}$ respectively. To be conservative, the lower ${ }^{106} \mathrm{Ru}$ limit was chosen for the calculation. The sum-of-the-fractions rule stated in DOE Order 5400.5 requires that the sum of the fractional DCGs calculated for all contaminants must be less than 1.0; therefore, it is assumed that ${ }^{106} \mathrm{Ru}$ could be discharged at maximum of $10 \%$ of the $\mathrm{DCG}$, or $0.6 \mathrm{nCi} / \mathrm{L}$. Applying an estimated dilution factor of 1300:1 gives a concentration of $766 \mathrm{nCi} / \mathrm{L}$ for the maximum NGLLLW effluent concentration. The NGLLLW estimated concentration for ${ }^{103,106} \mathrm{Ru}$ was divided by $766 \mathrm{nCi} / \mathrm{L}$ to give a required decontamination factor of 173,000 . A similar calculation was performed for MVST supernates assuming the same treatment rate as the NGLLLW (55,000 gal/year). Results of the calculations are given in Table 3.2.

\section{TEST MATERIALS}

Sorption measurements were made using three simulated waste solutions that had the compositions shown in Table 4.1. The solutions were prepared by dissolving reagent-grade chemicals in water. The simulated supernates and many of the simulated NGLLLW solutions were prepared from deionized water and were filtered through $0.45-\mu \mathrm{m}$ membranes before use. Simulated NGLLLW solutions prepared from process water (in 
Table 3.1. Draft concentration limits for Class LII central solid waste disposal facility

\begin{tabular}{cccc}
\hline Nuclide & $\begin{array}{c}\text { Concentration } \\
\left(\mathrm{Ci} / \mathrm{m}^{3}\right)\end{array}$ & Nuclide & $\begin{array}{c}\text { Concentration } \\
\left(\mathrm{Ci} / \mathrm{m}^{3}\right)\end{array}$ \\
\hline${ }^{3} \mathrm{H}$ & $1.2 \mathrm{E}+06$ & ${ }^{155} \mathrm{Eu}$ & $1.0 \mathrm{E}+06$ \\
${ }^{10} \mathrm{Be}$ & $2.0 \mathrm{E}+00$ & ${ }^{232} \mathrm{Th}$ & $4.5 \mathrm{E}-07$ \\
${ }^{14} \mathrm{C}$ & $2.0 \mathrm{E}-04$ & ${ }^{233} \mathrm{U}$ & $2.4 \mathrm{E}-05$ \\
${ }^{2} \mathrm{Na}$ & $1.0 \mathrm{E}+06$ & ${ }^{235} \mathrm{U}$ & $2.5 \mathrm{E}-05$ \\
${ }^{60} \mathrm{Co}$ & $1.0 \mathrm{E}+06$ & ${ }^{238} \mathrm{U}$ & $2.7 \mathrm{E}-05$ \\
${ }^{63} \mathrm{Ni}$ & $2.8 \mathrm{E}-02$ & ${ }^{237} \mathrm{~Np}$ & $1.0 \mathrm{E}-08$ \\
${ }^{90} \mathrm{Sr}$ & $8.9 \mathrm{E}-01$ & ${ }^{238} \mathrm{Pu}$ & $1.5 \mathrm{E}-05$ \\
${ }^{93} \mathrm{Zr}$ & $2.6 \mathrm{E}-04$ & ${ }^{239} \mathrm{Pu}$ & $2.9 \mathrm{E}-07$ \\
${ }^{99} \mathrm{Tc}$ & $5.5 \mathrm{E}-06$ & ${ }^{241} \mathrm{Pu}$ & $9.4 \mathrm{E}-03$ \\
${ }^{113 \mathrm{~m}} \mathrm{Cd}$ & $9.8 \mathrm{E}+03$ & ${ }^{242} \mathrm{Pu}$ & $5.0 \mathrm{E}-04$ \\
${ }^{121 \mathrm{~m}} \mathrm{Sn}$ & $5.7 \mathrm{E}-02$ & ${ }^{241} \mathrm{Am}$ & $1.3 \mathrm{E}-04$ \\
${ }^{137} \mathrm{Cs}$ & $2.5 \mathrm{E}-01$ & ${ }^{243} \mathrm{Am}$ & $1.8 \mathrm{E}-05$ \\
${ }^{151} \mathrm{Sm}$ & $2.6 \mathrm{E}+01$ & ${ }^{243} \mathrm{Cm}$ & $1.0 \mathrm{E}+00$ \\
${ }^{152} \mathrm{Eu}$ & $1.3 \mathrm{E}+03$ & ${ }^{244} \mathrm{Cm}$ & $2.1 \mathrm{E}-04$ \\
${ }^{154} \mathrm{Eu}$ & $5.1 \mathrm{E}+06$ & ${ }^{252} \mathrm{Cf}$ & $1.0 \mathrm{E}+06$ \\
\hline
\end{tabular}


Table 32. Required decontamination factors for principal contaminants in liquid low-level waste for discharge to the process waste system at Oak Ridge National Laboratory

\begin{tabular}{|c|c|c|c|c|}
\hline Radionuclide & $\begin{array}{l}\text { Maximum PWS } \\
\text { waste feed } \\
\text { concentration }\end{array}$ & $\begin{array}{l}\text { A: Estimated feed } \\
\text { or supernate } \\
\text { concentration }\end{array}$ & $\begin{array}{l}\text { B: Max, allowed } \\
\text { effluent conc.b }\end{array}$ & $\begin{array}{l}\text { Required } \\
\text { decontamination } \\
\text { factor: } A / B\end{array}$ \\
\hline \multicolumn{5}{|c|}{ Newty generated biquid lowtevel waste } \\
\hline${ }^{137} \mathrm{Cs}$ & $59.4 \mathrm{nCi} / \mathrm{L}$ & $100 \mathrm{mCi} / \mathrm{L}$ & $0.076 \mathrm{mCi} / \mathrm{L}$ & 1320 \\
\hline${ }^{90} \mathrm{Sr}$ & $196 \mathrm{nCiL}$ & $19.5 \mathrm{mCi} / \mathrm{L}$ & $0.25 \mathrm{mCi} / \mathrm{L}$ & 78 \\
\hline${ }^{108,106} \mathrm{Ru}$ & $0.6 \mathrm{nCi} / \mathrm{L}^{1}$ & $130 \mathrm{mCi} / \mathrm{L}$ & $760 \mathrm{nCi} / \mathrm{L}$ & 173,000 \\
\hline \multicolumn{5}{|c|}{ Melton Valley Storage Tank waste } \\
\hline${ }^{137} \mathrm{Cs}$ & $59.4 \mathrm{nCi} / \mathrm{L}$ & $5.95 \mathrm{mCi} / \mathrm{L}$ & $0.076 \mathrm{mCi} / \mathrm{L}$ & 78 \\
\hline${ }^{90} \mathrm{Sr}$ & $196 \mathrm{nCi} / \mathrm{L}$ & $0.19 \mathrm{mCi} / \mathrm{L}$ & $0.25 \mathrm{mCi} / \mathrm{L}$ & 0.76 \\
\hline${ }^{103,106} \mathrm{Ru}$ & $0.6 \mathrm{nCi} / \mathrm{L}^{1}$ & $<0.057 \mathrm{mCi} / \mathrm{L}$ & $760 \mathrm{nCi} / \mathrm{L}$ & $<74$ \\
\hline
\end{tabular}

'Process waste stream.

bilution factor of 1300:1 is assumed.

'Maximum process waste concentration based on DOE Order 5400.5, $10 \%$ of derived concentration guideline. 
Table 4.1. Composition of simulated waste solutions

\begin{tabular}{|c|c|c|c|}
\hline & \multicolumn{3}{|c|}{ Waste solution } \\
\hline & NGLLLW & Supernate & $\begin{array}{l}\text { Conc. } \\
\text { supernate }\end{array}$ \\
\hline \multicolumn{4}{|c|}{ Concentration by component (mol/L) } \\
\hline $\mathrm{NaOH}$ & 0.34 & 0.24 & 0.31 \\
\hline $\mathrm{Na}_{2} \mathrm{CO}_{3}$ & 0.59 & 0.14 & 0.18 \\
\hline $\mathrm{NaNO}_{3}$ & 0.06 & 3.90 & 5.0 \\
\hline $\mathrm{NaCl}$ & 0.034 & 0.10 & 0.13 \\
\hline $\mathrm{LiCl}$ & 0.025 & $N^{b}$ & NP \\
\hline $\mathrm{KNO}_{3}$ & NP & 0.24 & 0.31 \\
\hline $\mathrm{Al}\left(\mathrm{NO}_{3}\right)_{3}$ & NP & 0.005 & 0.0065 \\
\hline $\mathrm{NaAlO}_{2}$ & 0.012 & NP & NP \\
\hline $\mathrm{CaCO}_{3}$ & NP & 0.0001 & 0.00013 \\
\hline $\mathrm{Zn}\left(\mathrm{NO}_{3}\right)_{2}$ & NP & 0.001 & 0.0013 \\
\hline $\mathrm{CsCl}$ & $8.4 \times 10^{-6 c} \mathrm{c}$ & $5.0 \times 10^{-7 d}$ & $6.5 \times 10^{-7 e}$ \\
\hline $\mathrm{SrCl}_{2}$ & $1.6 \times 10^{-6 f}$ & $1.5 \times 10^{-8 g}$ & \\
\hline $\mathrm{RuCl}_{3}$ & $3.2 \times 10^{-7} \mathrm{~b}$ & & \\
\hline & pH & & \\
\hline \multirow[t]{2}{*}{ Total solution } & 13.1 & 12.7 & 13.1 \\
\hline & Density $(g / m L$ & & \\
\hline Total Solution & 1.074 & 1.242 & 1.308 \\
\hline
\end{tabular}

${ }^{2}$ Newly generated liquid low-level waste.

b $\mathrm{NP}=$ not present.

'Equivalent to $99.4 \mathrm{mCi} /{ }^{137} \mathrm{Cs}$.

${ }^{d}$ Equivalent to $5.9 \mathrm{mCi} /{ }^{137} \mathrm{Cs}$.

Equivalent to $7.7 \mathrm{mCi} / \mathrm{L}{ }^{137} \mathrm{Cs}$.

Equivalent to $19.4 \mathrm{mCi} / \mathrm{L}{ }^{\circ} \mathrm{Sr}$.

Equivalent to $0.19 \mathrm{mCi} /{ }^{90} \mathrm{Sr}$.

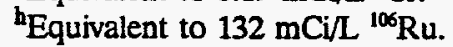


preparation for pilot-plant studies) were not filtered. The simulated NGLLLW, which contains $0.59 \mathrm{~mol} / \mathrm{L} \mathrm{Na} \mathrm{CO}_{3}$ and $0.33 \mathrm{~mol} / \mathrm{L} \mathrm{NaOH}$ at $\mathrm{pH} 13.1$, represents the anticipated composition of LLLW generated in the future at ORNL as described in Sect. 2. The composition of the simulated supernate closely approximates that of the actual supernate in MVST W-29 (ref. 3). This solution contains about $4.5 \mathrm{~mol} / \mathrm{L} \mathrm{NaNO}_{3}$ and $0.25 \mathrm{~mol} / \mathrm{L}$ $\mathrm{KNO}_{3}$ at $\mathrm{pH}$ 12.7. The supernate concentrate represents the composition of the supernate concentrated $30 \%$ by the evaporation of water. This simulates removal of excess water from the MVST supernates by either sparging with air or in-tank evaporation (ITE) or by pumping the supernates to an auxiliary on-site evaporator for out-of-tank evaporation. The $\mathrm{pH}$ of this solution was 13.1. The behavior of the radionuclides in the development studies was measured by adding the expected molar concentrations of the chlorides of $\mathrm{Cs}, \mathrm{Sr}$, or $\mathrm{Ru}$ to the solution and tracing the solution with ${ }^{137} \mathrm{Cs},{ }^{85} \mathrm{Sr}$, or ${ }^{106} \mathrm{Ru}$ for counting purposes. The measured densities of the solutions were $1.074 \mathrm{~g} / \mathrm{mL}$ for the simulated NGLLLW, $1.242 \mathrm{~g} / \mathrm{mL}$ for the simulated supernate, and $1.308 \mathrm{~g} / \mathrm{mL}$ for the supernate concentrate.

Samples of the solutions were titrated to determine the amount of acid needed for $\mathrm{pH}$ adjustment (Fig. 4.1 and Table 4.2). Considerably more acid was required to neutralize the newly generated waste because of its higher concentrations of $\mathrm{NaOH}, \mathrm{Na}_{2} \mathrm{CO}_{3}$, and aluminum. Aluminum hydroxide precipitated from the solutions in the $\mathrm{pH}$ range 11 to 9 , and the precipitate redissolved in the $\mathrm{pH}$ range 5 to 4 .

The $\mathrm{pH}$ of the supernate is expected to change as a result of the ITE process, which began in 1992. ITE involves sparging of the MVSTs with dry air to evaporate water and create additional capacity for future waste storage. The carbon dioxide sparged into the tanks along with the air is expected to be absorbed by the supernate and lower the $\mathrm{pH}$. Calculations were performed (see Appendix B) which predict that one-half of the carbon dioxide entering with the air will be absorbed and that over a 2-year period the $\mathrm{pH}$ of the supernates will drop below 9 .

Most of the cesium sorption studies were performed using potassium cobalt hexacyanoferrate (KCCF), which is prepared by reacting potassium ferrocyanide, 


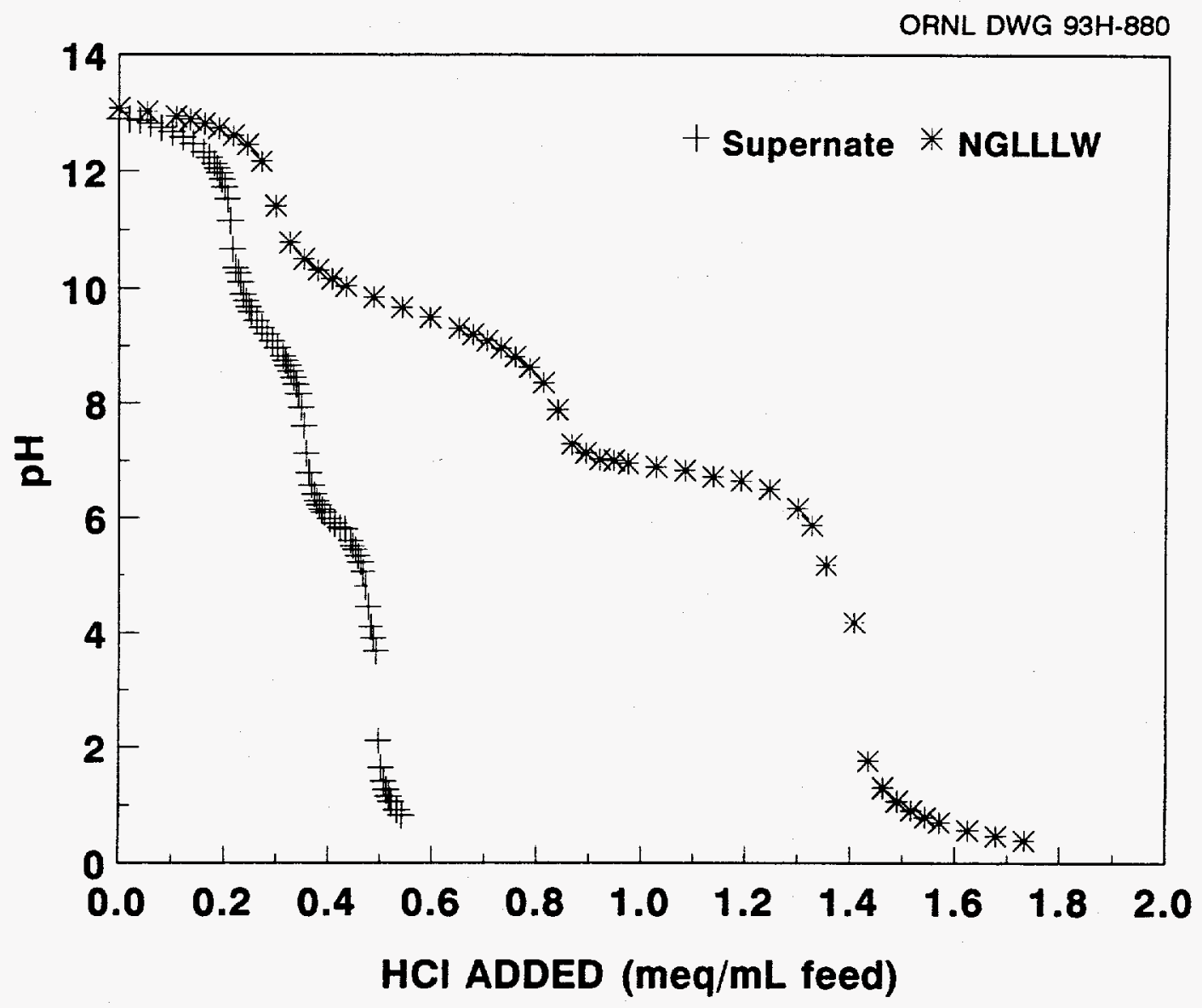

Fig. 4.1. Titration of simulated waste solutions with $\mathbf{H C l}$. Procedure: Ten-milliliter samples of simulated waste solutions were titrated with $5.4 \mathrm{eq} / \mathrm{L} \mathrm{HCl}$. NGLLLW = newly generated liquid low-level waste. 
Table 4.2 Estimated acid needed for $\mathrm{pH}$ adjustment of simulated waste solutions

\begin{tabular}{ccc} 
& \multicolumn{2}{c}{ Gallons of $36 \mathrm{~N} \mathrm{H}_{2} \mathrm{SO}_{4} / 1000 \mathrm{gal}$} \\
waste \\
\cline { 2 - 3 } $\mathrm{pH}$ & NGLLLW $^{\mathrm{a}}$ & Supernate \\
\hline 13.1 & 0 & -- \\
12.7 & -- & 0 \\
12.0 & 7.7 & 5.2 \\
11.0 & 8.6 & 5.9 \\
10.0 & 12.0 & 6.5 \\
9.0 & 19.7 & 8.1 \\
8.0 & 23.0 & 9.6 \\
\hline
\end{tabular}

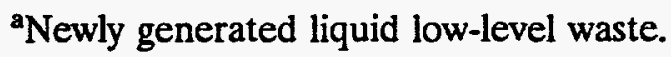

$\mathrm{K}_{4} \mathrm{Fe}(\mathrm{CN})_{6}$, with cobalt nitrate, $\mathrm{Co}\left(\mathrm{NO}_{3}\right)_{2}$, to precipitate $\mathrm{K}_{2} \mathrm{CoFe}(\mathrm{CN})_{6}$. Dry granular material, wet preformed slurries, and in situ preparation methods were used. The in situ slurries were formed by dissolving $\mathrm{K}_{4} \mathrm{Fe}(\mathrm{CN})_{6}$ in the waste samples and then adding $\mathrm{Co}\left(\mathrm{NO}_{3}\right)_{2}$ to precipitate $\mathrm{KCCF}$ within the waste samples. The preformed slurry was prepared by adding $\mathrm{Co}\left(\mathrm{NO}_{3}\right)_{2}$ solution to $\mathrm{K}_{4} \mathrm{Fe}(\mathrm{CN})_{6}$ solution, and the resultant $\mathrm{KCCF}$ slurry was added to the waste samples. Stoichiometric amounts of the reactants were used in both preparations. Several batches of granular KCCF were prepared by the method of Prout, Russell, and Groh, ${ }^{5}$ which involves preparation of a slurry; washing, dewatering, and drying the slurry; and then breaking up the dried cake into 20 to 50 mesh size particles. A reference batch prepared by the same method for earlier studies at ORNL ${ }^{2}$ was also used in some of the tests.

Other potential sorbents used for cesium sorption were sodium cobalt hexacyanoferrate (NCCF), prepared at ORNL by the same method used for KCCF; gelderived microspheres of titanium phosphate or zirconium phosphate, prepared at ORNL by an internal gelation technique ${ }^{6}$; Ionsiv IE-96, a synthetic chabazite zeolite obtained 
from Union Carbide Corporation; Duolite CS-100, a phenolic cation exchange resin obtained from Rohm \& Haas; and Savannah River Site resin, a resorcinol-based resin developed at $\mathrm{SRS}^{7}$ and prepared by Boulder Scientific Company.

Sodium titanate used for strontium sorption was obtained from several sources as described in Sect. 5. The calcium chloride and strontium chloride used in coprecipitation tests with strontium were high-purity laboratory chemicals. A ferric sulfate solution (also known under trade name as Ferri-floc) used for settling purposes and for strontium and ruthenium removal was obtained from Tennessee Chemical Company. Materials tested for ruthenium removal included manganese dioxide obtained from CSA, a division of Lake Industries, and cobalt sulfide obtained from Johnson Matthey.

\section{TEST PROCEDURES}

Most of the sorption measurements were made in batch equilibration tests. The solutions and exchangers were contacted in screw-cap polycarbonate centrifuge tubes by mixing on a Labquake shaker, which rocks the samples from $-45^{\circ}$ to $+45^{\circ}$ from horizontal at 20 cycles per minute. In most cases, three samples were included in each data set. The solutions contained stable $\mathrm{CsCl}, \mathrm{SrCl}_{2}$, or $\mathrm{RuCl}_{3}$ equivalent to the molar concentration of the radionuclides expected in the actual wastes and were traced with ${ }^{137} \mathrm{Cs},{ }^{85} \mathrm{Sr}$, or ${ }^{106} \mathrm{Ru}$. Solution volumes were determined from the weights and densities of the solutions. Solid exchangers were weighed directly and added to the tubes. In situ KCCF slurry was introduced to the tubes by adding measured volumes of $\mathrm{K}_{4} \mathrm{Fe}(\mathrm{CN})_{6}$ solution to the tubes and then adding measured volumes of $\mathrm{Co}\left(\mathrm{NO}_{3}\right)_{2}$ solution. The preformed KCCF slurry was prepared by adding a stoichiometric amount of $0.3 \mathrm{~mol} / \mathrm{L}$ $\mathrm{Co}\left(\mathrm{NO}_{3}\right)_{2}$ to $0.5 \mathrm{~mol} / \mathrm{L} \mathrm{K}_{4} \mathrm{Fe}(\mathrm{CN})_{6}$. Measured volumes of the preformed slurry were pipetted to the centrifuge tubes. The tubes were weighed at the beginning and the end of the equilibration periods to determine any solution loss. At the end of the equilibration period, the tubes were centrifuged for $30 \mathrm{~min}$ at $5000 \mathrm{rcf}$ and the count rates and $\mathrm{pH}$ values of the centrifuged solutions were measured. Many of the strontium coprecipitation 
tests were conducted in $20-\mathrm{mL}$ polyethylene vials. The solutions were mixed on a Labquake shaker or with magnetic stirrers.

Test data were used in the following calculations:

Decontamination factor $(\mathrm{DF})=C_{\mathrm{i}} / C_{\mathrm{f}}$,

Sorption ratio $\left(R_{\mathrm{s}}, L / \mathrm{kg}\right)=\left(C_{\mathrm{i}}-C_{\mathrm{f}}\right) V / C_{\mathrm{f}} W$,

Concentrations in solution $\left(M_{\mathrm{f}}, \mathrm{meq} / \mathrm{L}\right)=M_{\mathrm{i}} \times C_{\mathrm{f}} / C_{\mathrm{i}}$,

Concentrations on the exchangers $\left(M_{\mathrm{e}} \mathrm{meq} / \mathrm{kg}\right)=M_{\mathrm{f}} \times R_{\mathrm{s}}$,

where

$C_{\mathrm{i}}=$ count rate of the initial solution,

$C_{\mathrm{f}}=$ count rate of the final solution,

$V=$ initial volume of the solution $(\mathrm{mL})$,

$W=$ exchanger weight $(\mathrm{g})$.

Slightly larger scale tests were needed for determining sorption rates for cesium and strontium using selected sorbent materials. These tests were performed using a small batch mixer, consisting of a 5 -cm-diam vessel with four 1.0 - by $0.5-\mathrm{cm}$ baffles placed at $90^{\circ}$. Stirring speed was $300 \mathrm{rpm}$ using a $2.5-$ by $1.2-\mathrm{cm}$ mixer impeller. Cesium sorption rates were measured by adding $\mathrm{K}_{4} \mathrm{Fe}(\mathrm{CN})_{6}$ solution to the simulated waste solution in the vessel as it was being stirred and then adding $\mathrm{Co}\left(\mathrm{NO}_{3}\right)_{2}$ solution. Samples of the reaction mixture were withdrawn at timed intervals and centrifuged for $1 \mathrm{~min}$ at $700 \mathrm{rcf}$. The solutions were decanted and centrifuged for $30 \mathrm{~min}$ at $5000 \mathrm{rcf}$. The count rates of three aliquots from each twice-centrifuged sample were measured. Strontium sorption rates were measured by adding sodium titanate to the simulated NGLLLW as it was being stirred. Samples were withdrawn and analyzed as described for cesium. 


\section{STRONTIUM REMOVAL TEST RESULTS}

Bench-scale experiments were performed in which several different treatment methods and test parameters were evaluated for removal of ${ }^{90} \mathrm{Sr}$ from simulated NGLLLW and MVST supernate. The treatment methods tested involved materials used for ion exchange, sorption, and coprecipitation of ${ }^{90} \mathrm{Sr}$. If a certain treatment material was effective in initial scoping tests, additional tests were conducted to determine optimum treatment parameters such as $\mathrm{pH}$ and contact time. Equilibrium studies were performed for the most promising treatment materials to determine the maximum loading capacity. To prepare for pilot-scale testing of the treatment process, other bench tests were performed to evaluate the effect of operating parameters such as mixing intensity, order of addition of treatment chemicals, and solid-liquid separation methods.

\subsection{Strontium Removal by Coprecipitation with Stable Strontium Salts}

Coprecipitation of alkaline earths by the addition of lime and soda ash is a standard method for removing hardness from water. This treatment method has also been used to remove strontium from radioactive waste solutions. ${ }^{8.9}$ The most effective procedure tested in our studies for strontium removal from simulated NGLLLW was coprecipitation with stable strontium, followed by a liquid-solid separation at $\mathrm{pH} 13$ and adjustment of the $\mathrm{pH}$ to 8 . Cumulative strontium decontamination factors several times the needed decontamination factor of 80 were obtained with this treatment using as little as $50 \mathrm{ppm}$ strontium. The decontamination factor in the $\mathrm{SrCl}_{2}$ strike was about 30 with 50 ppm strontium, and the remainder of the strontium removal was by sorption on the $\mathrm{Al}(\mathrm{OH})_{3}$ that forms during $\mathrm{pH}$ adjustment. Strontium decontamination and flocculation of the solids were improved by 2-3 times by the addition of $25 \mathrm{ppm}$ iron, added as ferric sulfate, in the $\mathrm{SrCl}_{2}$ strike.

Strontium removal from simulated NGLLLW increased as the amount of stable strontium added in the strike was increased to about $100 \mathrm{ppm}$. Above $100 \mathrm{ppm}$, removal of strontium did not improve significantly (Fig. 6.1) The decontamination factor at $\mathrm{pH} 13$ was about 2.8 with $10 \mathrm{ppm}$ strontium, increasing to 30 with 100 or $200 \mathrm{ppm}$ strontium 


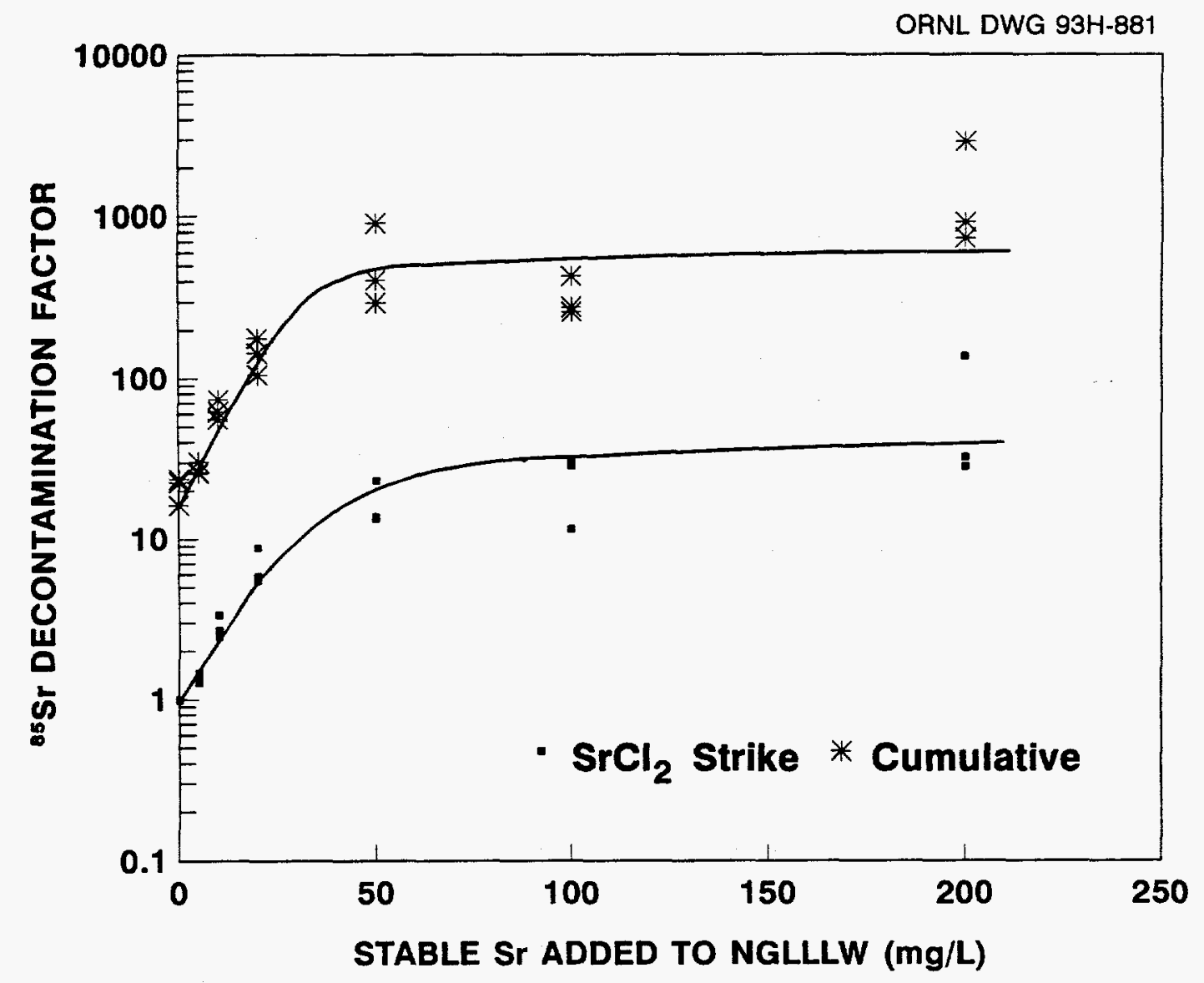

Fig. 6.1. Effect of added stable strontium on coprecipitation of ${ }^{85} \mathrm{Sr}$ from simulated newly generated liquid low-level waste (NGLLLW). Procedure: Stable $\mathrm{SrCl}_{2}$ solution was added to sets of three simulated NGLLLW samples $\left(0.141 \mathrm{mg} \mathrm{Sr} / \mathrm{L}\right.$, traced with $\left.{ }^{85} \mathrm{Sr}\right)$. The samples were mixed for $1 \mathrm{~h}$ on a Labquake shaker and centrifuged for $30 \mathrm{~min}$ at $5000 \mathrm{rcf}$. The ${ }^{85} \mathrm{Sr}$ count rates of the centrifuged solutions were measured. The centrifuged solutions were adjusted to $\mathrm{pH} 8$ with $5.4 \mathrm{M} \mathrm{HCl}$ and mixed for $1 \mathrm{~h}$ on a Labquake shaker and then centrifuged for $30 \mathrm{~min}$ at $5000 \mathrm{rcf}$. The ${ }^{85} \mathrm{Sr}$ count rates of the centrifuged solutions were measured. 
added. The solutions were mixed for $1 \mathrm{~h}$ on a Labquake shaker during the $\mathrm{SrCl}_{2}$ strike before the liquid-solid separation at $\mathrm{pH}$ 13. The cumulative decontamination factors after adjustment of the clarified solutions to $\mathrm{pH} 8$ were 200 to 400 with a strontium addition of $50 \mathrm{ppm}$ or higher. The indicated strontium concentration in the clarified simulated NGLLLW solutions was $4 \mathrm{ppm}$ at $\mathrm{pH} 13$ and $0.2 \mathrm{ppm}$ at $\mathrm{pH} 8$. The solids that formed in the coprecipitation were identified by X-ray diffraction analysis in the ORNL Analytical Chemistry Division as strontianite, $\mathrm{SrCO}_{3}$.

The $\mathrm{SrCl}_{2}$ strike for strontium removal from simulated NGLLLW is most effective at $\mathrm{pH} 13$, but the settling properties of the solids are more favorable at $\mathrm{pH} 11$ or lower. A test was performed to determine the effect on strontium removal of ferric sulfate, which could aid in flocculation of the solids, in conjunction with a $\mathrm{SrCl}_{2}$ strike at $\mathrm{pH} 13$ and at $\mathrm{pH}$ 11. For the tests at $\mathrm{pH} \mathrm{13,} \mathrm{the} \mathrm{SrCl}_{2}$ (50 ppm strontium) and ferric sulfate (25 ppm iron) were added to the simulated NGLLLW and mixed on a Labquake shaker for $1 \mathrm{~h}$. The samples were then centrifuged, and the $\mathrm{pH}$ was adjusted to 8 . For the tests at $\mathrm{pH} 11$, the $\mathrm{SrCl}_{2}$ and the ferric sulfate were added to the NGLLLW at $\mathrm{pH} 13$ before adjustment to $\mathrm{pH} 11$ and mixing for $1 \mathrm{~h}$. All of the solutions were mixed for an additional hour on a Labquake shaker after adjustment to $\mathrm{pH} 8$. The strontium decontamination factor in the $\mathrm{SrCl}_{2}+$ ferric sulfate strike was 84 at $\mathrm{pH} 13$ and 67 at $\mathrm{pH} 11$ (Table 6.1). The cumulative decontamination factor at $\mathrm{pH} 8$ was 1600 if the initial strike was made at $\mathrm{pH} 13$, compared with a decontamination factor of 328 when the initial strike was made at $\mathrm{pH}$ 11. These results show that it is preferable to make the initial strike and liquid-solid separation at $\mathrm{pH} 13$ if the solids can be separated at that $\mathrm{pH}$ level.

The strontium decontamination factor after a strike of simulated NGLLLW with $\mathrm{SrCl}_{2}+$ ferric sulfate was most effective if the liquid-solid separation was made at $\mathrm{pH} 13$ (Fig. 6.2). Decontamination was slightly lower when the separation was made at $\mathrm{pH} 10.5$ or 11 , and much lower when the separation was made below $\mathrm{pH} 10.5$. In these tests, the strontium was added to the NGLLLW at $\mathrm{pH} 13$, and the solutions were mixed for $1 \mathrm{~h}$ with magnetic stirrers. Then $25 \mathrm{ppm}$ iron was added, the $\mathrm{pH}$ was adjusted to the indicated levels, and the samples were centrifuged with no additional mixing. The decontamination factor dropped from 84 when the liquid-solid separation was made at $\mathrm{pH} 13$ to about 75 
ORNL DWG 93H-882

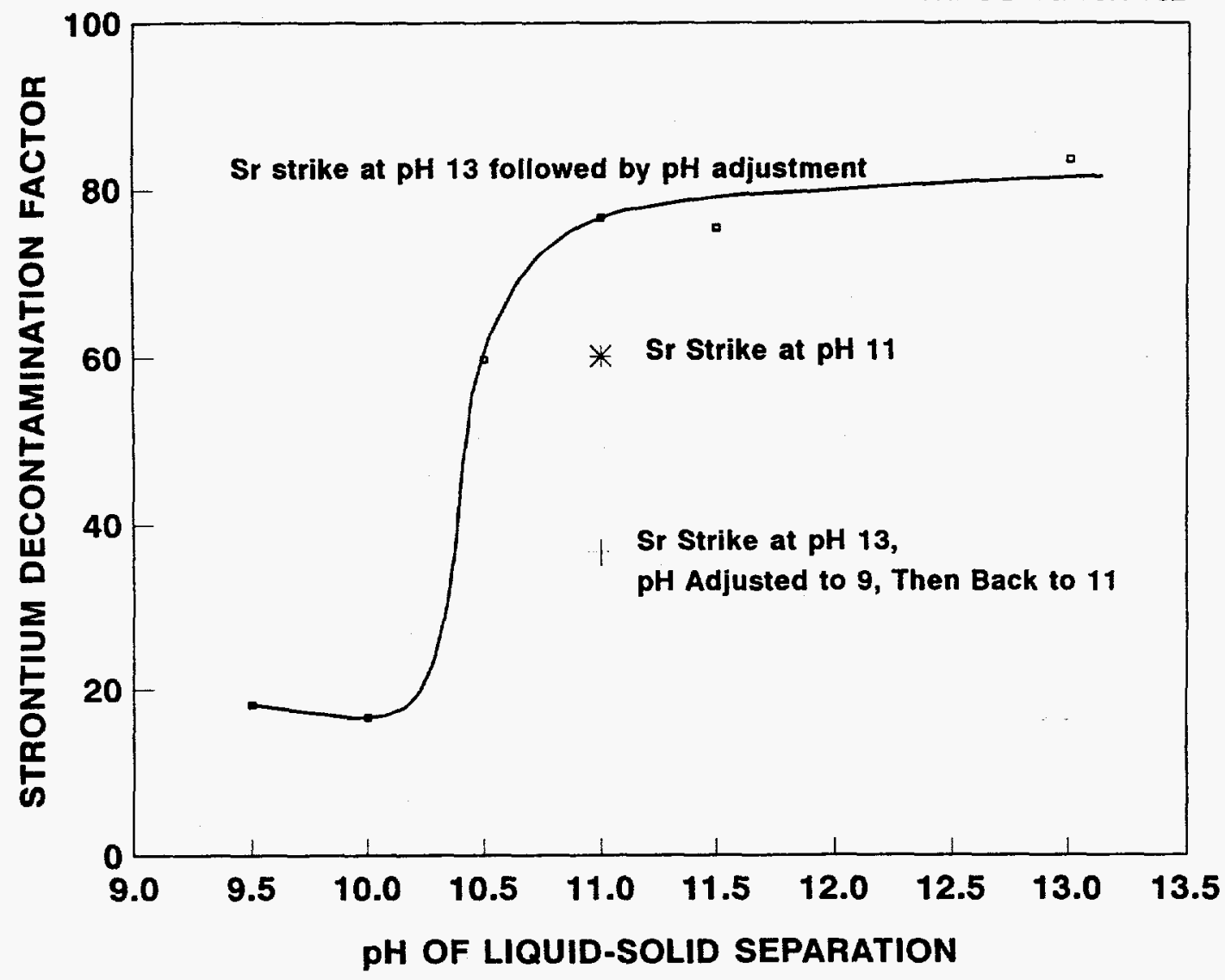

Fig. 6.2. Effect of $\mathrm{pH}$ of liquid-solid separation on ${ }^{85} \mathrm{Sr}$ coprecipitation from simulated newly generated liquid low-level waste (NGLLLW) with stable strontium. Procedure: Sets of three samples of simulated NGLLLW $\left(0.141 \mathrm{mg} \mathrm{Sr} / \mathrm{L}\right.$, traced with $\left.{ }^{85} \mathrm{Sr}\right)$ were mixed for 1 $\mathrm{h}$ with a magnetic stirrer with $50 \mathrm{ppm}$ strontium, added as $\mathrm{SrCl}_{2}$. Ferric sulfate (25 ppm iron) was added to the solutions, and the $\mathrm{pH}$ was adjusted with $5.4 \mathrm{~N} \mathrm{H}_{2} \mathrm{SO}_{4}$ before centrifugation for $30 \mathrm{~min}$ at $5000 \mathrm{rcf}$. The count rates of the centrifuged solutions were measured. The $\mathrm{pH}$ of one sample set was adjusted to $\mathrm{pH} 9$ and then back to 11 with $1 \mathrm{~N} \mathrm{NaOH}$ before centrifugation, and the $\mathrm{pH}$ of one sample set was adjusted to 11 before the $\mathrm{SrCl}_{2}$ strike. 
Table 6.1 Strontium removal from simulated newly generated liquid low-level waste (NGLLLW) with stable strontium

\begin{tabular}{lccc}
\hline & \multicolumn{3}{c}{ Strontium decontamination factor } \\
\cline { 2 - 4 } $\begin{array}{c}\text { Unit } \\
\text { operation }\end{array}$ & $\mathrm{pH}$ & $\begin{array}{c}\text { Unit } \\
\text { operation }\end{array}$ & Cumulative \\
\hline $\begin{array}{c}\mathrm{SrCl}_{2}+\text { ferric sulfate } \\
\text { strike }\end{array}$ & 13 & $83.7 \pm 8.8$ & $83.7 \pm 8.8$ \\
$\mathrm{pH}$ Adjustment & 11 & $2.3 \pm 0.1$ & $186 \pm 9$ \\
$\mathrm{pH}$ Adjustment & 8 & $8.8 \pm 2.2$ & $1636 \pm 379$ \\
& 11 & $67.4 \pm 0.5$ & $67.4 \pm 1.5$ \\
$\mathrm{SrCl}_{2}+$ ferric sulfate & & & $328 \pm 36$ \\
strike & 8 & $4.9 \pm 0.5$ & \\
$\mathrm{pH}$ Adjustment & &
\end{tabular}

aProcedure: Sets of three samples of simulated NGLLLW (0.141 $\mathrm{mg} \mathrm{Sr} / \mathrm{L}$,traced with ${ }^{85} \mathrm{Sr}$ ) at $\mathrm{pH} 13.1$ or $\mathrm{pH} 11$ were mixed for $1 \mathrm{~h}$ on a Labquake shaker with $50 \mathrm{ppm}$ strontium, added as $\mathrm{SrCl}_{2}$ solution, and $25 \mathrm{ppm} \mathrm{Fe}{ }^{3+}$, added as ferric sulfate. The samples were centrifuged for $30 \mathrm{~min}$ at $5000 \mathrm{rcf}$, and the ${ }^{85} \mathrm{Sr}$ count rates of the centrifuged solutions were measured. The centrifuged solutions were adjusted to $\mathrm{pH} 8$ with 5.1 $\mathrm{N} \mathrm{H}_{2} \mathrm{SO}_{4}$, mixed for $1 \mathrm{~h}$ on a Labquake shaker, and centrifuged for $30 \mathrm{~min}$ at $5000 \mathrm{rcf}$. The ${ }^{85} \mathrm{Sr}$ count rates of the centrifuged solutions were measured.

when it was made at $\mathrm{pH} 11.5$ or $\mathrm{pH}$ 11. The decontamination factor dropped further to 60 when the separation was made at $\mathrm{pH} 10.5$ and to 20 when it was made at $\mathrm{pH} 10$ or pH 9.5. In other tests, essentially all of the strontium that coprecipitated with the stable $\mathrm{SrCl}_{2}$ redissolved if the $\mathrm{pH}$ was adjusted to 8 before the liquid-solid separation was made.

The decontamination factor was slightly lower (60 vs 75 ) if both the $\mathrm{SrCl}_{2}$ strike and liquid-solid separation were made at $\mathrm{pH} 11$ than if the $\mathrm{SrCl}_{2}$ strike was made at $\mathrm{pH} 13$ and the liquid-solid separation was made at $\mathrm{pH} 11$. The decontamination factor was only 37 if the $\mathrm{pH}$ was adjusted to 9 and then back to 11 after a $\mathrm{SrCl}_{2}$ strike at $\mathrm{pH} 13$, which indicates that recovery from overshooting during adjustment to $\mathrm{pH} 11$ would be difficult and would result in lower strontium decontamination. 
Extended contact time of the simulated NGLLLW with precipitated strontium did not adversely affect strontium removal. In this test, the mixing time was increased from one-half hour to $20 \mathrm{~h}$ after the addition of $50 \mathrm{ppm}$ strontium $\left(\mathrm{SrCl}_{2}\right)$ and $25 \mathrm{ppm}$ iron (ferric sulfate) at $\mathrm{pH} 11$, followed by a liquid-solid separation and adjustment to $\mathrm{pH} 8$ (Fig. 6.3). In these tests, $\mathrm{SrCl}_{2}$ was added to the simulated NGLLLW at $\mathrm{pH} 13$ and mixed for the indicated times. Ferric sulfate ( $25 \mathrm{ppm}$ iron) was then added, the $\mathrm{pH}$ was adjusted to 11 , and the samples were centrifuged with no additional mixing. The $\mathrm{pH}$ of the clarified solutions was adjusted to 8; the samples were mixed $1 \mathrm{~h}$ on a Labquake shaker and then centrifuged. The decontamination factor in the strike with $\mathrm{SrCl}_{2}+$ ferric sulfate was about 68 , and an additional decontamination factor of slightly less than 5 was measured during $\mathrm{pH}$ adjustment from 11 to 8 . The cumulative decontamination factor was about 330 .

The strength of the $\mathrm{SrCl}_{2}$ solution had no effect on treatment effectiveness. The $\mathrm{SrCl}_{2}$ strike is performed by adding $50 \mathrm{mg} \mathrm{Sr} / \mathrm{L}$ to the simulated NGLLLW and mixing thoroughly. For most of the tests, the $\mathrm{SrCl}_{2}$ solution added to the NGLLLW contained $10,000 \mathrm{ppm}$ strontium, and the volume added in the $\mathrm{SrCl}_{2}$ strike to provide $50 \mathrm{ppm}$ was $0.5 \%$ of the simulated NGLLLW volume. The strontium concentration in the $\mathrm{SrCl}_{2}$ solution and the volume of $\mathrm{SrCl}_{2}$ solution added to the simulated NGLLLW had little effect on the strontium decontamination factor (Fig. 6.4). The strontium decontamination factor was 85 when the volume of $\mathrm{SrCl}_{2}$ strike solution added to $5 \mathrm{~mL}$ of simulated NGLLLW was $0.025 \mathrm{~mL}$ and 94 to 101 when the $\mathrm{SrCl}_{2}$ strike volume was 0.050 to $0.500 \mathrm{~mL}$. The $\mathrm{SrCl}_{2}$ strike was made at $\mathrm{pH} 13$, and the solutions were mixed with magnetic stirrers for $1 \mathrm{~h}$. Then $25 \mathrm{ppm}$ iron (ferric sulfate) was added, and the solutions were mixed an additional hour before centrifugation.

About 80 to $90 \%$ of the strontium, equivalent to a decontamination factor of 5 to 10 , was removed from simulated NGLLLW in the aluminum hydroxide that precipitates during adjustment of the $\mathrm{pH}$ to 8 for cesium removal (Fig. 6.5). The decontamination factor increased to about 90 when the initial aluminum concentration of the simulated NGLLLW was increased to $800 \mathrm{ppm}$ by adding $\mathrm{AlCl}_{3}$ and to about 120 when the initial 
ORNL DWG $93 \mathrm{H}-883$

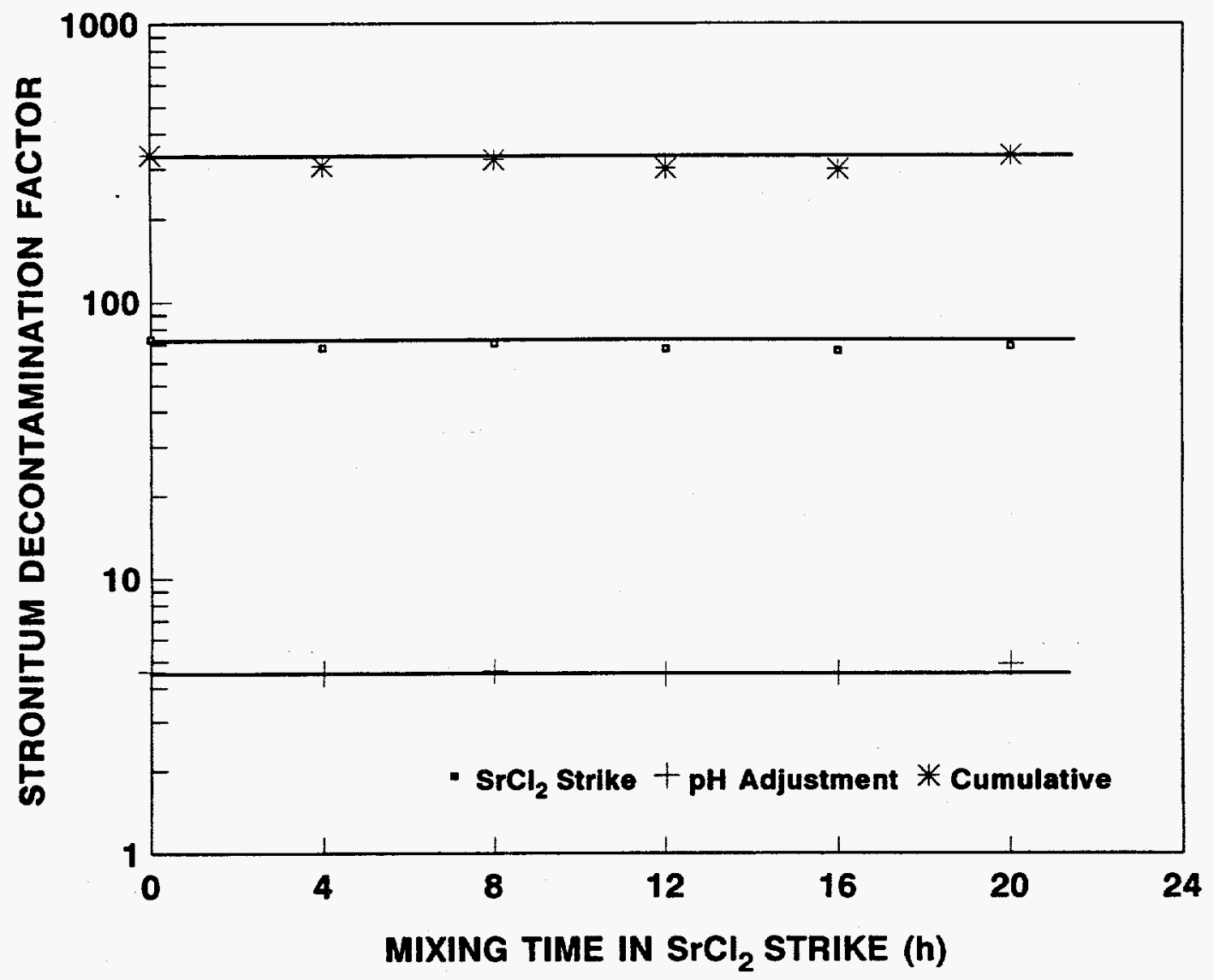

Fig. 6.3. Effect of mixing time on coprecipitation of ${ }^{85} \mathrm{Sr}$ from simulated newly generated liquid low-level waste (NGLLLW) with stable strontium. Procedure: Stable $\mathrm{SrCl}_{2}$ solution ( $50 \mathrm{ppm}$ strontium) was added to sets of three simulated NGLLLW samples $\left(0.141 \mathrm{mg} \mathrm{Sr} / \mathrm{L}\right.$, traced with $\left.{ }^{85} \mathrm{Sr}\right)$ and stirred with a magnetic stirrer. Sample sets were removed from the mixer periodically, ferric sulfate $(25 \mathrm{ppm}$ iron) was added, and the $\mathrm{pH}$ was adjusted to 11 with $5.4 \mathrm{~N} \mathrm{H}_{2} \mathrm{SO}_{4}$. The samples were centrifuged, and the ${ }^{85} \mathrm{Sr}$ count rates of the centrifuged solutions were measured. The centrifuged samples were adjusted to $\mathrm{pH} 8$ with $5.4 \mathrm{~N} \mathrm{H}_{2} \mathrm{SO}_{4}$, mixed for $1 \mathrm{~h}$ on a Labquake shaker, and centrifuged for $30 \mathrm{~min}$ at 5000 rcf. The ${ }^{85} \mathrm{Sr}$ count rates of the centrifuged solutions were measured. 


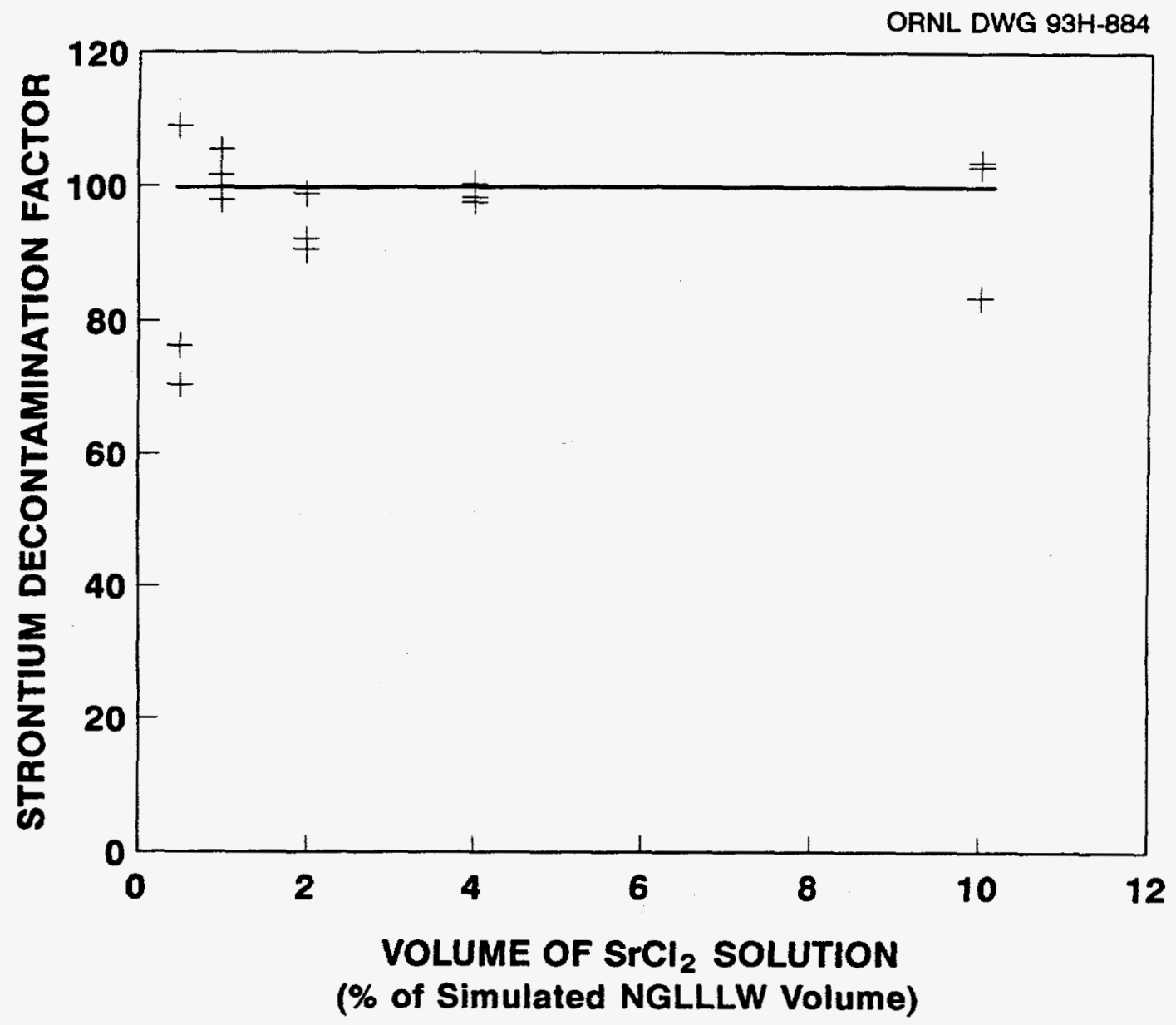

Fig. 6.4. Effect of stable strontium solution volume on coprecipitation of ${ }^{85} \mathrm{Sr}$ from simulated newly generated liquid low-level waste (NGLLLW) with stable strontium. Procedure: Stable strontium (50 ppm, $\mathrm{SrCl}_{2}$ solution) and ferric sulfate (25 ppm iron) were added to sets of three simulated NGLLLW solutions $\left(0.141 \mathrm{mg} \mathrm{Sr} / \mathrm{L}\right.$, traced with $\left.{ }^{85} \mathrm{Sr}\right)$ and mixed for $1 \mathrm{~h}$ with a magnetic stirrer. The samples were centrifuged for $30 \mathrm{~min}$ at $5000 \mathrm{rcf}$, and the ${ }^{85} \mathrm{Sr}$ count rates of the centrifuged solutions were measured. 
ORNL DWG 93H-885

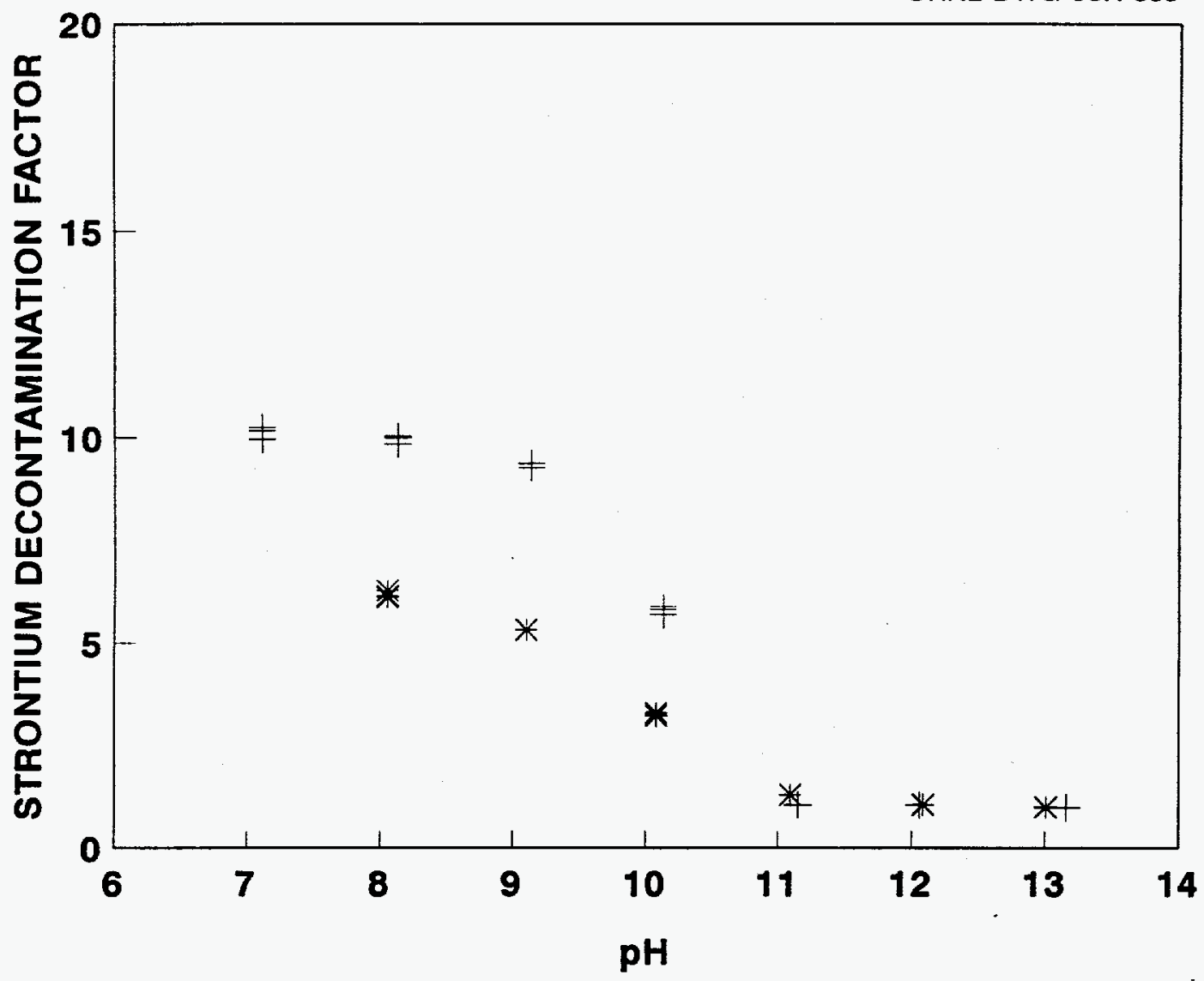

Fig. 6.5. Effect of pH on strontium solubility in simulated newly generated liquid lowlevel waste (NGLLLW). Procedure: The $\mathrm{pH}$ of simulated NGLLLW (0.141 mg Sr/L, traced with ${ }^{85} \mathrm{Sr}$ ) was adjusted with $5.4 \mathrm{~N} \mathrm{HCl}$. The adjusted samples were centrifuged for $30 \mathrm{~min}$ at $5000 \mathrm{rcf}$, and the ${ }^{85} \mathrm{Sr}$ count rates of the centrifuged samples were measured. 
aluminum concentration was $1350 \mathrm{ppm}$ (Fig. 6.6). A sorption isotherm plotted from these results shows a maximum loading on the $\mathrm{Al}(\mathrm{OH})_{3}$ of at least $30 \mathrm{meq} / \mathrm{kg}$ and indicates a sorption ratio for the $\mathrm{Al}(\mathrm{OH})_{3}$ of about 25,000 (Fig. 6.7). This is slightly higher than the sorption ratios measured by Shiao et al. for the distribution of strontium on absorption-grade $\mathrm{Al}_{2} \mathrm{O}_{3}$ from $\mathrm{NaCl}$ solutions. ${ }^{10}$ The strontium decontamination factors were slightly higher when $\mathrm{HCl}$ was used for $\mathrm{pH}$ adjustment than when $\mathrm{H}_{2} \mathrm{SO}_{4}$ was used. Since $\mathrm{H}_{2} \mathrm{SO}_{4}$ is less corrosive and less expensive than $\mathrm{HCl}$, it will probably be the choice for process use. An aluminum concentration of at least $100 \mathrm{ppm}$ is needed to ensure that the cumulative decontamination factor of 80 is achieved (Fig. 6.8). The decontamination factor in the $\mathrm{SrCl}_{2}$ strike with $50 \mathrm{ppm}$ strontium was about 30 regardless of the aluminum concentration of the simulated NGLLLW. The cumulative decontamination factor increased from 30 with no aluminum in the simulated NGLLLW to 72 with $68 \mathrm{ppm}$ aluminum and to 132 with $117 \mathrm{ppm}$ aluminum. The decontamination factor continued to increase with increasing aluminum concentration to 195 with $244 \mathrm{ppm}$ aluminum and to 287 with $335 \mathrm{ppm}$ aluminum. The aluminum concentration anticipated in NGLLLW is 316 ppm.

Strontium was effectively removed from simulated NGLLLW that was mixed with up to $50 \%$ simulated MVST supernate by a $\mathrm{SrCl}_{2}+$ ferric sulfate strike at $\mathrm{pH} 13$ (Fig. 6.9). The strontium decontamination factor decreased by about $0.5 \%$ for each $1 \%$ of simulated supernate in the blend. However, because of the low strontium concentration in the supernate $\left(1.5 \times 10^{-8} \mathrm{~mol} / \mathrm{L}\right)$, the needed decontamination factor decreased at about the same rate as the measured decontamination factor and the measured decontamination factor remained well above the needed decontamination factor. For these tests, triplicate samples of NGLLLW-supernate blends were mixed for $1 \mathrm{~h}$ with $50 \mathrm{ppm}$ strontium $\left(\mathrm{SrCl}_{2}\right)$ and $25 \mathrm{ppm}$ iron (ferric sulfate). The samples were centrifuged for $30 \mathrm{~min}$ at $5000 \mathrm{rcf}$, and aliquots of the centrifuged solutions were counted.

\subsection{Strontium Removal by Coprecipitation with Stable Ca Salts}

Strontium was also removed from simulated NGLLLW by coprecipitation with calcium salts, but less effectively than with stable strontium salts. Strontium 


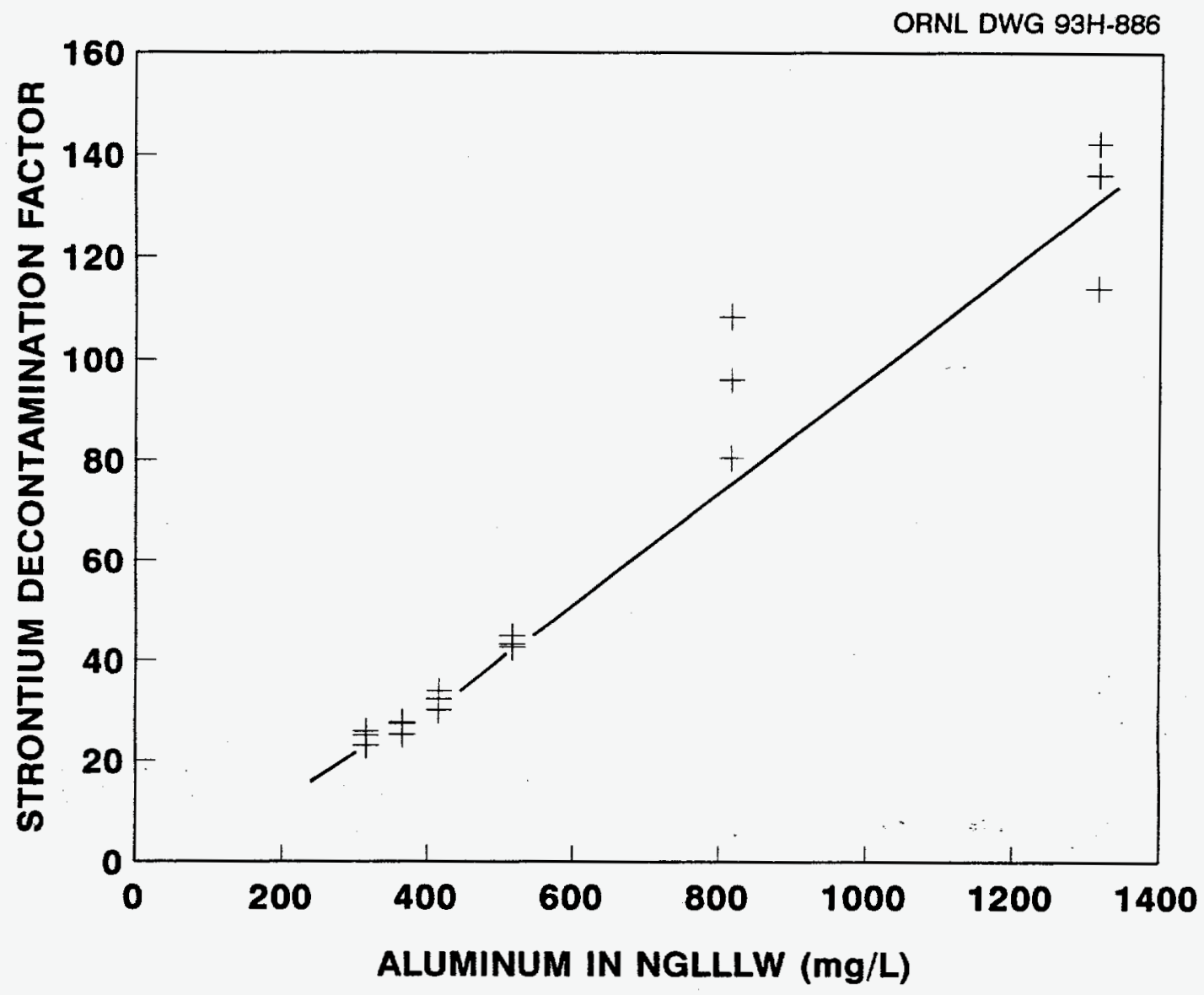

Fig. 6.6. Effect of aluminum concentration in simulated newly generated liquid lowlevel waste (NGLLLW) on strontium precipitation during $\mathrm{pH}$ adjustment. Procedure: $\mathrm{AlCl}_{3}$ solution was added to sets of three simulated NGLLLW samples $(0.141 \mathrm{mg} \mathrm{Sr} / \mathrm{L}$, traced with ${ }^{85} \mathrm{Sr}$ ), and the samples were adjusted to $\mathrm{pH} 8$ with $5.4 \mathrm{~N} \mathrm{HCl}$. The adjusted samples were mixed for $1 \mathrm{~h}$ on a Labquake shaker and centrifuged for $30 \mathrm{~min}$ at $5000 \mathrm{rcf}$. The ${ }^{85} \mathrm{Sr}$ count rates of the centrifuged samples were measured. 


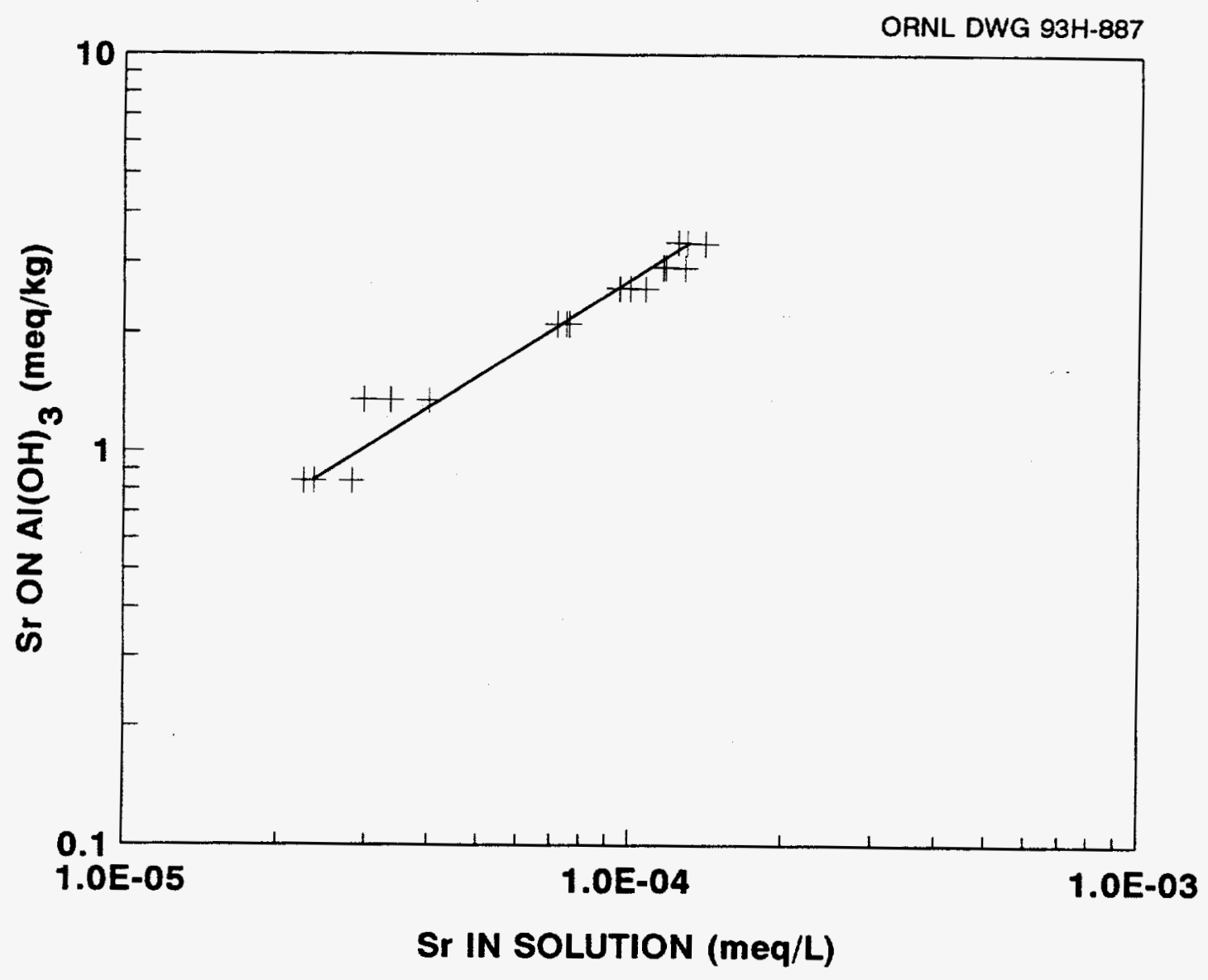

Fig. 6.7. Isotherm for strontium sorption from simulated newly generated liquid lowlevel waste (NGLLLW) on $\mathrm{Al}(\mathrm{OH})_{3}$. Procedure: $\mathrm{AlCl}_{3}$ solution was added to sets of three simulated NGLLLW samples $\left(0.141 \mathrm{mg} \mathrm{Sr} / \mathrm{L}\right.$, traced with $\left.{ }^{85} \mathrm{Sr}\right)$, and the samples were adjusted to $\mathrm{pH} 8$ with $5.4 \mathrm{~N} \mathrm{HCl}$. The adjusted samples were mixed for $1 \mathrm{~h}$ on a Labquake shaker and centrifuged for $30 \mathrm{~min}$ at $5000 \mathrm{rcf}$. The ${ }^{85} \mathrm{Sr}$ count rates of the centrifuged samples were measured. 


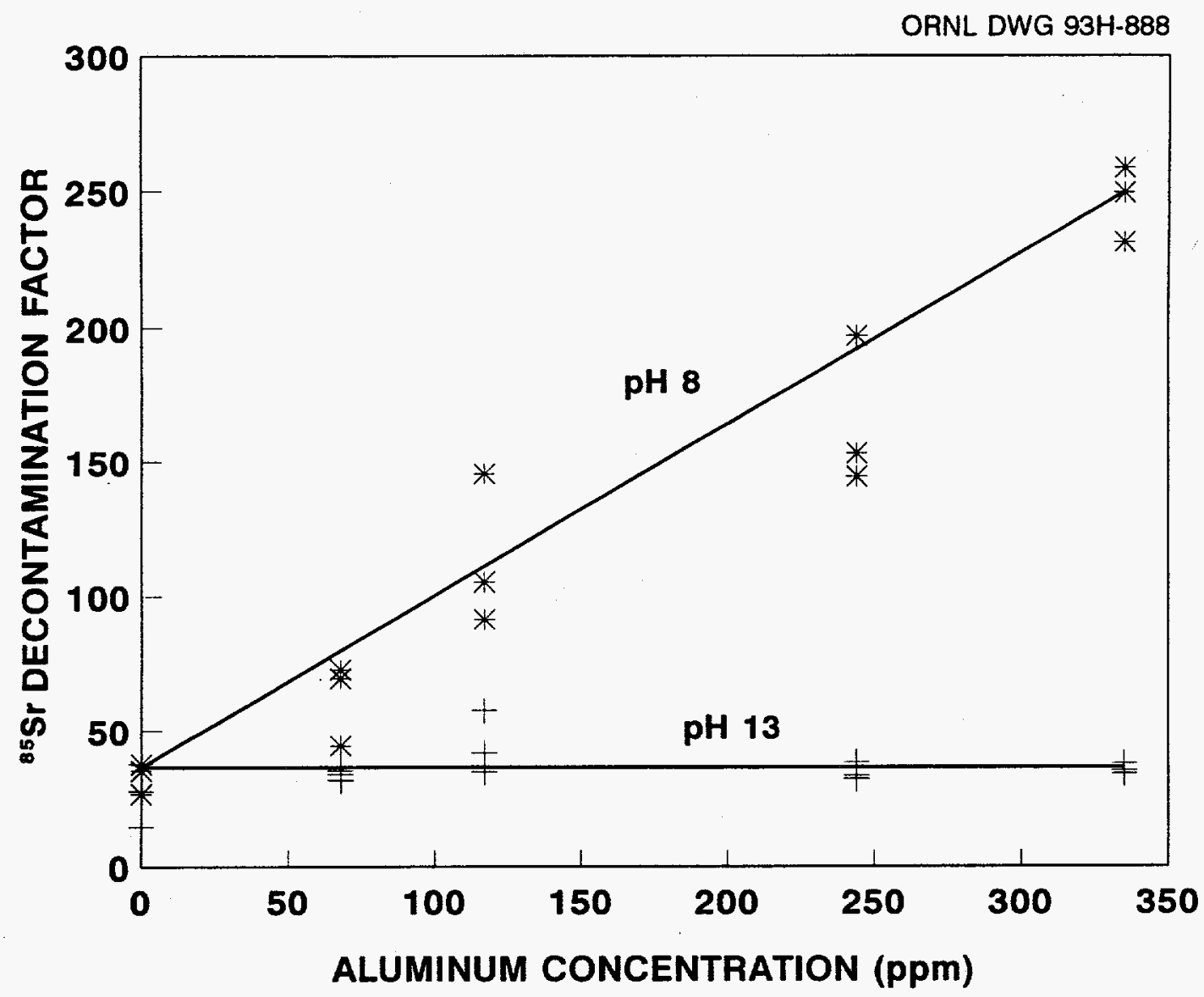

Fig. 6.8. Effect of aluminum concentration on ${ }^{85} \mathrm{Sr}$ removal from simulated newly generated liquid low-level waste (NGLLLW) with stable strontium. Procedure: The aluminum concentrations of sets of three simulated NGLLLW samples $\left(0.141 \mathrm{mg} \mathrm{Sr} / \mathrm{L}\right.$, traced with $\left.{ }^{85} \mathrm{Sr}\right)$ were varied by adding aluminum foil dissolved in $\mathrm{NaOH}$. The sample sets were mixed for $1 \mathrm{~h}$ on a Labquake shaker with $50 \mathrm{ppm}$ stable strontium added as $\mathrm{SrCl}_{2}$ solution. The samples were centrifuged for $30 \mathrm{~min}$ at $5000 \mathrm{rcf}$, and the ${ }^{85} \mathrm{Sr}$ count rates of the centrifuged solutions were measured. The centrifuged solutions were adjusted to $\mathrm{pH} 8$ with $5.1 \mathrm{~N} \mathrm{H}_{2} \mathrm{SO}_{4}$, mixed for $1 \mathrm{~h}$ on a Labquake shaker, and centrifuged for $30 \mathrm{~min}$ at $5000 \mathrm{rcf}$. The ${ }^{85} \mathrm{Sr}$ count rates of the centrifuged solutions were measured. 


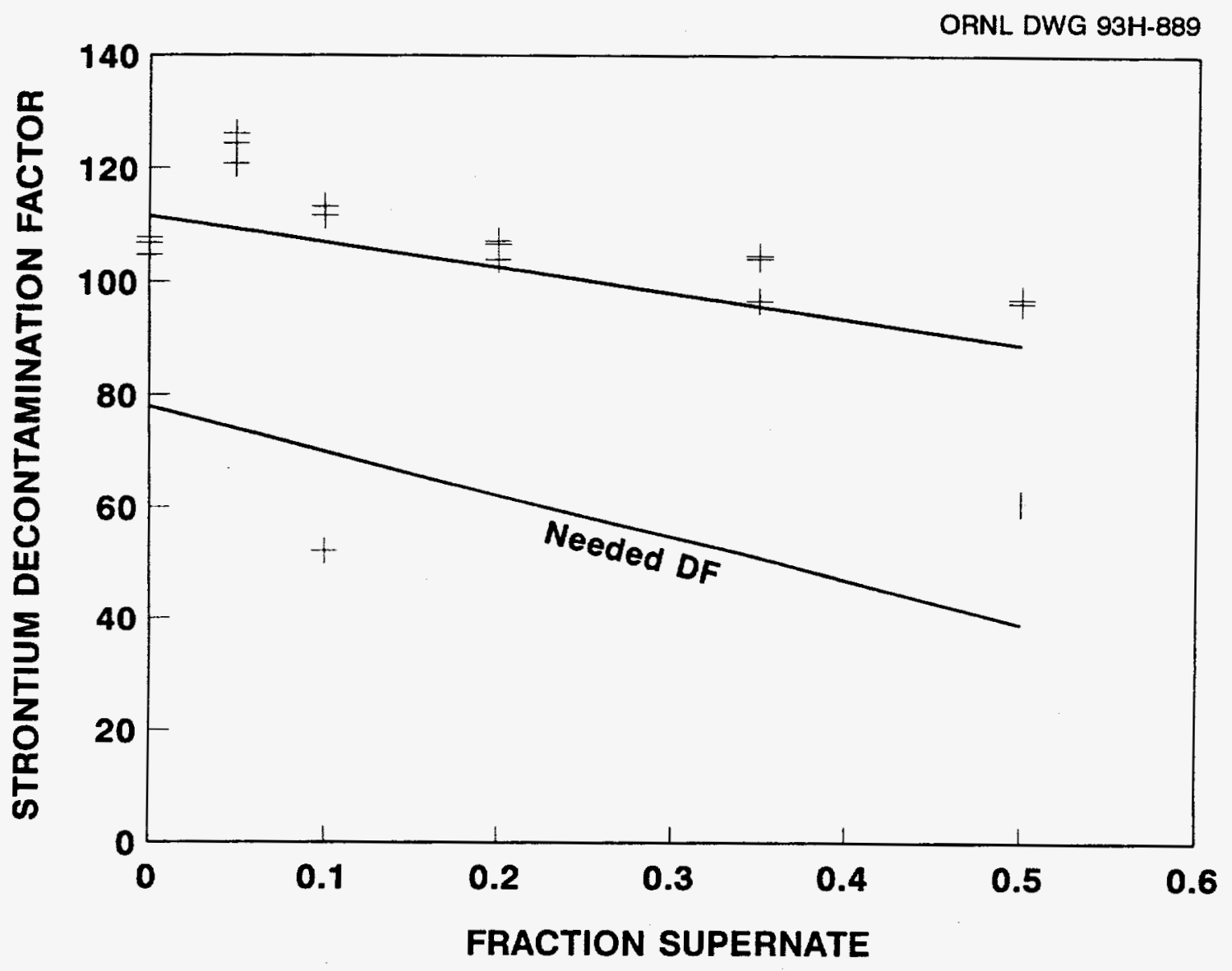

Fig. 6.9. Strontium removal from mixtures of simulated newly generated liquid lowlevel waste (NGLLLW) and simulated Melton Valley Storage Tank (MVST) supernate with $\mathrm{SrCl}_{2}+$ ferric sulfate. Procedure: Sets of three samples of mixtures of simulated NGLLLW $(0.141 \mathrm{mg} \mathrm{Sr} / \mathrm{L}, 1.16 \mathrm{mg} \mathrm{Cs} / \mathrm{L}$, and $0.0337 \mathrm{mg} \mathrm{Ru} / \mathrm{L}$ ) and simulated MVST supernate $(0.0013 \mathrm{mg} \mathrm{Sr} / \mathrm{L})$ were traced with ${ }^{85} \mathrm{Sr}$ and mixed for $1 \mathrm{~h}$ on magnetic stirrers with $50 \mathrm{ppm}$ strontium $\left(\mathrm{SrCl}_{2}\right)$ and $25 \mathrm{ppm}$ iron (ferric sulfate). The samples were centrifuged for $30 \mathrm{~min}$ at $5000 \mathrm{rcf}$, and the ${ }^{85} \mathrm{Sr}$ count rates of the centrifuged solutions were measured. 
decontamination factors high enough to allow discharge of the treated waste to the PWTP at ORNL were obtained by two strikes with $80 \mathrm{ppm}$ calcium at $\mathrm{pH} 13$, with a liquid-solid separation after each strike, followed by adjustment of the $\mathrm{pH}$ to 8 (Table 6.2). The cumulative strontium decontamination factor was 3.2 after the first $\mathrm{CaCl}_{2}$ strike, 10.4 after the second, and 164 after $\mathrm{pH}$ adjustment. Adding $80 \mathrm{ppm}$ iron (ferric sulfate) in the second $\mathrm{CaCl}_{2}$ strike approximately doubled the decontamination factors after the second $\mathrm{CaCl}_{2}$ strike and after $\mathrm{pH}$ adjustment. As with strontium coprecipitation, additional decontamination occurred during adjustment to $\mathrm{pH} 8$ before treatment to remove cesium.

Table 6.2. Strontium removal from simulated newly generated liquid low-level waste (NGLLLW) with stable calcium

\begin{tabular}{llcc}
\hline Strike & \multicolumn{1}{c}{ Treatment } & $\mathrm{pH}$ & $\begin{array}{c}\text { Cumulative strontium } \\
\text { decontamination factor }\end{array}$ \\
\hline First & $\mathrm{CaCl}_{2}$ & 13 & $3.2 \pm 0.02$ \\
Second & $\mathrm{CaCl}_{2}$ & 13 & $10.4 \pm 0.55$ \\
& $\mathrm{pH} \mathrm{Adjustment}$ & 8 & $164 \pm 8.2$ \\
& & & \\
\multirow{2}{*}{ Second } & $\mathrm{CaCl}_{2}+$ ferric sulfate & 13 & $23.0 \pm 2.3$ \\
& $\mathrm{pH} \mathrm{Adjustment}$ & 8 & $389 \pm 47$ \\
\hline
\end{tabular}

"Procedure: Simulated NGLLLW $\left(0.141 \mathrm{mg} \mathrm{Sr} / \mathrm{L}\right.$, traced with $\left.{ }^{85} \mathrm{Sr}\right)$ was mixed for $1 \mathrm{~h}$ with a magnetic stirrer with $80 \mathrm{ppm}$ calcium, added as $\mathrm{CaCl}_{2}$. The sample was centrifuged for $30 \mathrm{~min}$ at $5000 \mathrm{rcf}$, and the ${ }^{85} \mathrm{Sr}$ count rates of three aliquots of the centrifuged solution were measured. Sets of three samples of the centrifuged solution were mixed for $1 \mathrm{~h}$ on a Labquake shaker with $80 \mathrm{ppm}$ calcium, as $\mathrm{CaCl}_{2}$ and $80 \mathrm{ppm} \mathrm{Fe}{ }^{3+}$, as ferric sulfate, and centrifuged for $30 \mathrm{~min}$ at $5000 \mathrm{rcf}$. The ${ }^{85} \mathrm{Sr}$ count rates of the centrifuged solutions were measured. The centrifuged solutions were adjusted to $\mathrm{pH} 8$ with $5.4 \mathrm{~N} \mathrm{HCl}$, mixed for $1 \mathrm{~h}$ on a Labquake shaker, and centrifuged for $30 \mathrm{~min}$ at $5000 \mathrm{rcf}$. The ${ }^{85} \mathrm{Sr}$ count rates of the centrifuged solutions were measured.

A cumulative strontium decontamination factor of about 20 was obtained by adding $80 \mathrm{ppm}$ calcium (as $\mathrm{CaCl}_{2}$ ) to simulated NGLLLW, making a liquid-solid separation at $\mathrm{pH}$ 13, and adjusting the $\mathrm{pH}$ to 8 (Fig. 6.10). The decontamination factor 


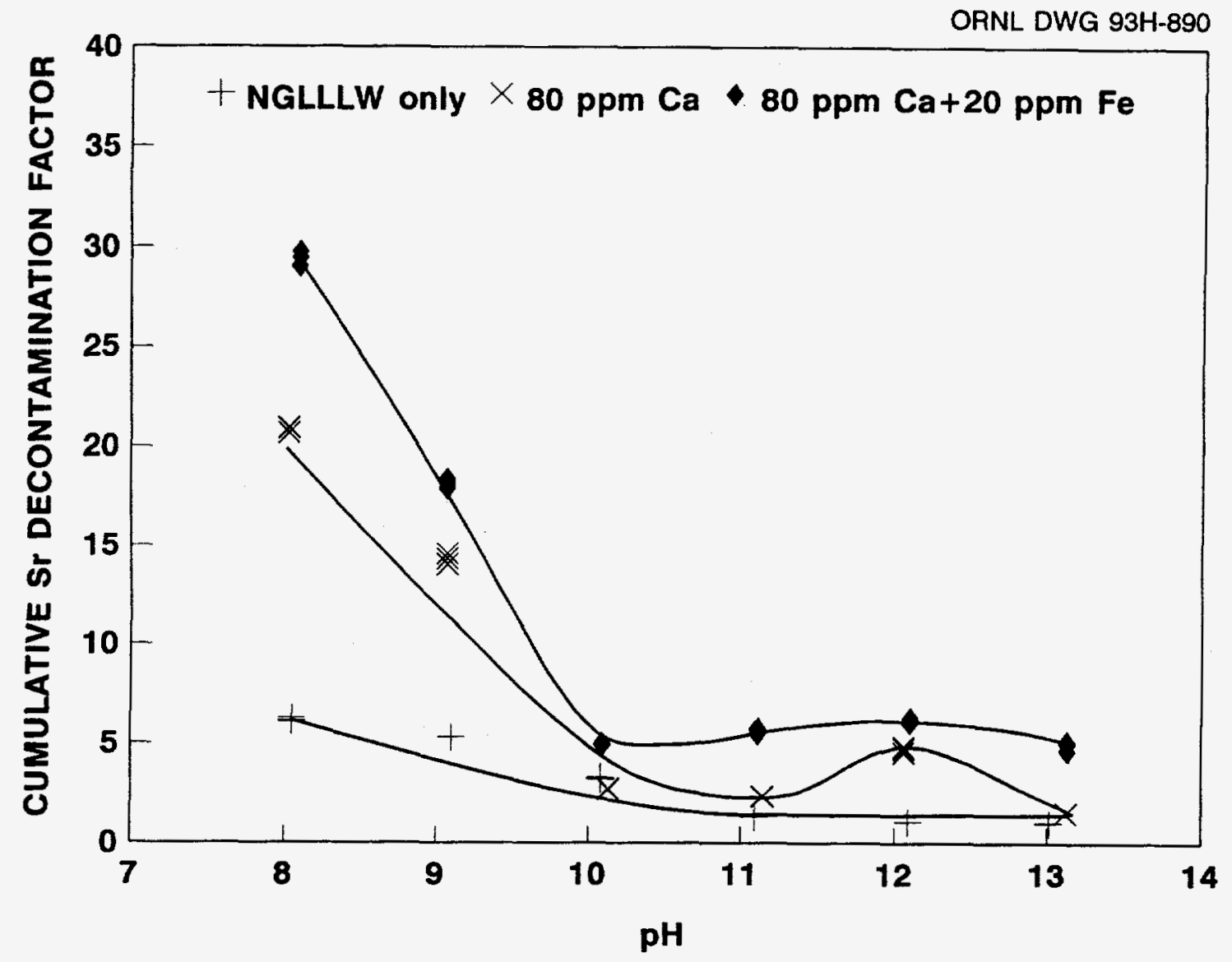

Fig. 6.10. Effect of $\mathrm{pH}$ on strontium coprecipitation from simulated newly generated liquid low-level waste (NGLLLW) with stable calcium. Procedure: Simulated NGLLLW $\left(0.141 \mathrm{mg} \mathrm{Sr} / \mathrm{L}\right.$, traced with $\left.{ }^{85} \mathrm{Sr}\right)$ was mixed for $1 \mathrm{~h}$ on a Labquake shaker with $80 \mathrm{ppm}$ stable calcium, added as $\mathrm{CaCl}_{2}$ solution, and $25 \mathrm{ppm} \mathrm{Fe}{ }^{3+}$, added as ferric sulfate. The $\mathrm{pH}$ of sets of three samples was adjusted with $5.4 \mathrm{~N} \mathrm{HCl}$, the samples were centrifuged for $30 \mathrm{~min}$ at $5000 \mathrm{rcf}$, and the ${ }^{85} \mathrm{Sr}$ count rates of the centrifuged samples were measured. 
from $\mathrm{pH}$ adjustment alone was about 5. The addition of $20 \mathrm{ppm}$ iron (ferric sulfate) with the calcium at $\mathrm{pH} 13$ increased the decontamination factor to about 30 . Increasing the calcium concentration above $80 \mathrm{ppm}$ had little effect on the decontamination factor (Fig. 6.11). The strontium decontamination factor was only slightly affected by the amount of iron when $20 \mathrm{ppm}$ calcium and varying amounts of ferric sulfate were added to simulated NGLLLW prepared with process water at pH 13 (Fig. 6.12). A liquid-solid separation was made at $\mathrm{pH} 13$, and the $\mathrm{pH}$ was adjusted to $\mathrm{pH} 8$. The strontium decontamination factor increased from about 16 with no iron present to 23 with $80 \mathrm{ppm}$ iron and to 27 with $200 \mathrm{ppm}$ iron.

A liquid-solid separation after coprecipitation with $\mathrm{CaCl}_{2}$ and ferric sulfate is necessary before adjustment of the $\mathrm{pH}$ to 8 . When simulated NGLLLW was treated with $20 \mathrm{ppm}$ calcium and $20 \mathrm{ppm}$ iron and adjusted to $\mathrm{pH} 8$ before the liquid-solid separation, the decontamination factor decreased from 13.1 after one-half hour of mixing at $\mathrm{pH} 8$ to 12.6 after $1 \mathrm{~h}, 6.4$ after $25 \mathrm{~h}$, and 7.4 after $96 \mathrm{~h}$ (Fig. 6.13). The decontamination factors after $24 \mathrm{~h}$ or longer are about the same as those for $\mathrm{pH}$ adjustment alone.

\subsection{Strontium Removal with Sodium Titanate}

The preparation and strontium sorption properties of sodium titanate have been extensively studied by Dosch et al. at Sandia National Laboratories, ${ }^{11}$ and the use of sodium titanate for strontium removal from alkaline waste solutions has been studied at ORNL and elsewhere. ${ }^{2.12}$ The use of sodium titanate, in conjunction with adjustment to $\mathrm{pH} 8$, provided strontium decontamination from simulated NGLLLW in our tests that was high enough to allow discharge to the PWTP. However, we found inconsistencies in performance with sodium titanate from different suppliers and in different batches from the same supplier. Some materials were much less effective than others. In addition, even small concentrations of calcium in simulated NGLLLW severely depressed strontium sorption with sodium titanate. These results, coupled with the effectiveness and simplicity of strontium coprecipitation from simulated NGLLLW with stable strontium or calcium salts, make coprecipitation a more desirable processing method for strontium removal from simulated NGLLLW. 
ORNL DWG 93H-891

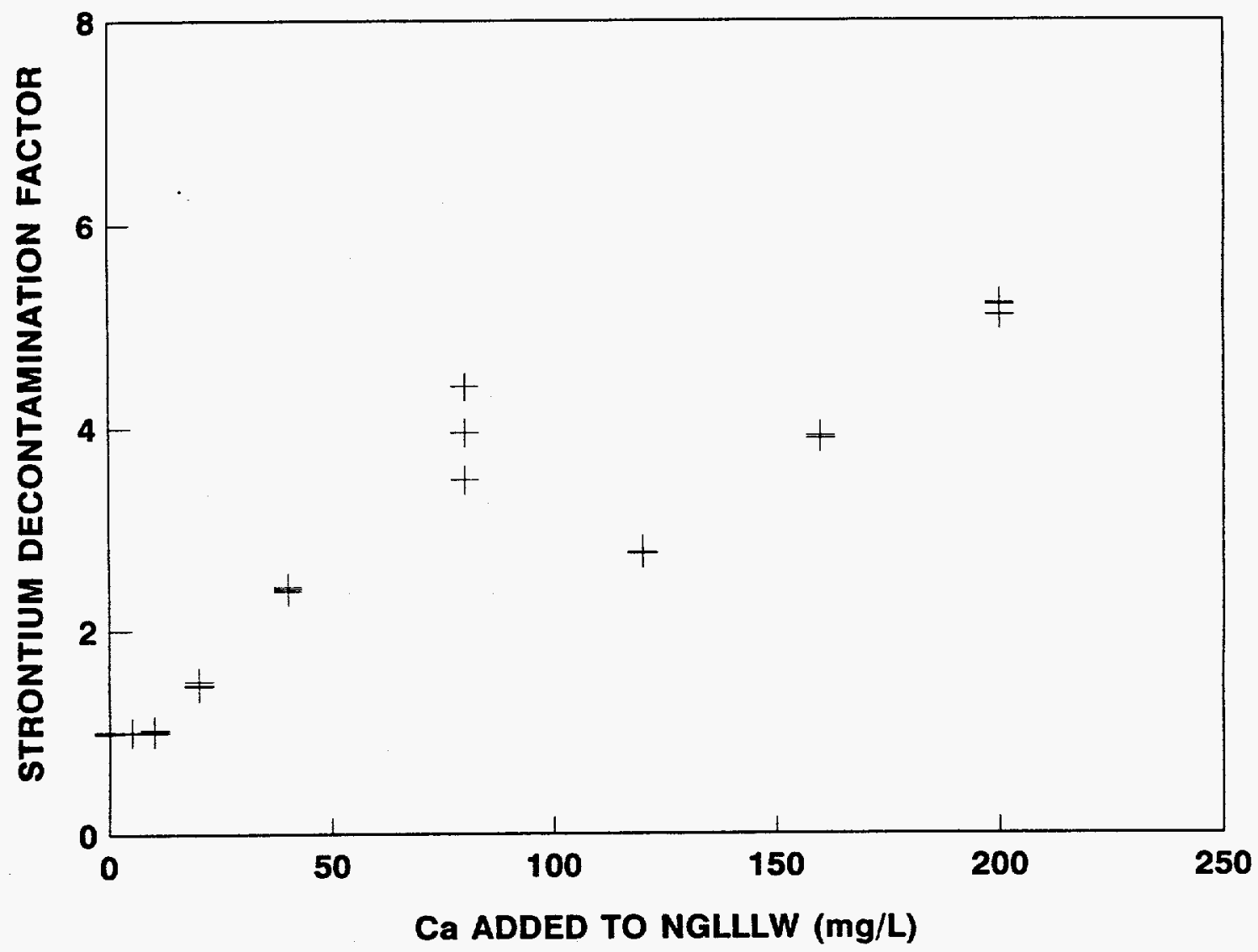

Fig. 6.11. Effect of calcium addition on strontium coprecipitation from simulated newly generated liquid low-level waste (NGLLLW) with stable calcium Procedure: Simulated NGLLLW $\left(0.141 \mathrm{mg} \mathrm{Sr} / \mathrm{L}\right.$, traced with ${ }^{85} \mathrm{Sr}$ ) was mixed with $\mathrm{CaCl}_{2}$ solution for $1 \mathrm{~h}$ on a Labquake shaker. The solutions were centrifuged for $30 \mathrm{~min}$ at $5000 \mathrm{rcf}$, and the ${ }^{85} \mathrm{Sr}$ count rates of the centrifuged solutions were measured. 


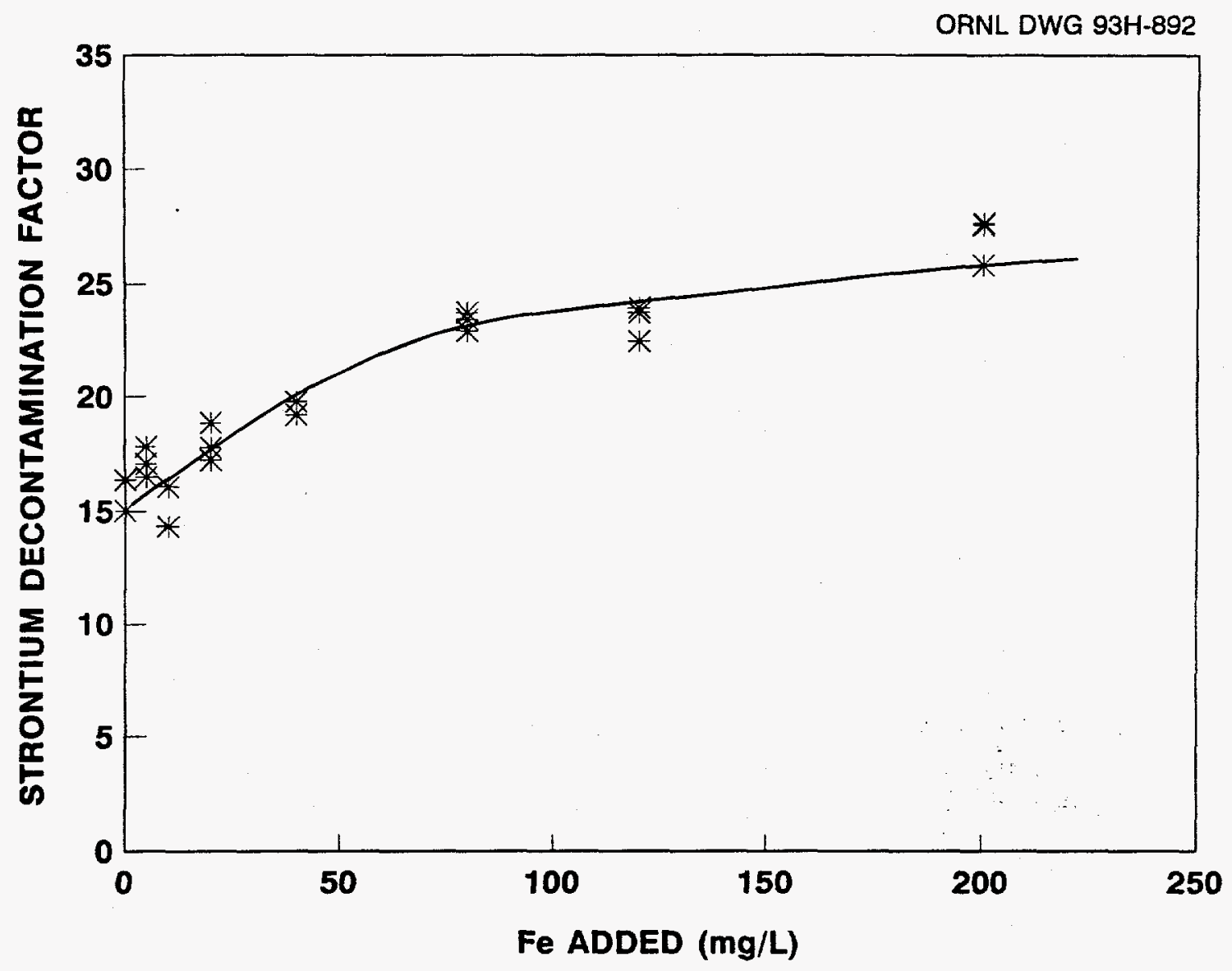

Fig. 6.12 Effect of ferric sulfate on strontium coprecipitation with stable calcium. Procedure: Sets of three samples of simulated newly generated liquid low-level waste $\left(0.141 \mathrm{mg} \mathrm{Sr} / \mathrm{L}\right.$, traced with ${ }^{85} \mathrm{Sr}$ ) were mixed for $1 \mathrm{~h}$ on a Labquake shaker with ferric sulfate. The samples were centrifuged, and the ${ }^{85} \mathrm{Sr}$ count rates of the centrifuged samples were measured. 


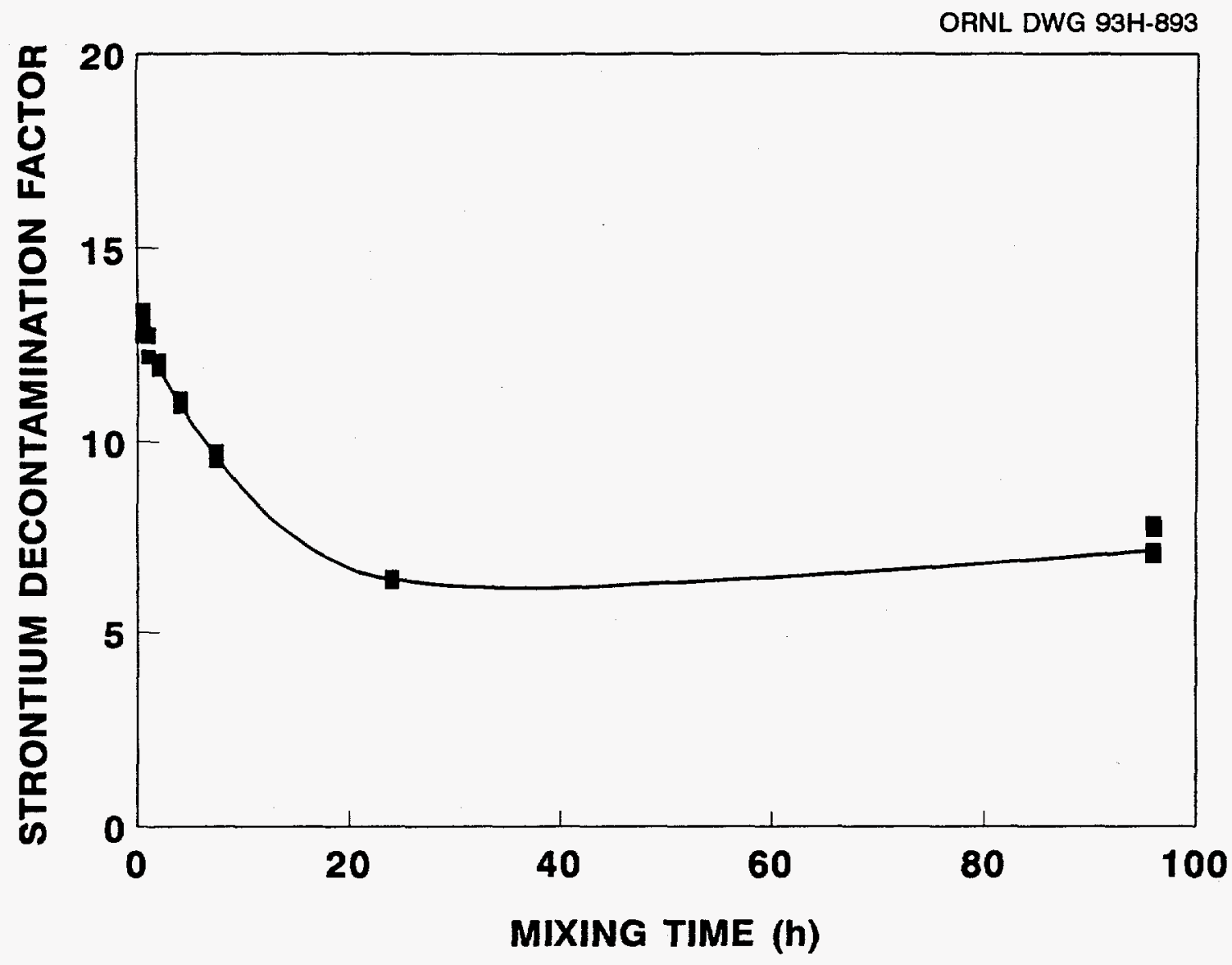

Fig. 6.13. Effect of mixing time on strontium coprecipitation with stable calcium. Procedure: Simulated newly generated liquid low-level waste $\left(0.141 \mathrm{mgSr} / \mathrm{L}\right.$, traced with $\left.{ }^{85} \mathrm{Sr}\right)$ was mixed with $20 \mathrm{ppm}$ calcium, added as $\mathrm{CaCl}_{2}$ solution, and the $\mathrm{pH}$ was adjusted to 8 with $5.4 \mathrm{~N} \mathrm{HCl}$. Sets of three samples of the adjusted solution were mixed for $1 \mathrm{~h}$ on a Labquake shaker with $20 \mathrm{ppm} \mathrm{Fe}^{3+}$, added as ferric sulfate. Sample sets were removed from the shaker as a function of time and centrifuged for $30 \mathrm{~min}$ at $5000 \mathrm{rcf}$. The ${ }^{85} \mathrm{Sr}$ count rates of the centrifuged samples were measured. 
Six sodium titanate samples were tested for strontium removal from simulated NGLLLW. Most of the sorption measurements were made with pellets prepared by Norton Company from sodium titanate prepared by Cerac, Inc., to Sandia specifications. The pellets were ground and sized before use in the sorption tests. Two batches of sodium titanate powder obtained from Cerac, Inc, several years apart were also tested, along with sodium titanate powder obtained by D. O. Campbell from R. G. Dosch at Sandia National Laboratories; sodium titanate powder from Tam Ceramics, Inc.; and a sodium titanate slurry prepared by Boulder Scientific Company. Since sodium titanate is most effective for treating strongly alkaline solutions, most of the sorption measurements were made with unadjusted simulated NGLLLW at pH 13.1.

The maximum strontium sorption from simulated NGLLLW with 20 to 50 mesh sodium titanate prepared from the pellets occurred at $\mathrm{pH} 13.1$ (Fig. 6.14). A maximum strontium decontamination factor of about 20 was measured when $500 \mathrm{ppm}$ sodium titanate was contacted with unadjusted simulated NGLLLW. The decontamination factor dropped to about 1.5 at $\mathrm{pH} 11$ and then increased to slightly more than 5 as the $\mathrm{pH}$ was lowered to 8. The increase at the lower $\mathrm{pH}$ levels was due to strontium sorption on the $\mathrm{Al}(\mathrm{OH})_{3}$ precipitate. A cumulative strontium decontamination factor of about 150 to 200 could be obtained by sorption on the sodium titanate at $\mathrm{pH} 13$ followed by a liquid-solid separation at $\mathrm{pH} 13$ and adjustment of the $\mathrm{pH}$ to 8 . The liquid-solid separation at $\mathrm{pH} 13$ would be required because the strontium rapidly goes back into solution if the $\mathrm{pH}$ is lowered (Fig. 6.15). The strontium decontamination factor from simulated NGLLLW at pH 13.1 with $500 \mathrm{ppm}$ of 100 to 325 mesh sodium titanate decreased from 134 at $\mathrm{pH} 13.1$ to $\mathbf{4 5}$ when the sodium titanate was left in contact with the solution and the $\mathrm{pH}$ was adjusted to 8 . The $\mathrm{pH}$ adjustment required $35 \mathrm{~min}$. The decontamination factor dropped to 40 after $1 \mathrm{~h}$ at $\mathrm{pH} 8$ and to 30 after $2 \mathrm{~h}$ at $\mathrm{pH} 8$.

Strontium sorption was more effective and also more rapid on 100 to 325 mesh sodium titanate than on 20 to 50 mesh material (Fig. 6.16). Strontium sorption was measured at $\mathrm{pH} 13.1$ with $500 \mathrm{ppm}$ of sodium titanate from the Norton pellets that had 


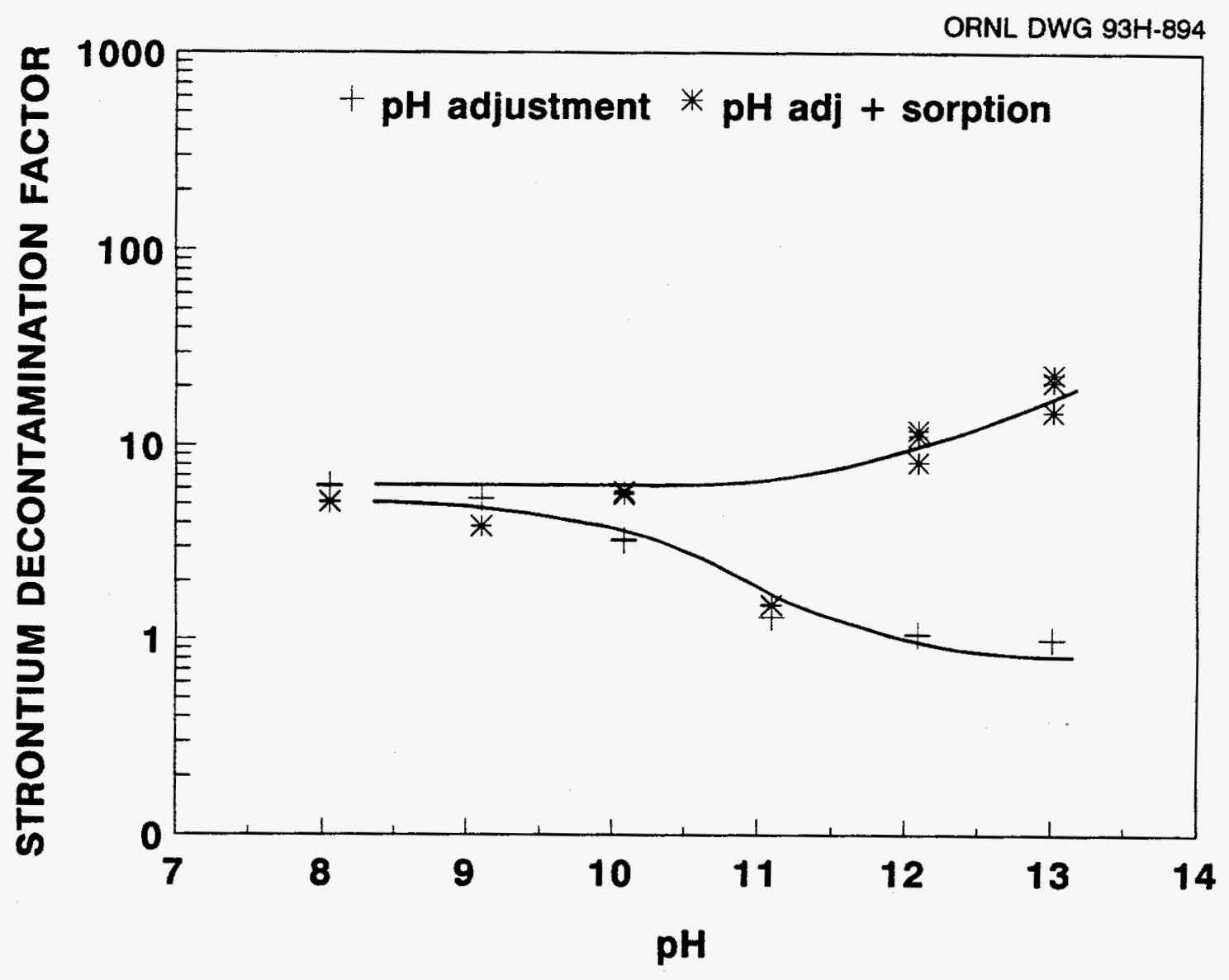

Fig. 6.14. Effect of $\mathrm{pH}$ on strontium sorption from simulated newly generated liquid low-level waste (NGLLLW) on sodium titanate. Procedure: Sets of three samples of simulated NGLLLW $\left(0.141 \mathrm{mg} \mathrm{Sr} / \mathrm{L}\right.$, traced with $\left.{ }^{85} \mathrm{Sr}\right)$ were mixed for $20 \mathrm{~b}$ on a Labquake shaker with 20 to 50 mesh sodium titanate. The samples were centrifuged for $30 \mathrm{~min}$ at $5000 \mathrm{rcf}$, and the ${ }^{85} \mathrm{Sr}$ count rates of the centrifuged samples were measured. The centrifuged samples were adjusted to $\mathrm{pH} 8$ with $5.4 \mathrm{~N} \mathrm{HCl}$ and centrifuged for $30 \mathrm{~min}$ at $5000 \mathrm{rcf}$. The ${ }^{85} \mathrm{Sr}$ count rates of the centrifuged samples were measured. 


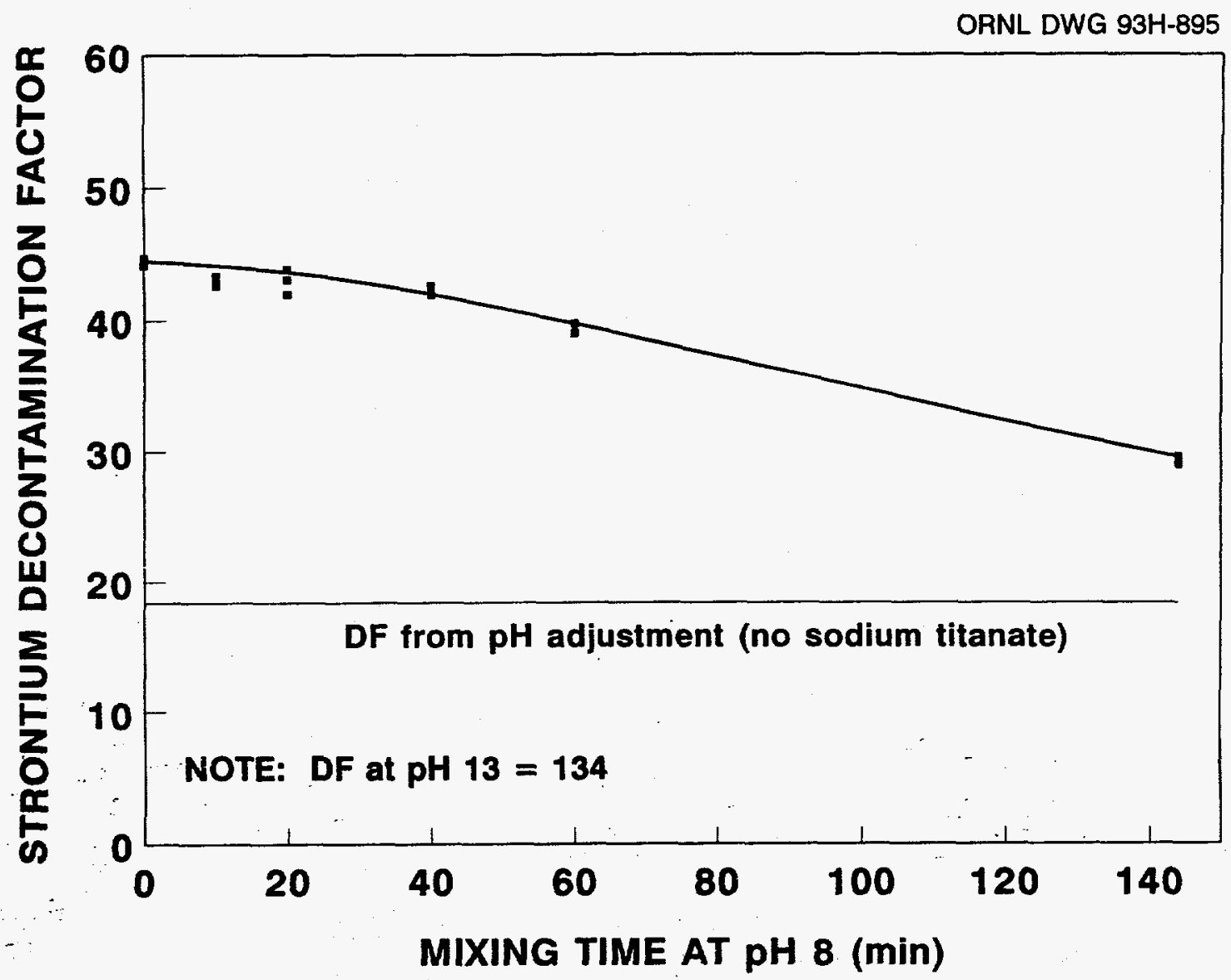

Fig. 6.15. Effect of mixing time at pH 8 on strontium retention on sodium titanate. Procedure: Simulated newly generated liquid low-level waste $\left(0.141 \mathrm{mg} \mathrm{Sr} / \mathrm{L}\right.$, traced with $\left.{ }^{85} \mathrm{Sr}\right)$ was mixed for $20 \mathrm{~h}$ with a magnetic stirrer with $500 \mathrm{ppm} 100$ to 325 mesh sodium titanate. The slurry was adjusted to $\mathrm{pH} 8$ with $5.4 \mathrm{~N} \mathrm{HCl}$, and aliquots of the stirred slurry were taken as a function of time and centrifuged for $30 \mathrm{~min}$ at $5000 \mathrm{rcf}$. The ${ }^{85} \mathrm{Sr}$ count rates of the centrifuged samples were measured. 


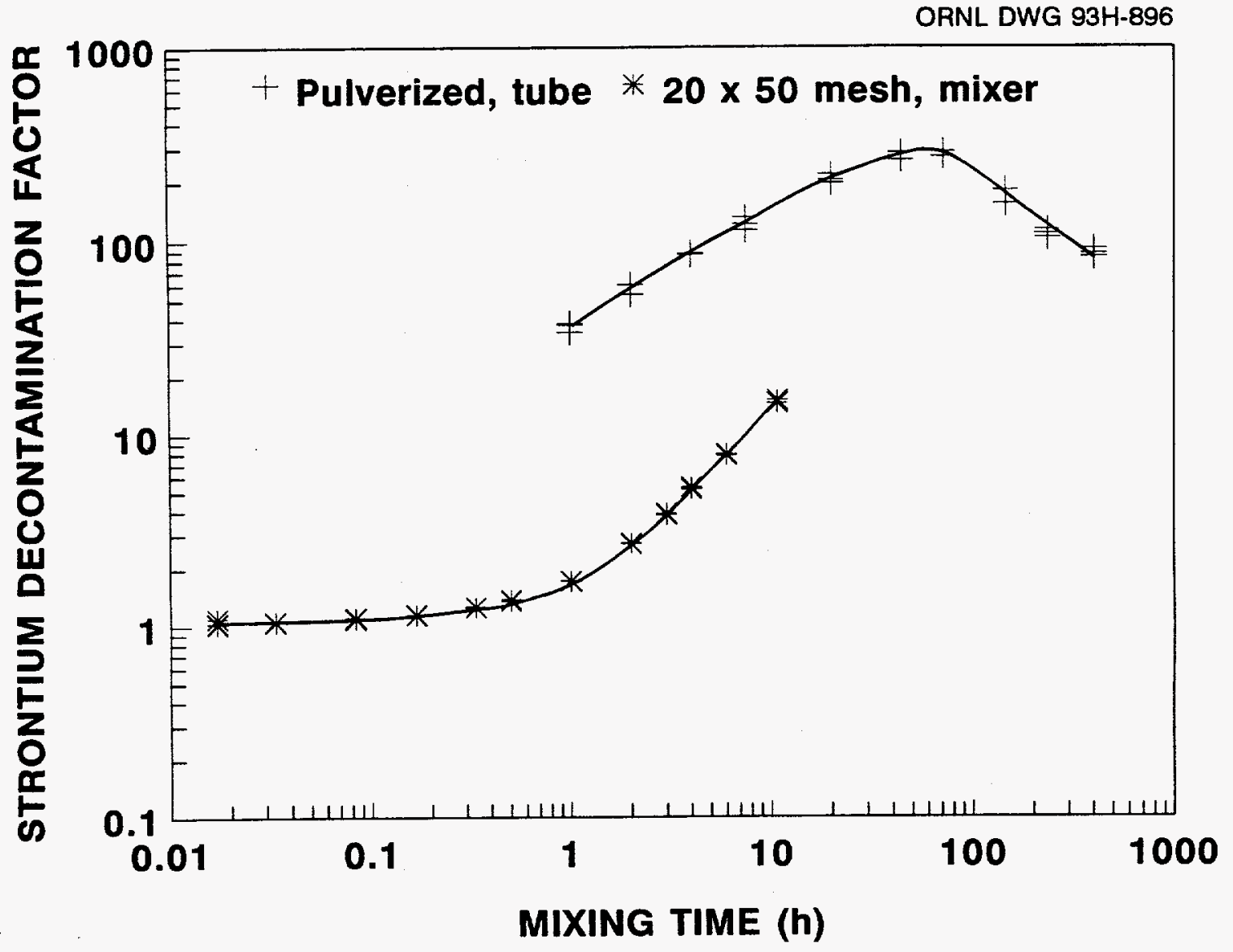

Fig. 6.16. Effect of mixing time on strontium sorption from simulated newly generated liquid low-level waste (NGLLLW) on sodium titanate. Procedure: Simulated NGLLLW $\left(0.141 \mathrm{mg} \mathrm{Sr} / \mathrm{L}\right.$, traced with ${ }^{85} \mathrm{Sr}$ ) was mixed with $500 \mathrm{ppm} 100$ to 325 mesh sodium titanate on a Labquake shaker or with $500 \mathrm{ppm} 20$ to 50 mesh sodium titanate in a small batch mixer (5-cm diam with 1.0 - by $0.5-\mathrm{cm}$ baffles at $90^{\circ}$, stirring at $300 \mathrm{rpm}$ with a $2.5-$ by $1.2-\mathrm{cm}$ impeller). For the tests with 100 to 325 mesh sodium titanate, sets of three samples were removed from the mixer as a function of time and centrifuged for $30 \mathrm{~min}$ at $5000 \mathrm{rcf}$. The ${ }^{85} \mathrm{Sr}$ count rates of the centrifuged solutions were measured. For the tests with 20 to 50 mesh sodium titanate, samples of the slurry were withdrawn from the mixer as a function of time and centrifuged for $30 \mathrm{~min}$ at $5000 \mathrm{rcf}$. The ${ }^{85} \mathrm{Sr}$ count rates of the centrifuged solutions were measured. 
been crushed and sized to 20 to 50 mesh or 100 to 325 mesh. The tests with 20 to 50 mesh granules were made in a small batch mixer at $300 \mathrm{rpm}$, and the tests with 100 to 325 mesh material were made with gentle shaking in centrifuge tubes at 20 cycles per minute on a Labquake shaker. Little sorption occurred on the granular sodium titanate for the first hour; then the decontamination factor increased from about 1.05 to about 15 after $10.8 \mathrm{~h}$. The decontamination factor was increasing at the end of the test. The decontamination factor with pulverized sodium titanate increased from 35 after $1 \mathrm{~h}$ to a maximum of about 280 after $72 \mathrm{~h}$ and then started decreasing. It was 110 after $240 \mathrm{~h}$ and 85 after $400 \mathrm{~h}$. These results indicate that more effective and more rapid strontium removal from simulated NGLLLW would be obtained in a batch operation with sodium titanate than in a column operation with granular sodium titanate.

Favorable results were obtained with four of the six sodium titanate samples tested in sorption isotherms from simulated NGLLLW at $\mathrm{pH} 13.1$, but results with the other samples were poor (Fig. 6.17). The maximum indicated strontium loading from simulated NGLLLW at $\mathrm{pH} 13.1$ was about $30 \mathrm{meq} / \mathrm{kg}$ with the Norton pellets (pulverized to 100 to 325 mesh); the older batch of powder from Cerac, Inc., the powder from Sandia; and the sodium titanate slurry. The sorption ratios at low strontium loading were on the order of $10^{6}$, and the decontamination factors with $500 \mathrm{ppm}$ of the sodium titanate were 200 to 400. Sorption with the recent batch of sodium titanate powder from Cerac and especially with the powder from Tam Ceramics was much weaker.

Small concentrations of calcium added to simulated NGLLLW severely depressed strontium sorption with sodium titanate (Fig. 6.18). The decontamination factor with $500 \mathrm{ppm}$ sodium titanate from pulverized pellets dropped from 160 with no calcium in the simulated NGLLLW to 39 with $5 \mathrm{ppm}$ calcium (added as $\mathrm{CaCl}_{2}$ ) and to 16 with $10 \mathrm{ppm}$ calcium. The decontamination factor stabilized at about 5 with calcium concentrations in the simulated NGLLLW of 20 to $80 \mathrm{ppm}$. Since process water at ORNL contains about $40 \mathrm{ppm}$ calcium, ${ }^{13}$ calcium interference with strontium sorption on sodium titanate would be likely. 
ORNL DWG 93H-897

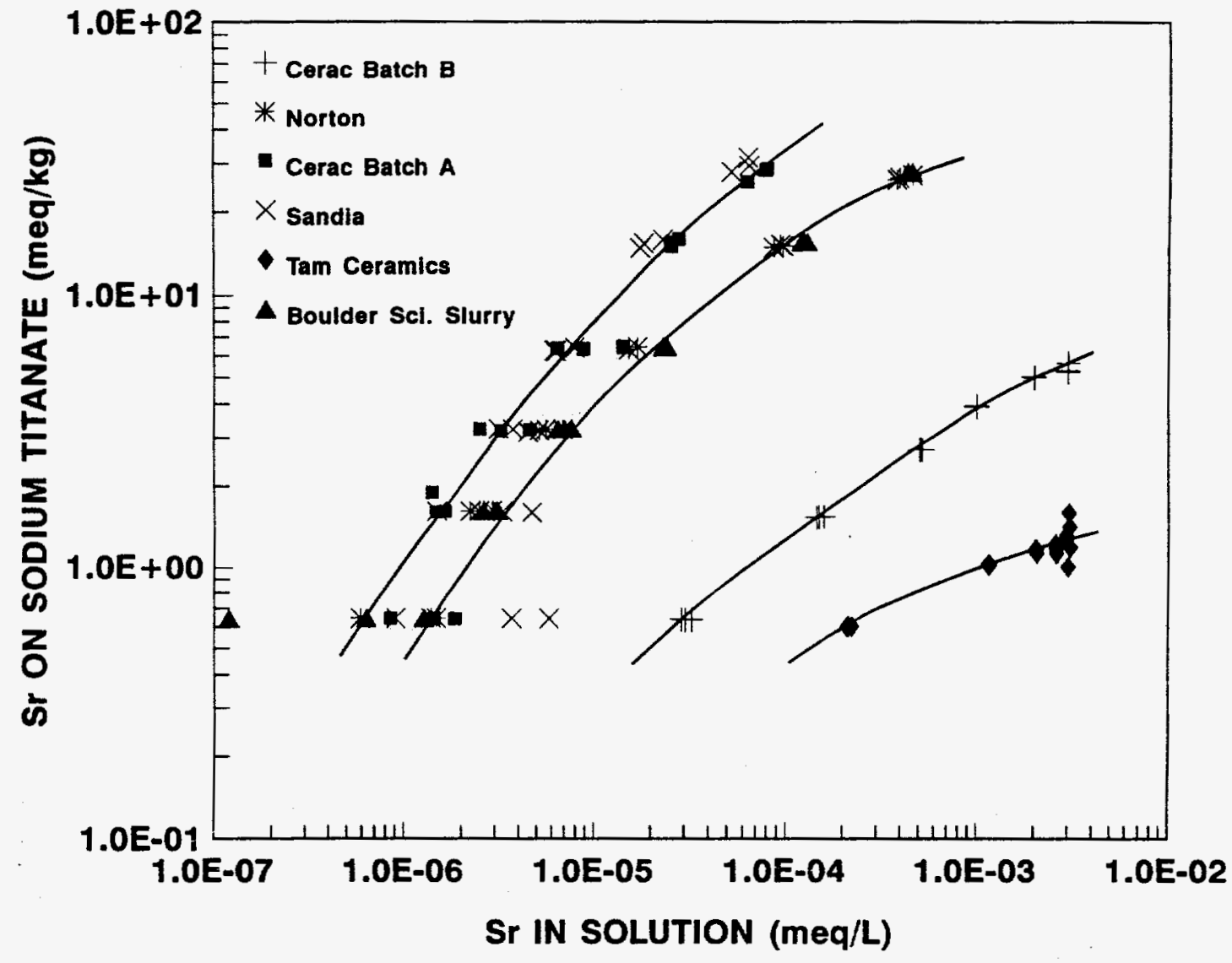

Fig. 6.17. Comparison of sodium titanate samples for strontium sorption from simulated newly generated liquid low-level waste (NGLLLW). Procedure: Sets of three samples of simulated NGLLLW $\left(0.141 \mathrm{mgSr} / \mathrm{L}\right.$, traced with $\left.{ }^{85} \mathrm{Sr}\right)$ were mixed for $20 \mathrm{~h}$ on a Labquake shaker with sodium titanate samples. The samples were centrifuged for $30 \mathrm{~min}$ at $5000 \mathrm{rcf}$, and the ${ }^{85} \mathrm{Sr}$ count rates of the centrifuged samples were measured. 
ORNL DWG $93 \mathrm{H}-898$

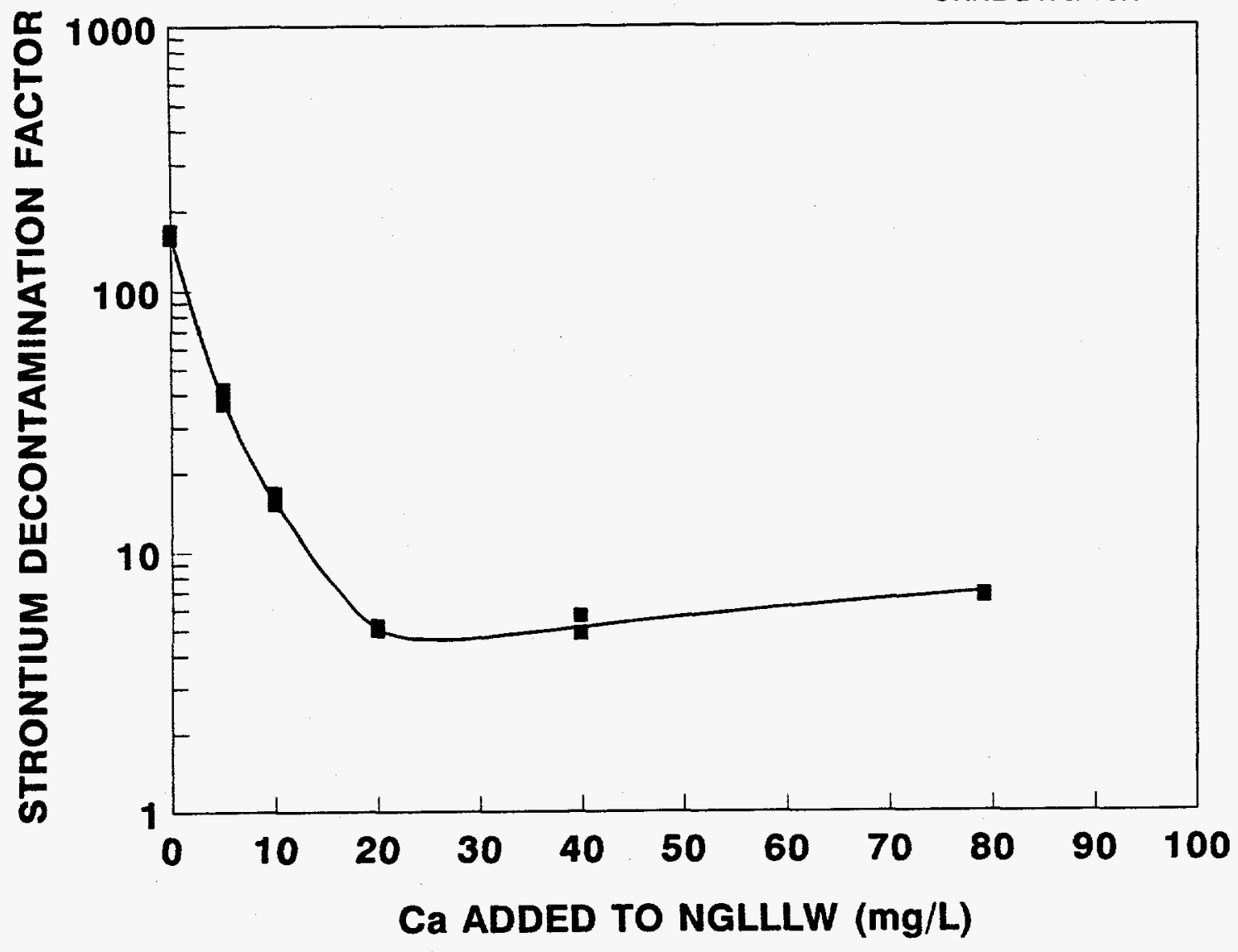

Fig. 6.18. Effect of calcium on strontium sorption from simulated newly generated liquid low-level waste (NGLLLW) with sodium titanate. Procedure: Sets of three samples of simulated NGLLLW $\left(0.141 \mathrm{mg} \mathrm{Sr} / \mathrm{L}\right.$, traced with $\left.{ }^{85} \mathrm{Sr}\right)$ containing 0 to $80 \mathrm{ppm}$ calcium, added as $\mathrm{CaCL}_{2}$ solution, were mixed for $20 \mathrm{~h}$ on a Labquake shaker with $500 \mathrm{ppm} 100$ to 325 mesh sodium titanate. The samples were centrifuged for $30 \mathrm{~min}$ at $5000 \mathrm{rcf}$, and the ${ }^{85} \mathrm{Sr}$ count rates of the centrifuged solutions were measured. 
The concentration of ${ }^{90} \mathrm{Sr}$ in MVST W-29 is $7000 \mathrm{~Bq} / \mathrm{mL},{ }^{3}$ which is equivalent to 0.19 $\mathrm{mCi} / \mathrm{L}$ (less than $1 \%$ of the concentration in NGLLLW), and no strontium decontamination would be required for discharge of the supernate to the PWTP. The higher salt content of simulated supernate did not significantly affect strontium sorption with sodium titanate when up to $50 \%$ simulated supernate was blended with simulated NGLLLW. The strontium decontamination factor with $500 \mathrm{ppm}$ of sodium titanate pellets (100 to 325 mesh) decreased slightly, but remained well above that needed for discharge to the PWTP (Fig. 6.19). The needed decontamination factor drops as the fraction of supernate is increased because of the low strontium concentration in the supernate.

\subsection{Strontium Removal with Other Exchangers}

Strontium sorption from simulated NGLLLW was measured with several other exchangers. None of them were as effective as the coprecipitation methods or sorption on sodium titanate.

Slight strontium sorption was measured on the resorcinol-formaldehyde SRS resin, which is primarily a cesium exchanger. Our strontium sorption results with this material are described along with the cesium results in Sect. 8. The resin had about the same strontium sorption power as the poorer batches of sodium titanate.

A Japanese paper ${ }^{14}$ reports strontium decontamination factors of $10^{4}$ on 0 -titanic acid, which is a form of hydrous titanium oxide, from $8 \mathrm{M} \mathrm{HNO}_{3}$ that had been adjusted to $\mathrm{pH}$ 8. A maximum decontamination factor of 10 was measured in our studies from simulated NGLLLW at pH 13 with 500 ppm hydrous titanium oxide. Strontium removal from the waste solution was lower at lower $\mathrm{pH}$ levels.

No significant strontium sorption from simulated NGLLLW occurred at $\mathrm{pH} 13$, with up to $2400 \mathrm{ppm}$ of small irregular granules of $\mathrm{Mg}(\mathrm{OH})_{2}$ held together with a binder. There was also no significant sorption at $\mathrm{pH}$ 7-13 from simulated NGLLLW with 500 ppm of two zeolites: TSM-140, a natural zeolite, and Ionsiv IE-96, a synthetic chabazite. 


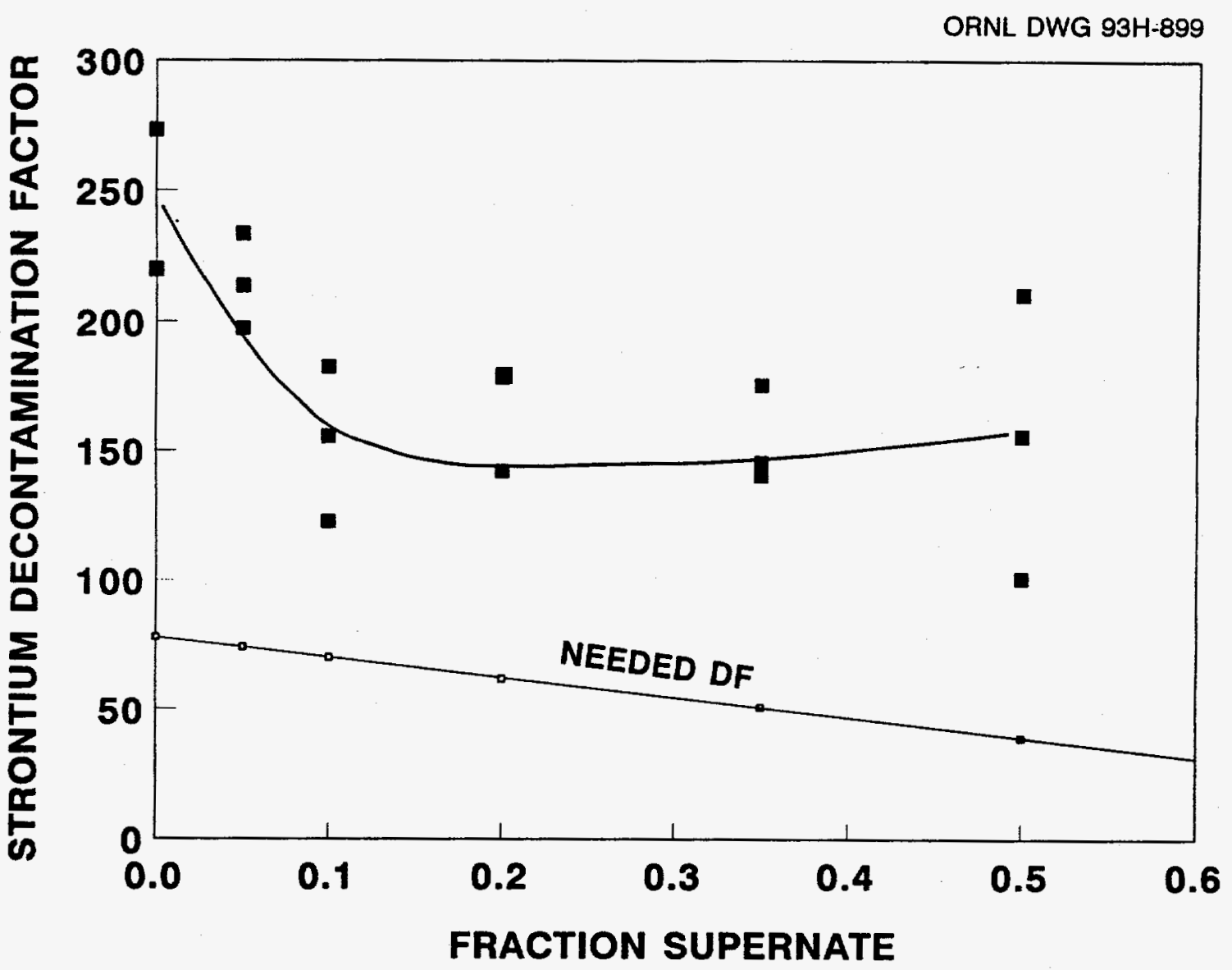

Fig. 6.19. Strontium sorption from mixtures of simulated newly generated liquid lowlevel waste (NGLLLW) and simulated Melton Valley Storage Tank (MVST) supernate with sodium titanate. Procedure: Sets of three samples of mixtures of simulated NGLLLW $(0.141 \mathrm{mg} \mathrm{Sr} / \mathrm{L})$ and simulated MVST supernate $(0.0013 \mathrm{mg} \mathrm{Sr} / \mathrm{L})$ were mixed for $20 \mathrm{~h}$ on a Labquake shaker with $500 \mathrm{ppm} 100$ to 325 mesh sodium titanate. The samples were centrifuged for $30 \mathrm{~min}$ at $5000 \mathrm{rcf}$, and the ${ }^{85} \mathrm{Sr}$ count rates of the centrifuged samples were measured. 
The solubility product for $\mathrm{SrHPO}_{4}$ in $1 \mathrm{~N} \mathrm{KOH}$ is $10^{-31}$, which should result in a much lower strontium solubility in NGLLLW than the approximately $4 \mathrm{ppm}$ that we measured for strontium carbonate. However, the strontium concentration was reduced by only a factor of 1.7 when $500 \mathrm{ppm} \mathrm{PO}_{4}{ }^{3-}$, as $\mathrm{KH}_{2} \mathrm{PO}_{4}$, was added to simulated NGLLLW at $\mathrm{pH}$ 13. In addition, strontium removal with $50 \mathrm{ppm}$ strontium or with $50 \mathrm{ppm}$ strontium $+25 \mathrm{ppm}$ iron was not improved by the addition of $500 \mathrm{ppm} \mathrm{PO}_{4}^{3-}$.

\section{CESIUM REMOVAL TEST RESULTS}

The most effective method tested for removing cesium from simulated NGLLLW was sorption on KCCF after adjustment to $\mathrm{pH} 8$. The preferred method of adding the KCCF to the simulated waste is as a slurry. The in situ slurry was formed by dissolving $\mathrm{K}_{4} \mathrm{Fe}(\mathrm{CN})_{6}$ in the waste solution and then adding a stoichiometric amount of $\mathrm{Co}\left(\mathrm{NO}_{3}\right)_{2}$ so that the KCCF was formed in the waste solution. The preformed slurry was prepared by mixing stoichiometric amounts of $\mathrm{K}_{4} \mathrm{Fe}(\mathrm{CN})_{6}$ and $\mathrm{Co}\left(\mathrm{NO}_{3}\right)_{2}$ to produce the KCCF slurry, which was then added to the NGLLLW. Two treatments or strikes are required to ensure that the needed cesium decontamination factor is achieved. A decontamination factor of about 3000 is obtained in the first strike with $100 \mathrm{ppm} \mathrm{KCCF}$. The second strike of the clarified solution with $50 \mathrm{ppm} \mathrm{KCCF}$ provides an additional decontamination factor of about 500 to 1000 . The KCCF slurries are far more efficient than granular KCCF or other exchangers tested. As described in Sect. 6, $\mathrm{Al}(\mathrm{OH})_{3}$ precipitates from the NGLLLW at about $\mathrm{pH} 10$. This precipitate, which is present in the first KCCF strike, removes significant amounts of strontium and ruthenium but none of the cesium from the solution. The precipitate aids in flocculation of the KCCF-cesium complex in the first strike.

\subsection{Cesium Removal with KCCF Slurry}

Cesium sorption with $500 \mathrm{ppm} \mathrm{KCCF}$ added as in situ or preformed slurry increased as the $\mathrm{pH}$ of the NGLLLW decreased (Fig. 7.1). Decontamination factors were less than 10 at $\mathrm{pH}$ values of 11 or above, but increased to about 3000 to 4000 at $\mathrm{pH} 8$. The preformed slurry was slightly more effective than the in situ slurry, especially in the range 


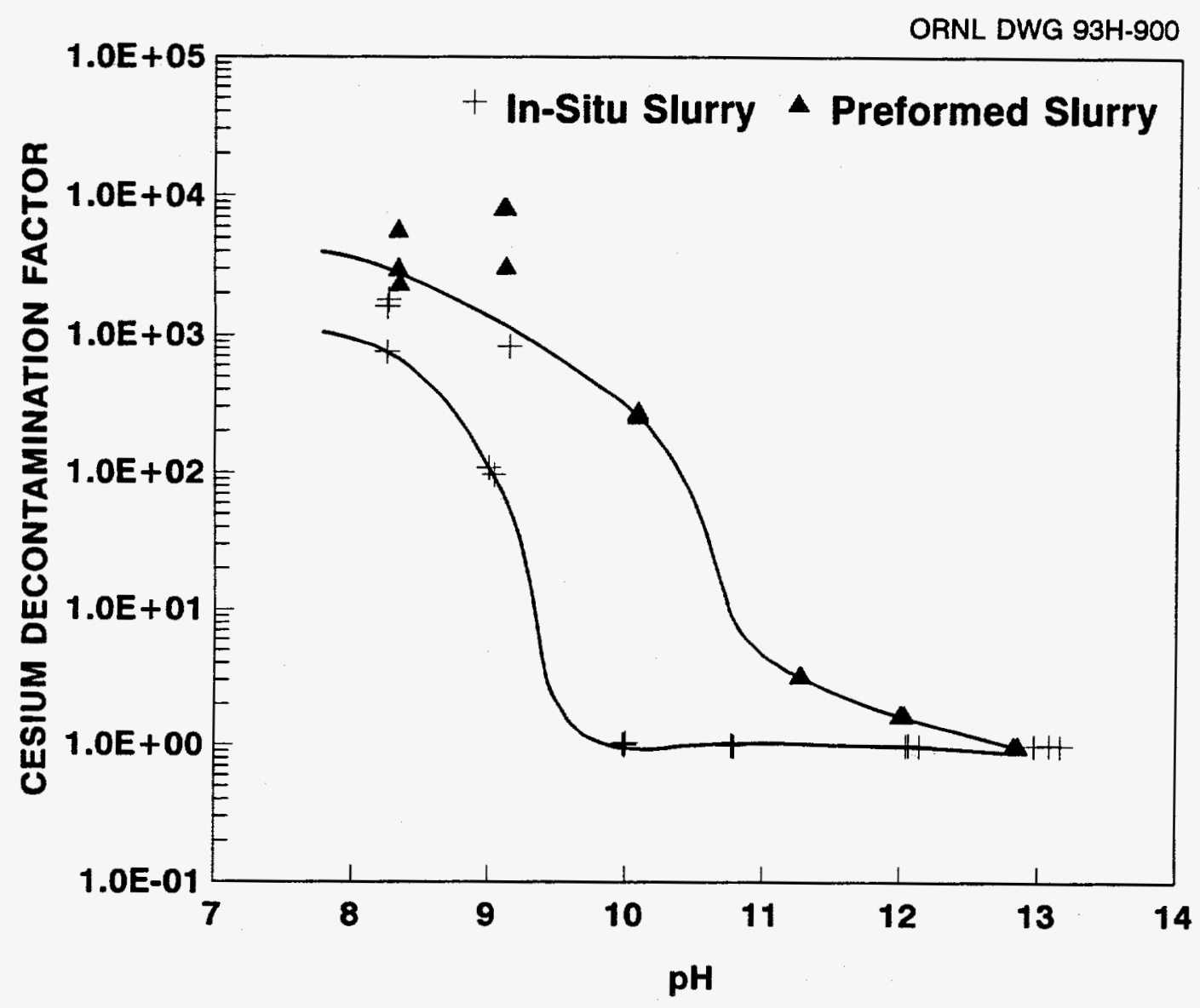

Fig. 7.1. Effect of pH on cesium sorption from simulated newly generated liquid lowlevel waste (NGLLLW) with in situ KCCF slurry. Procedure: The $\mathrm{pH}$ of simulated NGLLLW (1.16 mg Cs/L, traced with $\left.{ }^{137} \mathrm{Cs}\right)$ was adjusted with $5.4 \mathrm{~N} \mathrm{HCl}$. Triplicate samples of the adjusted solutions were mixed for $20 \mathrm{~h}$ on a Labquake shaker with $500 \mathrm{ppm}$ KCCF added as in situ or preformed slurry. The samples were centrifuged for $30 \mathrm{~min}$ at $5000 \mathrm{rcf}$, and the ${ }^{137} \mathrm{Cs}$ count rates of the centrifuged samples were measured. 
of $\mathrm{pH} 9$ to 11 . The preformed slurry is a very stable, uniform fluid. It is very thick and does not settle upon standing, but acts like a fluid and is easily handled.

A maximum cesium loading from simulated NGLLLW of about $700 \mathrm{meq} / \mathrm{kg}$ was measured in a sorption isotherm at pH 8 with in situ KCCF slurry (Fig. 7.2). This loading is about $12 \%$ of the calculated maximum KCCF loading if all of the potassium exchanges for cesium. Cesium sorption ratios were $>10^{7}$ at low cesium loadings, and the cesium decontamination factor obtained with $100 \mathrm{ppm} \mathrm{KCCF}$ was about 4000 . The isotherm was performed by contacting simulated NGLLLW that had been adjusted to pH 8 with 10 to $2000 \mathrm{ppm}$ in situ KCCF for $20 \mathrm{~h}$.

Cesium sorption from simulated NGLLLW at $\mathrm{pH} 8$ was strongly depressed by the presence of potassium in the simulated waste solution, but sodium concentration and total salt concentration had little effect (Fig. 7.3). For measurement of the effect of potassium, a series of simulated NGLLLW solutions was prepared in which part of the sodium carbonate was replaced by potassium carbonate. The initial $\mathrm{K}_{2} \mathrm{CO}_{3}$ concentration ranged from 0.0 to $0.587 \mathrm{~mol} / \mathrm{L}$, the concentration of $\mathrm{Na}_{2} \mathrm{CO}_{3}$ normally found in the NGLLLW. The solutions were adjusted to $\mathrm{pH} 8$ and treated with $100 \mathrm{ppm}$ in-situ KCCF slurry. The cesium decontamination factor was about 3000 in the tests with no potassium present, but dropped to about 200 with $0.2 \mathrm{~mol} / \mathrm{L}$ potassium, to 65 with $0.5 \mathrm{~mol} / \mathrm{L}$ potassium, and to 30 with $1.17 \mathrm{~mol} / \mathrm{L}$ potassium. Sodium concentration had a much smaller effect on cesium sorption from NGLLLW. Sodium nitrate was added to simulated NGLLLW to increase the initial sodium concentration (and also the total salt concentration). The usual concentration of sodium in the simulated NGLLLW is slightly less than $1.6 \mathrm{~mol} / \mathrm{L}$, mostly from $\mathrm{Na}_{2} \mathrm{CO}_{3}$. The solutions were adjusted to $\mathrm{pH} 8$, and cesium sorption with $100 \mathrm{ppm}$ in situ KCCF slurry was measured. The cesium decontamination factor decreased from about 3000 with $1.6 \mathrm{~mol} / \mathrm{L}$ initial sodium (no added $\mathrm{NaNO}_{3}$ ) to about 800 with $4.5 \mathrm{~mol} / \mathrm{L}$ initial sodium.

The KCCF-cesium complex formed from NGLLLW at $\mathrm{pH} 8$ with in situ KCCF slurry was stable for up to 23 days (Fig. 7.4). In these tests, $20 \mathrm{ppm}$ of the KCCF slurry was added to NGLLLW that had been adjusted to $\mathrm{pH} 8$, and cesium decontamination factors were measured as a function of mixing time. The decontamination factor reached 2100 


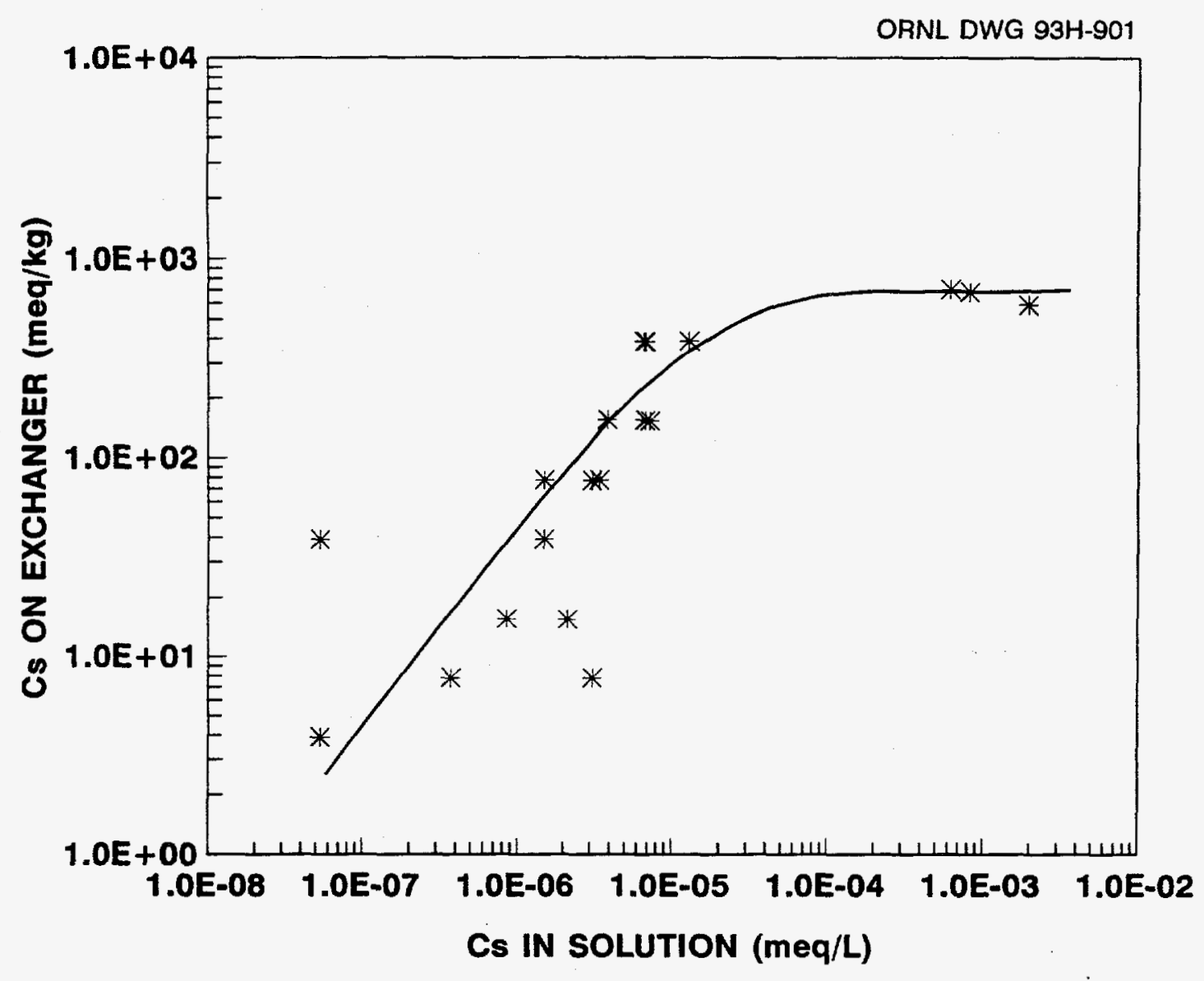

Fig.7.2. Isotherm for cesium sorption from simulated newly generated liquid low-level waste (NGLLLW) with KCCF slurry. Procedure: Simulated NGLLLW (1.16 mg Cs/L, traced with ${ }^{137} \mathrm{Cs}$ ) was adjusted to $\mathrm{pH} 8$ with $5.4 \mathrm{~N} \mathrm{HCl}$, and sets of three samples were mixed for $20 \mathrm{~h}$ on a Labquake shaker with in situ KCCF slurry. The samples were centrifuged for $30 \mathrm{~min}$ at $5000 \mathrm{rcf}$, and the ${ }^{137} \mathrm{Cs}$ count rates of the centrifuged samples were measured. 


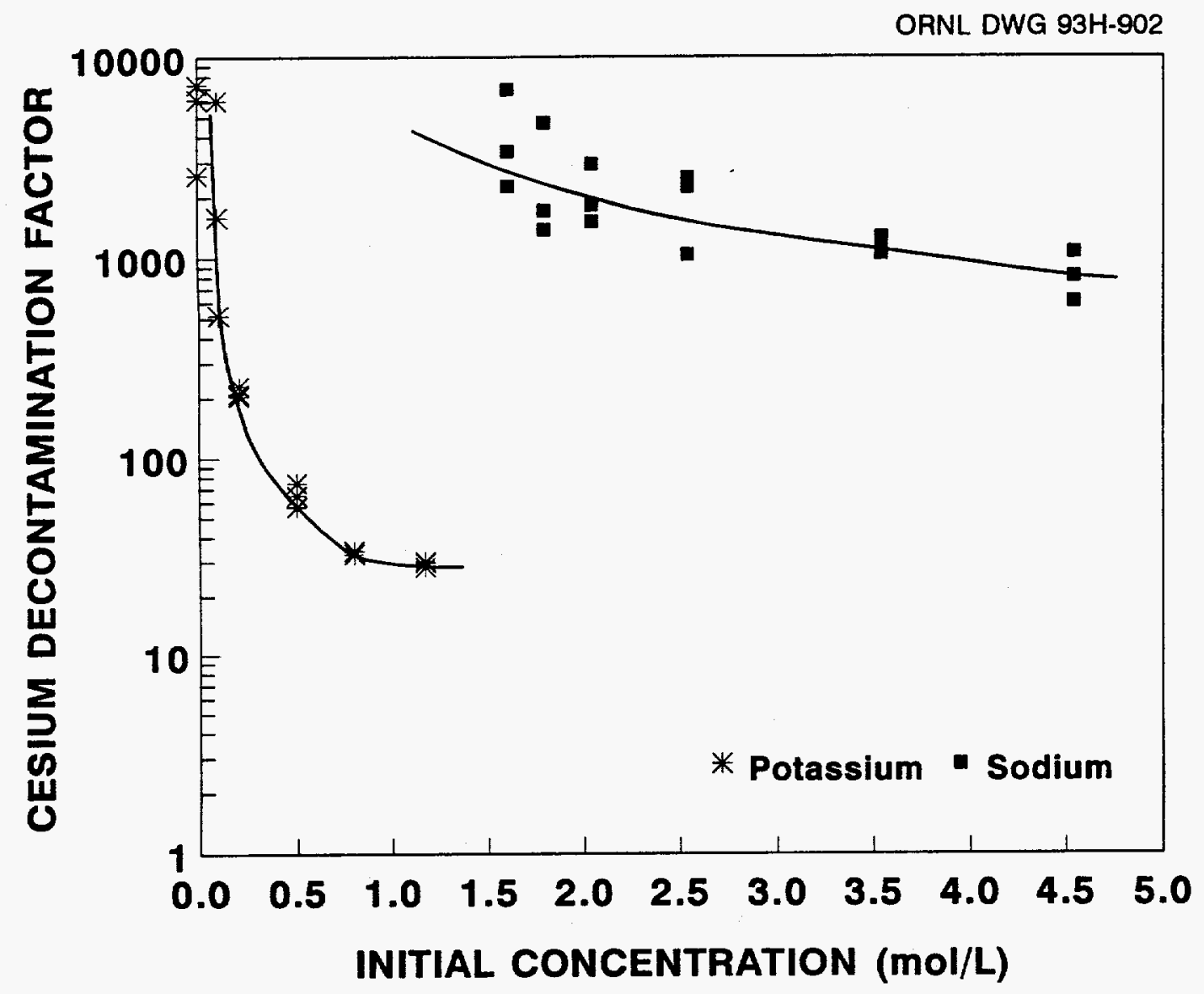

Fig. 73. Effects of potassium and sodium concentrations on cesium sorption from simulated newly generated liquid low-level waste (NGLLLW) with in situ KCCF slurry. Procedure: The composition of simulated NGLLLW was modified by replacing part or all of the $\mathrm{Na}_{2} \mathrm{CO}_{3}$ with $\mathrm{K}_{2} \mathrm{CO}_{3}$ or by adding $\mathrm{NaNO}_{3}$ to the solution. The solutions $(1.16 \mathrm{mg} \mathrm{Cs} / \mathrm{L}$, traced with ${ }^{137} \mathrm{Cs}$ ) were adjusted to $\mathrm{pH} 8$ with $5.4 \mathrm{~N} \mathrm{HCl}$, and sets of three samples were mixed for $20 \mathrm{~h}$ on a Labquake shaker with $100 \mathrm{ppm}$ in situ KCCF slurry. The samples were centrifuged for $30 \mathrm{~min}$ at $5000 \mathrm{rcf}$, and the ${ }^{137} \mathrm{Cs}$ count rates of the centrifuged solutions were measured. 


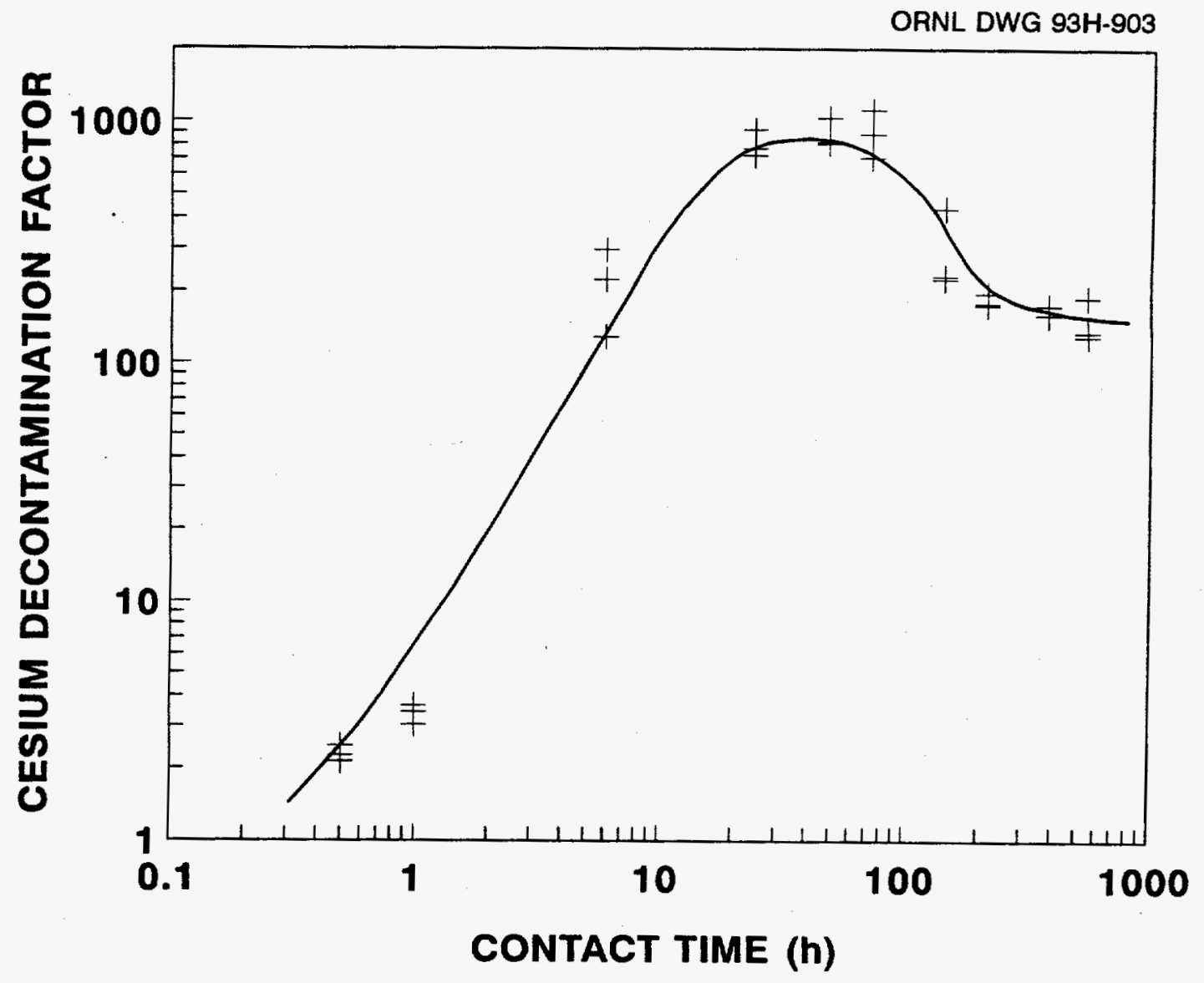

Fig. 7.4. Effect of contact time on cesium sorption from simulated newly generated liquid low-level waste (NGLLLW) on in situ KCCF slurry. Procedure: Simulated NGLLLW (1.16 mg Cs/L, traced with ${ }^{137} \mathrm{Cs}$ ) was adjusted to $\mathrm{pH} 8$ with $5.4 \mathrm{~N} \mathrm{HCl}$ and mixed for $20 \mathrm{~h}$ on a Labquake shaker with $20 \mathrm{ppm}$ in situ KCCF slurry. Sets of three samples were removed from the shaker as a function of time and centrifuged for $30 \mathrm{~min}$ at $5000 \mathrm{rcf}$. The ${ }^{137} \mathrm{Cs}$ count rates of the centrifuged samples were measured. The contact time does not include the centrifugation time. 
after $6 \mathrm{~b}$ of mixing on the Labquake shaker and continued to increase to a maximum value of about 800 after 24 to $72 \mathrm{~h}$. The decontamination factor then decreased to between 100 and 200; it was essentially constant at about 150 for the last 17 days of the test. These results are in contrast to previous results, in which cesium sorption with granular KCCF from simulated supernate at $\mathrm{pH} 13$ reached a maximum after 1 day of contact and decreased steadily thereafter. ${ }^{15}$

Preformed KCCF slurry maintained its cesium sorption power for about 14 days, and then its effectiveness decreased (Fig. 7.5). The stoichiometric KCCF slurry was added at $100 \mathrm{ppm}$ to NGLLLW at pH 8 and mixed for $20 \mathrm{~h}$. The cesium decontamination factor dropped from about 2400 immediately after the slurry preparation to about 1800 after the slurry had aged for 1 to 14 days. The decontamination factor then decreased to about 1300 after the slurry had aged for 20 days and to 950 after it had aged for 27 days.

The results of tests made in a small batch mixer showed that the cesium sorption rate from NGLLLW waste at $\mathrm{pH} 8$ with in situ KCCF slurry increased as the KCCF concentration was increased from $10 \mathrm{ppm}$ to $100 \mathrm{ppm}$ (Fig. 7.6). A maximum cesium decontamination factor of about 4000 was reached in 1 min with $100 \mathrm{ppm} \mathrm{KCCF}$ and in 30 min with $50 \mathrm{ppm} \mathrm{KCCF}$. The decontamination factor with $20 \mathrm{ppm}$ KCCF was only 4.3 after $6 \mathrm{~h}$, and no measurable cesium sorption occurred with $10 \mathrm{ppm} \mathrm{KCCF} \mathrm{in} \mathrm{this} \mathrm{time.}$

Cesium sorption from simulated NGLLLW was effective in a test designed to simulate a second strike with KCCF slurry, after the bulk of the cesium had been removed with a first KCCF strike (Fig 7.7). In these tests, simulated NGLLLW was adjusted to $\mathrm{pH} 8$ and centrifuged. The clear solution was decanted, and part of it was adjusted to $\mathrm{pH}$ 9. The cesium concentration at $\mathrm{pH} 8$ was $0.0022 \mathrm{ppm}$, which corresponds to the concentration that would remain after a decontamination factor of 500 in the first strike. The adjusted solutions were contacted with 20 to $100 \mathrm{ppm}$ of preformed KCCF slurry that had been prepared immediately before the sorption tests. The decontamination factor after a 20-h contact on a Labquake shaker was about 2500 with $100 \mathrm{ppm} \mathrm{KCCF}$ and about 2000 with $50 \mathrm{ppm} \mathrm{KCCF}$ at $\mathrm{pH} 8$ or $\mathrm{pH} 9$. With $20 \mathrm{ppm} \mathrm{KCCF}$, the decontamination factor was 700 at $\mathrm{pH} 8.3$ and 40 at $\mathrm{pH} 9.1$. The bulk of the aluminum precipitates from 


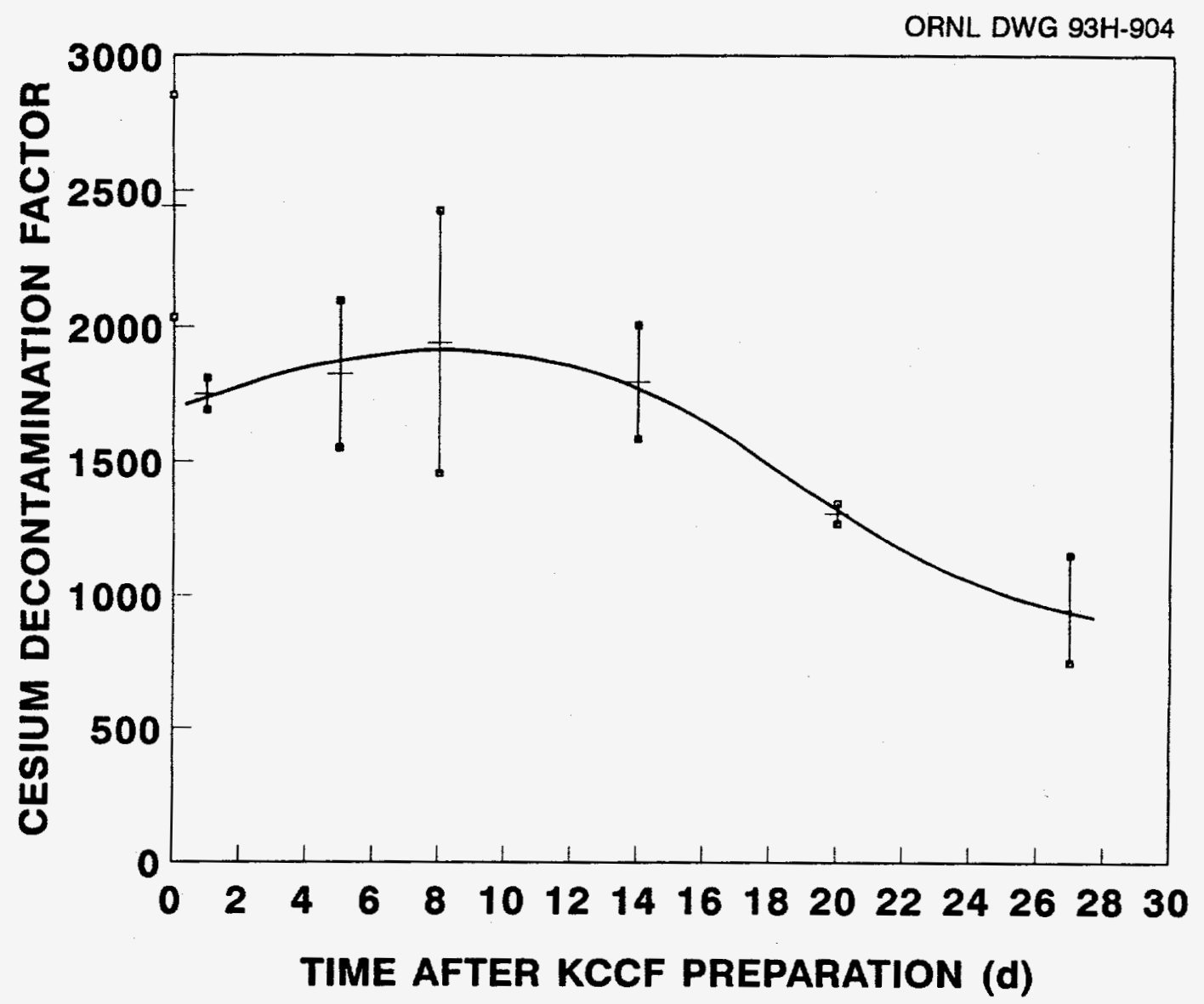

Fig. 7.5. Effect of preformed KCCF slurry age on cesium sorption from simulated newly generated liquid low-level waste (NGLLLW). Procedure: Simulated NGLLLW $\left(1.16 \mathrm{mg} \mathrm{Cs} / \mathrm{L}\right.$, traced with ${ }^{137} \mathrm{Cs}$ ) was adjusted to $\mathrm{pH} 8$ with $5.4 \mathrm{~N} \mathrm{HCl}$, and sets of three samples were mixed for $20 \mathrm{~h}$ on a Labquake shaker with $100 \mathrm{ppm}$ preformed KCCF slurry as a function of time after preparation of the slurry. The samples were centrifuged for $30 \mathrm{~min}$ at $5000 \mathrm{rcf}$, and the ${ }^{137} \mathrm{Cs}$ count rates of the centrifuged solutions were measured. 


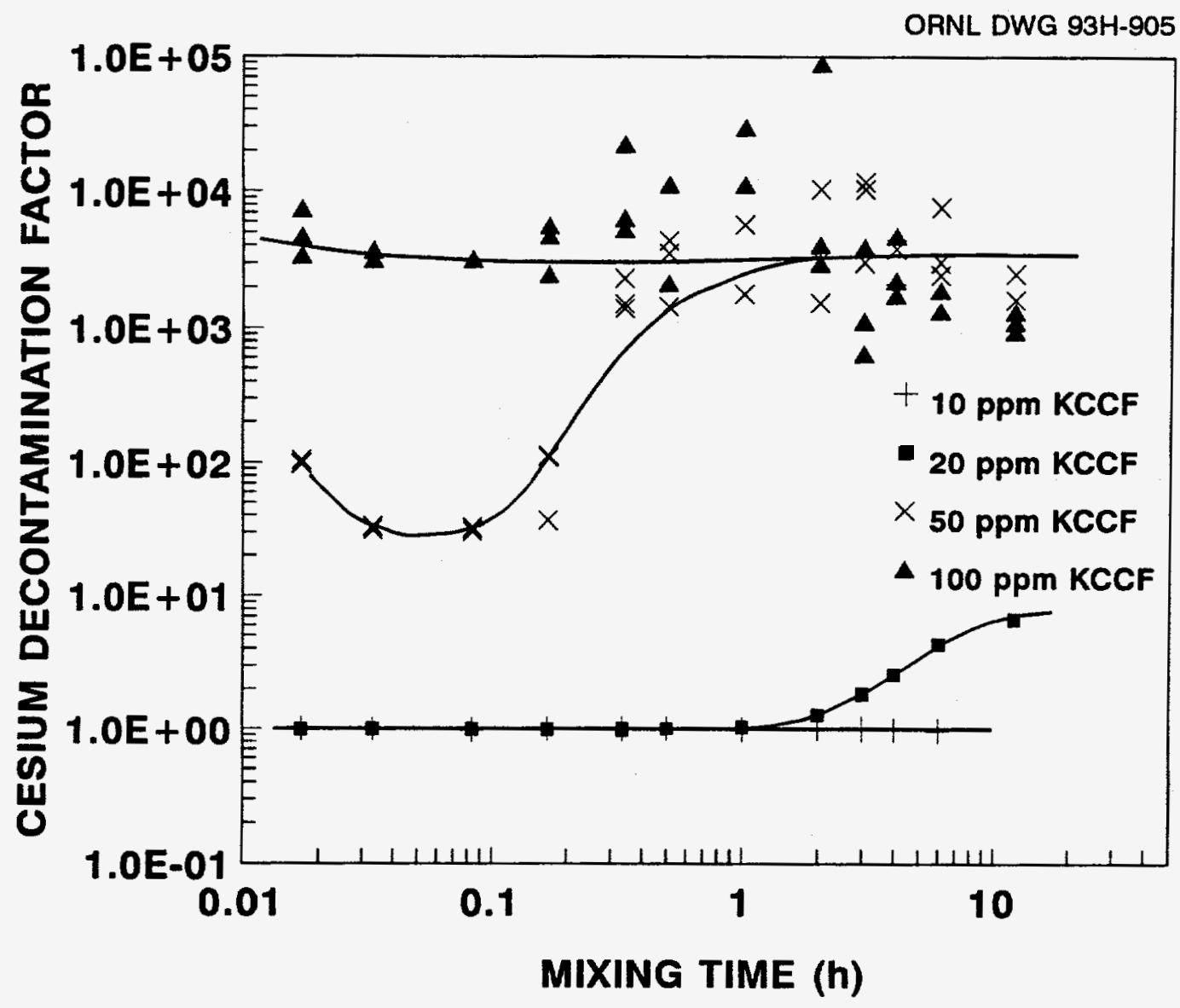

Fig. 7.6. Effect of mixing time on cesium sorption from simulated newly generated liquid low-level waste (NGLLLW) with in situ KCCF slurry. Procedure: Simulated NGLLLW (1.16 mg Cs/L, traced with ${ }^{137} \mathrm{Cs}$ ) was adjusted to $\mathrm{pH} 8$ with $5.4 \mathrm{~N} \mathrm{HCl}$ and mixed in a small batch mixer $\left(5-\mathrm{cm}\right.$ diam with $1.0-$ by $0.5-\mathrm{cm}$ baffles at $90^{\circ}$, stirring at $300 \mathrm{rpm}$ with a 2.5 - by $1.2-\mathrm{cm}$ impeller) with in situ KCCF slurry. Samples were removed from the mixer as a function of time and centrifuged for $1 \mathrm{~min}$ at $700 \mathrm{rcf}$. The solutions were decanted and centrifuged a second time for $30 \mathrm{~min}$ at $5000 \mathrm{rcf}$. The ${ }^{137} \mathrm{Cs}$ count rates of three aliquots of each twice-centrifuged solutions were measured. The mixing time indicated on the plot does not include the centrifugation time. 


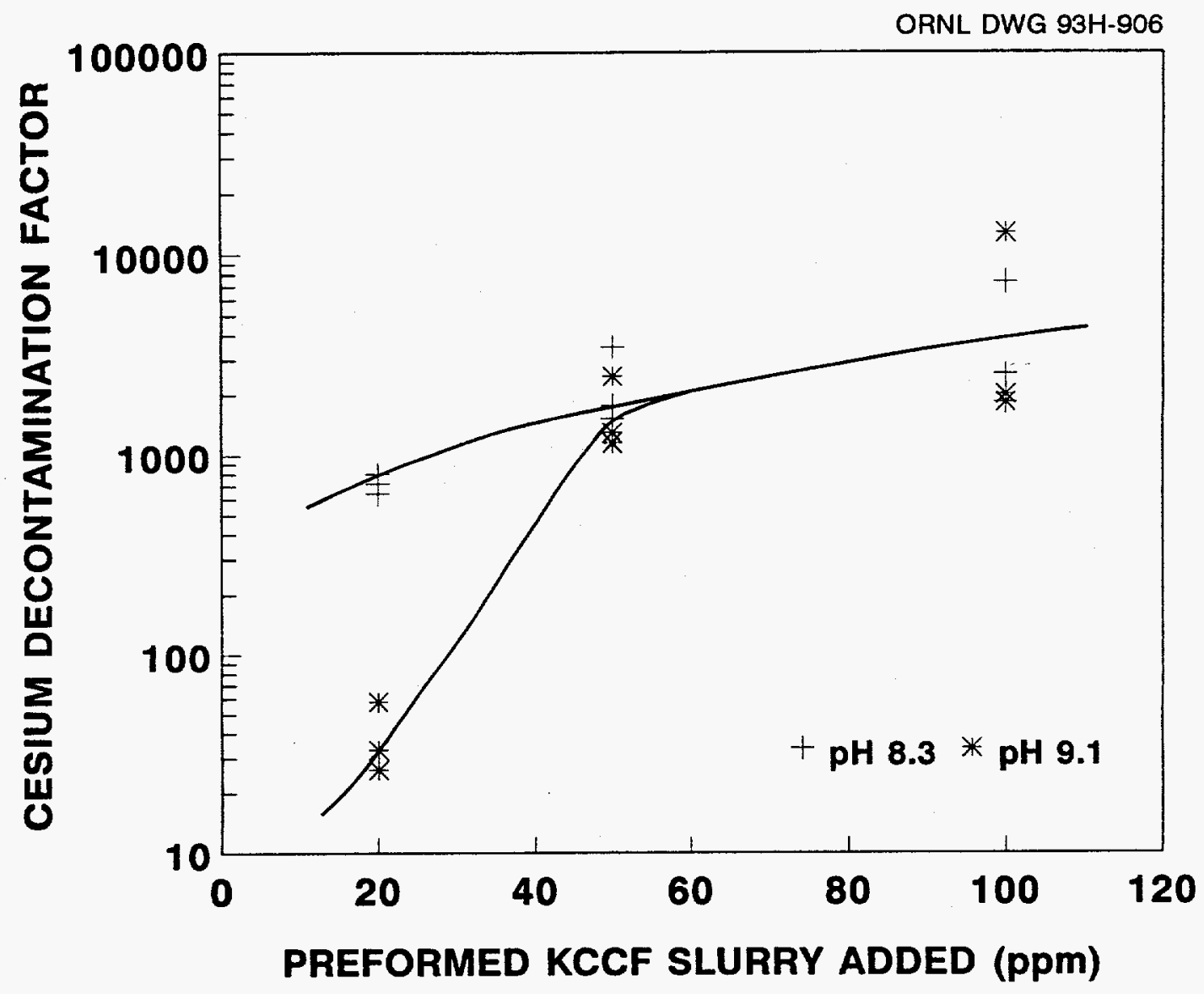

Fig. 7.7. Cesium sorption from simulated newly generated liquid low-level waste (NGLLLW) in a second strike with in situ KCCF slurry. Procedure: Simulated NGLLLW was adjusted to $\mathrm{pH} 8$ with $5.4 \mathrm{~N} \mathrm{HCl}$, centrifuged for $30 \mathrm{~min}$ at $5000 \mathrm{rcf}$, and decanted. Stable cesium $(0.0022 \mathrm{mg} / \mathrm{L})$ and ${ }^{137} \mathrm{Cs}$ tracer were added to the decanted solution, part of the solution was adjusted to $\mathrm{pH} 9$ with $\mathrm{NaOH}$, and sets of three samples were mixed for $20 \mathrm{~h}$ on a Labquake shaker with preformed KCCF slurry. The samples were centrifuged for 30 min at $5000 \mathrm{rcf}$, and the ${ }^{137} \mathrm{Cs}$ count rates of the centrifuged solutions were measured. 
the NGLLLW at about $\mathrm{pH} 10$. An additional amount of $\mathrm{Al}(\mathrm{OH})_{3}$ (about $1 \%$ or less) precipitates from NGLLLW that has been adjusted to $\mathrm{pH} 8$ and clarified. This postprecipitation occurs after $\mathrm{pH}$ adjustment during overnight standing. If in actual operation, processing delays are encountered after the first KCCF treatment step, these precipitates would be encountered. The precipitates could cause problems if subsequent treatment involves down-flow column operations which do not tolerate suspended solids. The precipitate was first observed with a NGLLLW solution that had stood for 5 days after $\mathrm{pH}$ adjustment, centrifugation, and decantation. Subsequent aluminum solubility tests confirmed aluminum postprecipitation, more at $\mathrm{pH} 8$ than at $\mathrm{pH} 9$. After adjustment to $\mathrm{pH} 8$ and centrifugation, the simulated NGLLLW solution contained $2.76 \mathrm{mg} / \mathrm{L}$ of aluminum. The aluminum concentration decreased to $0.66 \mathrm{mg} / \mathrm{L}$ after 3 days and was stable at that value for 18 days. The $\mathrm{pH}$ of the solution increased from 8.08 to 9.37 in the 18-day period. For the measurements at $\mathrm{pH} \mathrm{9,} \mathrm{the} \mathrm{simulated} \mathrm{NGLLLW} \mathrm{solution} \mathrm{was}$ adjusted to $\mathrm{pH} \mathrm{8,} \mathrm{centrifuged} \mathrm{and} \mathrm{decanted,} \mathrm{and} \mathrm{then} \mathrm{adjusted} \mathrm{to} \mathrm{pH} 9$. The aluminum concentration in this solution decreased from $2.16 \mathrm{mg} / \mathrm{L}$ of aluminum immediately after adjustment to $\mathrm{pH} 9$ to $1.63 \mathrm{mg} / \mathrm{L}$ after 17 days. The $\mathrm{pH}$ increased from 9.05 to 9.62 in the 17 days. The aluminum postprecipitation did not affect the concentration of cesium or strontium in the solution; the concentration of neither changed significantly in 14 days. The $\mathrm{pH}$ increase after adjustment also did not affect cesium sorption by KCCF. The cesium decontamination factor with $100 \mathrm{ppm}$ in situ KCCF slurry from simulated NGLLLW initially adjusted to $\mathrm{pH} 8$ was 3000 to 4000 for 14 days after $\mathrm{pH}$ adjustment (Fig 7.8). The $\mathrm{pH}$ of the solution did not change during contact with KCCF slurry. The simulated NGLLLW solution was centrifuged immediately after $\mathrm{pH}$ adjustment, but the $\mathrm{Al}(\mathrm{OH})_{3}$ that formed after centrifugation remained in the solution during the sorption measurements.

\section{Cesium Removal from Simulated NGLLLW with Granular KCCF}

Granular KCCF was less effective than KCCF slurry for cesium sorption from NGLLLW (Fig. 7.9). The granular KCCF used in these tests was from a supply used in studies reported by Campbell et al. in 1991 (ref. 2), and will be referred to as the "reference" KCCF. Sorption from simulated NGLLLW with granular KCCF was more 


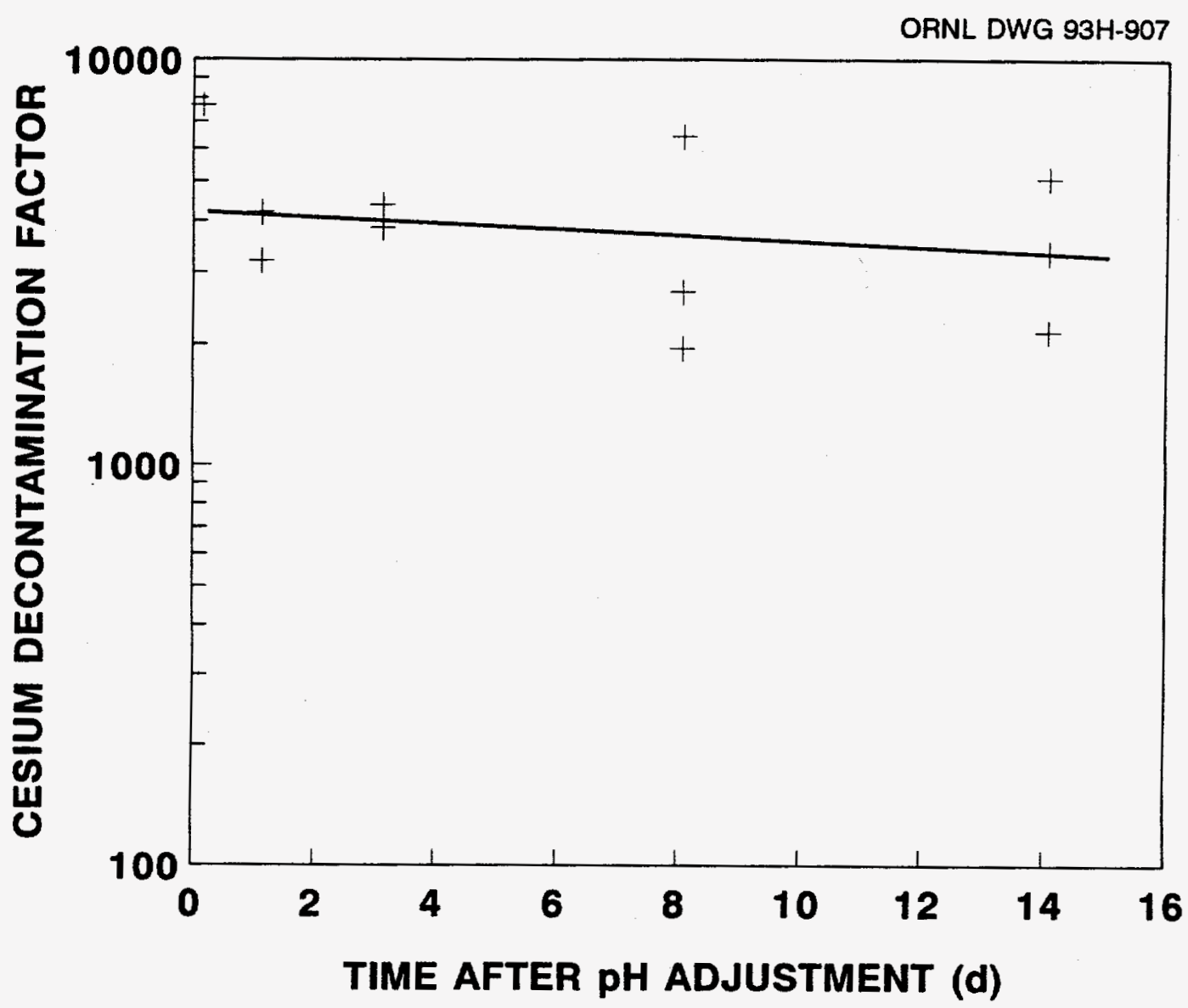

Fig. 7.8. Effect of time after $\mathrm{pH}$ adjustment on cesium sorption from simulated newly generated liquid low-level waste (NGLLLW) with in situ KCCF slurry. Procedure: Simulated NGLLLW (1.16 mg Cs/L, traced with ${ }^{137} \mathrm{Cs}$ ) was adjusted to $\mathrm{pH} 8$ with $5.4 \mathrm{~N} \mathrm{HCl}$, and sets of three samples were taken as a function of time and mixed for $20 \mathrm{~h}$ on a Labquake shaker with $100 \mathrm{ppm}$ in situ KCCF slurry. The samples were centrifuged for $30 \mathrm{~min}$ at $5000 \mathrm{rcf}$, and the ${ }^{137} \mathrm{Cs}$ count rates of the centrifuged solutions were measured. 
ORNL DWG 93H-908

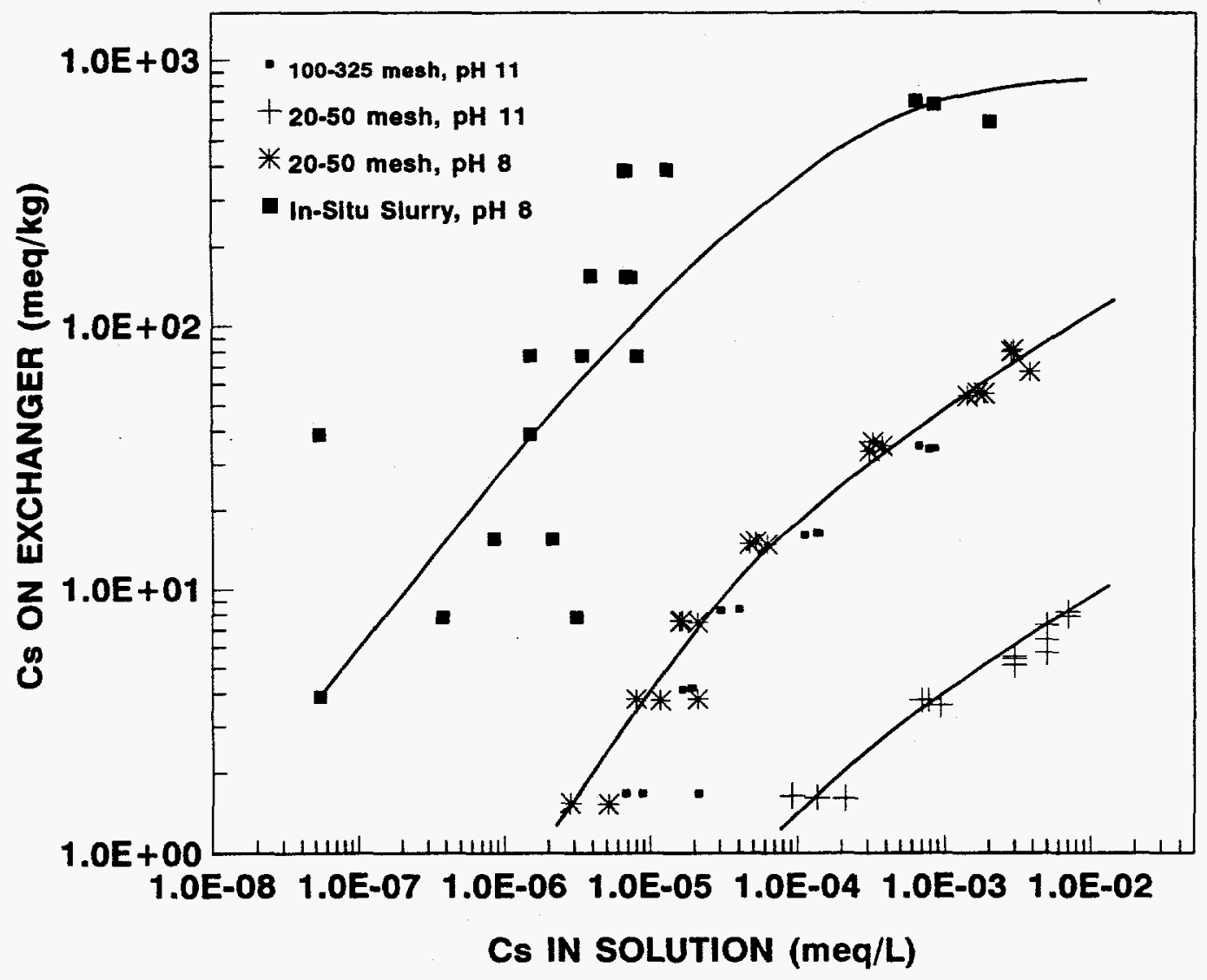

Fig. 7.9. Isotherms for cesium sorption from simulated newly generated liquid lowlevel waste (NGLLLW) with granular KCCF. Procedure: Simulated NGLLLW (1.16 mg $\mathrm{Cs} / \mathrm{L}$, traced with ${ }^{137} \mathrm{Cs}$ ) was adjusted to $\mathrm{pH} 8$ with $5.4 \mathrm{~N} \mathrm{HCl}$, and sets of three samples were mixed for $20 \mathrm{~h}$ on a Labquake shaker with in situ KCCF slurry or with granular KCCF. The samples were centrifuged for $30 \mathrm{~min}$ at $5000 \mathrm{rcf}$, and the ${ }^{137} \mathrm{Cs}$ count rates of the centrifuged solutions were measured. 
effective at pH 8 than at $\mathrm{pH} 11$, and 100 to 325 mesh KCCF was more effective than 20 to 50 mesh KCCF. These isotherms were made by contacting NGLLLW with from 10 to $5000 \mathrm{~g}$ of $\mathrm{KCCF}$ for $20 \mathrm{~h}$. The 20 to 50 mesh KCCF was slightly more effective at pH 8 than the pulverized $\mathrm{KCCF}$ at $\mathrm{pH} 11$, indicating that $\mathrm{pH}$ is more important than particle size for cesium sorption. The maximum cesium loading of the KCCF reached was about $80 \mathrm{meq} / \mathrm{kg}$, about $1.4 \%$ of the calculated saturation loading if all of the potassium exchanges for cesium. The cesium decontamination factors at the highest KCCF dose rates $(5000 \mathrm{ppm})$ were greater than 1000 in the isotherm at $\mathrm{pH} 8$ and were near 1000 in the isotherm with 100 to 325 mesh KCCF at pH 11. Sorption with 20 to 50 mesh KCCF was less effective at $\mathrm{pH} 11$ than at $\mathrm{pH} 8$.

Four 10-g batches of granular KCCF were prepared by an adaptation of the method described in ref. 2. A $0.5-\mathrm{mol} / \mathrm{L} \mathrm{K}_{4} \mathrm{Fe}(\mathrm{CN})_{6}$ solution was added to $0.3-\mathrm{mol} / \mathrm{L}$ $\mathrm{Co}\left(\mathrm{NO}_{3}\right)_{2}$ solution over a 20 -min period. The solutions were maintained at $15^{\circ} \mathrm{C}$ during the addition and the 20-min digestion period that followed, after which the reaction mixture was centrifuged for $10 \mathrm{~min}$ at $5000 \mathrm{rcf}$ and the solution was decanted. The solids were washed four times with $1-\mathrm{mol} / \mathrm{KNO}_{3}$ solution and then once with water, using $20 \mathrm{~mL}$ of solution per gram of solids in each wash. The samples were centrifuged for 20 min at 5000 rcf after each wash, and the wash solutions were decanted. The washed solids were air dried and then dried overnight at $115^{\circ} \mathrm{C}$. Three of the batches were prepared using $40 \%$ excess cobalt in the reaction mixture, and the fourth batch was prepared using stoichiometric amounts of the reactants. The nearly black, shiny solids were crushed and sized to 20 to 50 mesh before use in tests to compare the cesium sorption properties of the four batches with those of the reference KCCF. The simulated NGLLLW was adjusted to $\mathrm{pH} 11$ or pH 8 and contacted for $20 \mathrm{~h}$ with $500 \mathrm{ppm}$ of 20 to 50 mesh exchanger. The results of the sorption tests show considerable variation in the cesium decontamination factors measured for the different KCCF batches at $\mathrm{pH} 11$ (Table 7.1). Two of the batches had decontamination factors of about 75 , and the other two had decontamination factors of 2 to 4. Cesium sorption with the four KCCF batches was higher and also more consistent at $\mathrm{pH} 8$ than at $\mathrm{pH}$ 11. Decontamination factors were approximately 1000 for all four batches. All four batches were more effective than the reference $\mathrm{KCCF}$ at both $\mathrm{pH}$ levels. Cesium sorption with the stoichiometric KCCF 
Table 7.1. Comparison of KCCF batches

\begin{tabular}{ccc}
\hline & \multicolumn{2}{c}{ Cesium decontamination factor } \\
\cline { 2 - 3 } KCCF batch & $\mathrm{pH} 11$ & $\mathrm{pH} 8$ \\
\hline A & $3.9 \pm 1.6$ & $1507 \pm 299$ \\
B & $2.6 \pm 0.1$ & $842 \pm 192$ \\
C & $78.5 \pm 25.8$ & $1349 \pm 55$ \\
D & $74.7 \pm 5.8$ & $1045 \pm 116$ \\
Ref & $1.7 \pm 0.1$ & $151 \pm 6$ \\
\hline
\end{tabular}

"Procedure: Triplicate 10-mL samples of newly generated liquid low-level waste $\left(1.16 \mathrm{mg} \mathrm{Cs} / \mathrm{L}\right.$, traced with $\left.{ }^{137} \mathrm{Cs}\right)$ were gently mixed for $20 \mathrm{~h}$ with $0.0050 \mathrm{~g} \mathrm{KCCF}$. The samples were centrifuged for $30 \mathrm{~min}$ at $5000 \mathrm{rcf}$, and the ${ }^{137} \mathrm{Cs}$ count rates of the centrifuged samples were measured.

(Batch D) was comparable to that of the batches prepared with excess cobalt at either $\mathrm{pH} 11$ or $\mathrm{pH} 8$. The 20 to 50 mesh KCCF particles from the batches broke apart when in contact with the simulated NGLLLW at both $\mathrm{pH} 11$ and $\mathrm{pH}$. Centrifugation of the samples after the 20-h contact was difficult at $\mathrm{pH} 11$ because the finely divided particles tended to resuspend; the aluminum hydroxide precipitate aided in flocculation at $\mathrm{pH} 8$. Centrifuging the samples twice (centrifugation followed by decantation and centrifugation of the decanted solution) did not affect the count rates of the samples significantly. Although the reference KCCF did not break apart in contact with the simulated NGLLLW at $\mathrm{pH} 11$ or $\mathrm{pH} \mathrm{8,} \mathrm{it} \mathrm{broke} \mathrm{apart} \mathrm{physically} \mathrm{and} \mathrm{decomposed} \mathrm{in} \mathrm{previous} \mathrm{tests}$ with simulated supernate at $\mathrm{pH} 13$ (ref. 16). The lower cesium sorption power and inconsistencies in different batches make the granular KCCF less attractive than KCCF slurry for treatment of NGLLLW. The lack of physical integrity makes the granular $\mathrm{KCCF}$ undesirable for use in a column. 


\subsection{Cesium Removal from Simulated MVST Supernate}

In situ KCCF slurry also removed cesium from simulated MVST supernate at pH 8, but less effectively than from simulated NGLLLW (Fig. 7.10). Higher KCCF dose rates were needed to remove cesium from the simulated supernate. The simulated supernate has a composition that is approximately the same as that of the supernate in MVST W-29 (ref. 3). As shown in Table 4.1, it has a much higher salt content than the NGLLLW and contains potassium, which is not present in the simulated NGLLLW and which is the most likely cause for the lower cesium sorption from the simulated supernate. The simulated supernate contains about 17 times less cesium than the NGLLLW ( $0.069 \mathrm{mg} / \mathrm{L}$ compared with $1.16 \mathrm{mg} / \mathrm{L}$ ). The highest KCCF addition in the isotherm (500 $\mathrm{ppm}$ ) reduced the cesium concentration by a factor of about 850 . The maximum loading of the KCCF from the simulated supernate was about $2.6 \mathrm{meq} / \mathrm{kg}$, only about $0.05 \%$ of theoretical.

The volume of simulated supernate samples has been reduced by as much as $30 \%$ without solids formation in simulated ITE and out-of-tank evaporation tests. ${ }^{16}$ As shown in Fig. 7.10, increasing the concentration of salts in simulated supernate by $30 \%$ had little effect on cesium sorption with in situ KCCF slurry. Although cesium sorption from the simulated supernate was less effective than from simulated NGLLLW, it should be possible to blend supernate with NGLLLW for processing to reduce the volume of supernate in the storage tanks.

The KCCF-cesium complex formed by treating simulated supernate adjusted to $\mathrm{pH} 8$ with $200 \mathrm{ppm}$ in situ KCCF slurry was stable for 22 days (Fig. 7.11). Decontamination factors of over 200 were measured after one-half hour of mixing on the Labquake shaker and remained at that level throughout the test. The maximum decontamination factors were between 400 and 500 after 1 to $6 \mathrm{~h}$ of contact. Cesium sorption was more rapid at shorter contact times from the simulated supernate than from the simulated NGLLLW because of the higher KCCF dose rate used with the simulated supernate. 


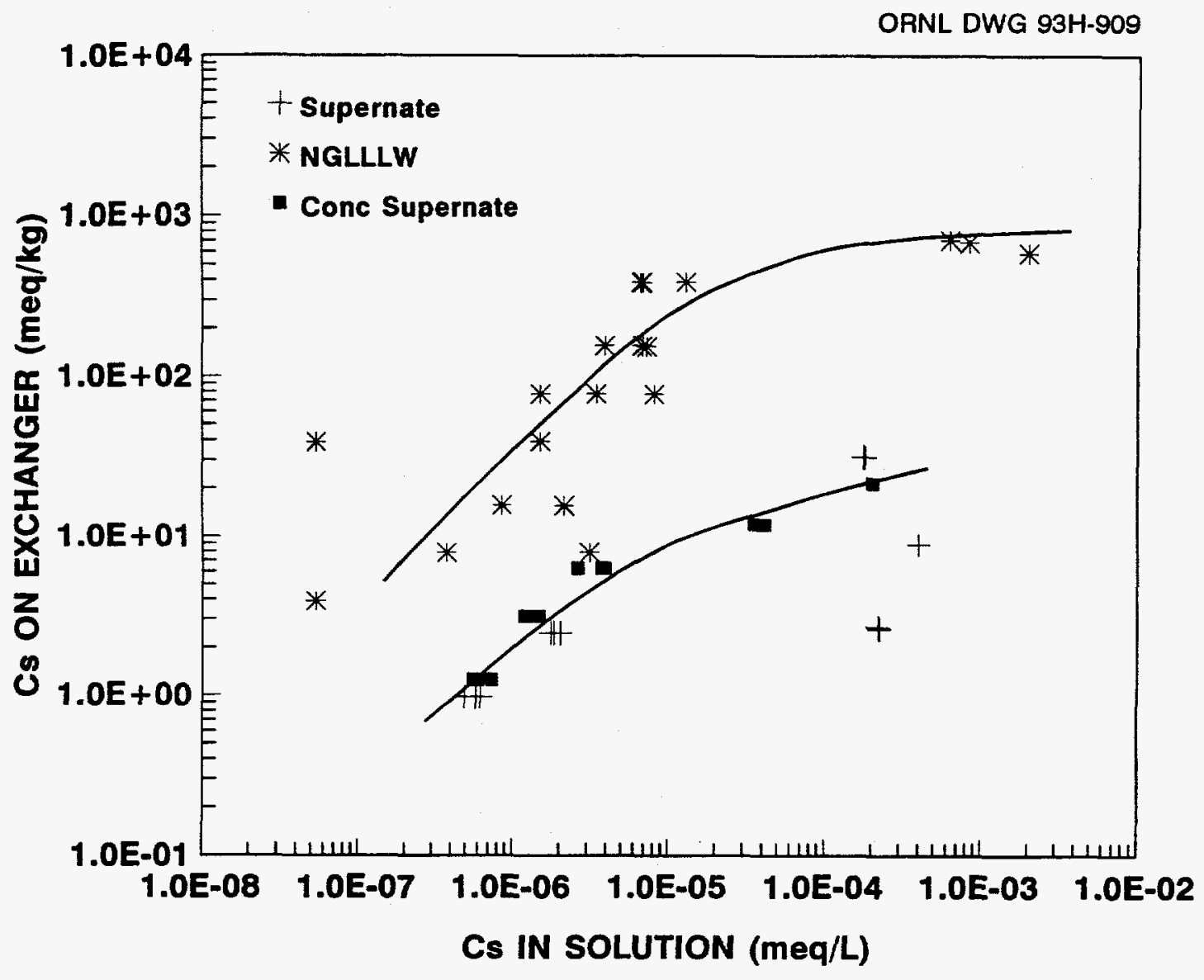

Fig. 7.10. Cesium sorption from simulated Melton Valley Storage Tank (MVST) supernates with in situ KCCF slurry. Procedure: Simulated newly generated liquid low-level waste (NGLLLW) $\left(1.16 \mathrm{mg} \mathrm{Cs} / \mathrm{L}\right.$, traced with $\left.{ }^{137} \mathrm{Cs}\right)$ or simulated MVST supernate $(0.069 \mathrm{mg}$ $\mathrm{Cs} / \mathrm{L}$, traced with ${ }^{137} \mathrm{Cs}$ ) was adjusted to $\mathrm{pH} 8$ with $5.4 \mathrm{~N} \mathrm{HCl}$, and sets of three samples of the adjusted solution were mixed for $20 \mathrm{~h}$ on a Labquake shaker with in situ KCCF slurry. The samples were centrifuged for $30 \mathrm{~min}$ at $5000 \mathrm{rcf}$, and the ${ }^{137} \mathrm{Cs}$ count rates of the centrifuged solutions were measured. 


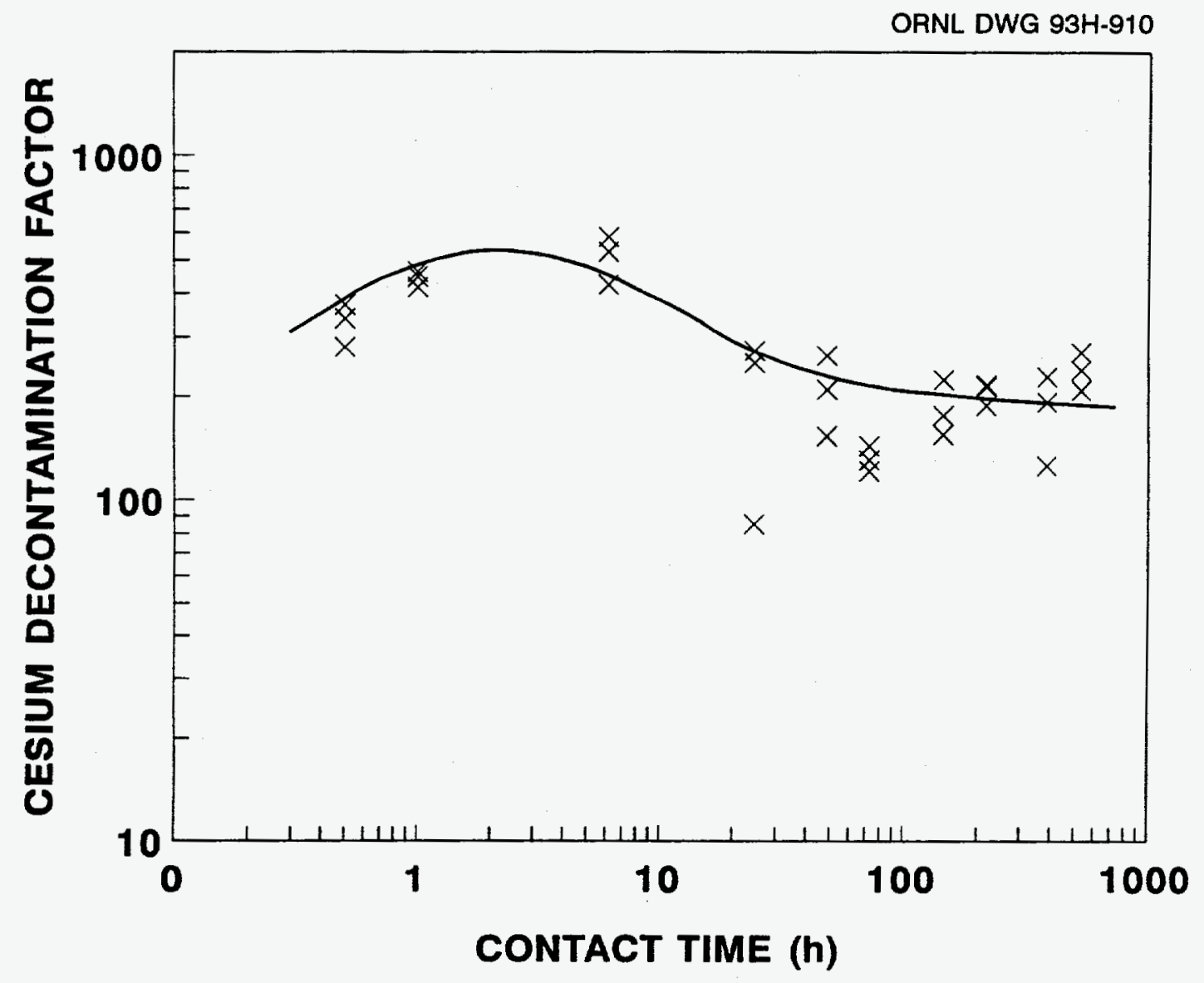

Fig. 7.11. Effect of mixing time on cesium sorption from simulated Melton Valley Storage Tank (MVST) supernate with in situ KCCF slurry. Procedure: Simulated MVST supernate $\left(0.069 \mathrm{mg} \mathrm{Cs} / \mathrm{L}\right.$, traced with $\left.{ }^{137} \mathrm{Cs}\right)$ was adjusted to $\mathrm{pH} 8$ with $5.4 \mathrm{~N} \mathrm{HCl}$, and sets of three samples were mixed for $20 \mathrm{~h}$ on a Labquake shaker with $200 \mathrm{ppm}$ in situ KCCF slurry. The samples were centrifuged for $30 \mathrm{~min}$ at $5000 \mathrm{rcf}$, and the ${ }^{137} \mathrm{Cs}$ count rates of the centrifuged solutions were measured. 


\subsection{Cesium Sorption with Other Exchangers}

Composite microspheres containing $14.5 \%$ NCCF embedded in hydrous titanium oxide (HTiO) were prepared by J. L. Collins et al., using the internal gelation process. Dried microspheres with average particle diameters of 750 and $1200 \mu \mathrm{m}$ were tested for strontium and cesium sorption from simulated NGLLLW that had been centrifuged to remove solids after $\mathrm{pH}$ adjustment to 8 . The anticipated use of the microspheres would be in a column polishing step after the bulk of the cesium had been removed in a first strike with in situ KCCF. Cesium sorption with the $750-\mu \mathrm{m}$ beads was slightly more effective than with the $1200-\mu \mathrm{m}$ beads. However, sorption with neither of the batches was as effective as with in situ KCCF slurry. Decontamination factors were a factor of 60 lower and the indicated saturation loading at $\mathrm{pH} 8$ was more than 5000 times lower, because the microspheres contained less hexacyanoferrate than the slurries and probably because of slower kinetics with the microspheres. No measurable strontium sorption occurred on the HTiO with either batch of the microspheres.

Cesium and strontium sorption measurements were made with two batches of a resorcinol-based ion-exchange resin developed at SRS. The resin, a condensation product of the potassium salt of resorcinol and an aqueous solution of formaldehyde, is being considered as a backup to the tetraphenylborate precipitation process for treatment of alkaline wastes at SRS. ${ }^{8}$ It was used in earlier studies at ORNL. ${ }^{27}$ Batch A was 20 to 50 mesh material that had been obtained from SRS several years ago. Batch B was from a drum of the resin recently obtained from SRS. This material was near 20 to 50 mesh and was used as-received. Sorption measurements were made with the two resin batches from simulated NGLLLW at $\mathrm{pH} 13$ and from simulated supernate at $\mathrm{pH} 12.7$. Under optimum $\mathrm{pH}$ conditions (13 for resin, 8 for KCCF slurry), both batches of the resin were much less effective for cesium sorption than KCCF slurry (Fig. 7.12). The indicated maximum loading of the resin was a factor of 70 lower and the decontamination factor with the same amount of exchanger was at least a factor of 1000 lower. Resin Batch B was more effective than Batch $\mathrm{A}$ for cesium removal from NGLLLW at $\mathrm{pH}$. The cesium sorption power of Batch A from simulated supernate was lower than obtained in an earlier ORNL 
ORNL DWG $93 \mathrm{H}-918$
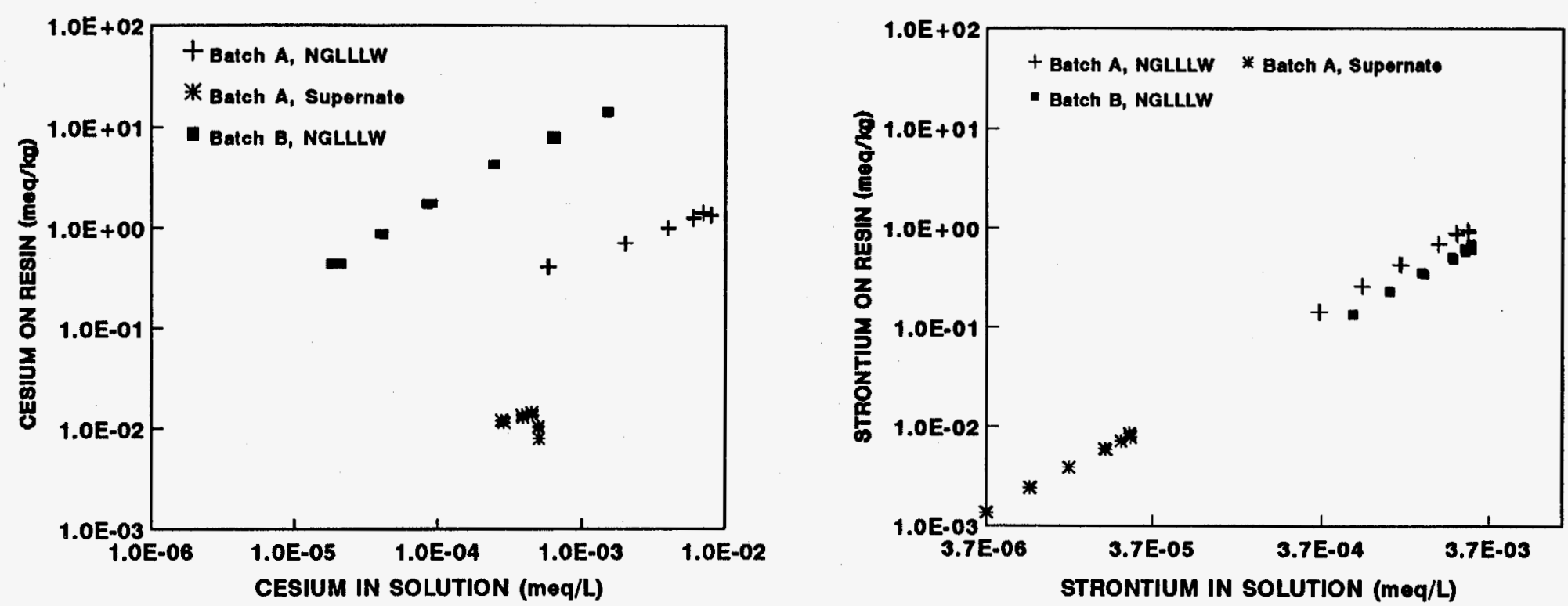

Fig. 7.12. Cesium and strontium sorption from simulated newly generated liquid low-level waste (NGLLLW) and simulated Melton Valley Storage Tank (MVST) supernate with Savannah River Site resin. Procedure: Savannah River Site resin was washed sequentially in a small column with 20 volumes of $2 M$ formic acid, 20 volumes of $\mathrm{H}_{2} \mathrm{O}, 30$ volumes of $0.25 \mathrm{M} \mathrm{NaOH}$, and 30 volumes of $\mathrm{H}_{2} \mathrm{O}$ and then air dried. Sets of three samples of simulated NGLLLW $\left(1.16 \mathrm{mg} \mathrm{Cs} / \mathrm{L}, 0.141 \mathrm{mg} \mathrm{Sr} / \mathrm{L}\right.$, traced with ${ }^{137} \mathrm{Cs}$ and ${ }^{85} \mathrm{Sr}$ ) or simulated MVST supernate $\left(0.069 \mathrm{mg} \mathrm{Cs} / \mathrm{L}, 0.0014 \mathrm{mg} \mathrm{Sr} / \mathrm{L}\right.$, traced with ${ }^{137} \mathrm{Cs}$ and $\left.{ }^{85} \mathrm{Sr}\right)$ were mixed with the pretreated resin for $20 \mathrm{~h}$ on a Labquake shaker. The samples were centrifuged for $30 \mathrm{~min}$ at $5000 \mathrm{rcf}$, and the ${ }^{137} \mathrm{Cs}$ and ${ }^{85} \mathrm{Sr}$ count rates of the centrifuged samples were measured. 
study, ${ }^{2}$ which indicates deterioration of the resin with age. With Batch A, cesium sorption from the simulated supernate was much lower than from the simulated NGLLLW. The relative positions of the equilibrium lines for the isotherms indicate that the solution composition as well as the cesium concentration affects cesium sorption with the resin. The resin sorbed strontium from simulated NGLLLW and simulated supernate, but not as strongly as other exchangers described in Sect. 6. Little difference in strontium sorption from simulated NGLLLW was found with the two resin batches, which indicates that the age of the resin did not affect strontium sorption as it did cesium sorption. With resin Batch $A$, the equilibrium line for the strontium isotherm with simulated supernate would fit a linear extrapolation of the equilibrium line with simulated NGLLLW. This shows that solution composition does not significantly affect strontium sorption with the resin. The resins were pretreated before use in the sorption tests with 20 volumes of $1 \mathrm{M} \mathrm{HCl}$, 20 volumes of $1 \mathrm{M} \mathrm{NaOH}$, and 40 volumes of water. When any of the solutions or the simulated waste solutions were contacted with the resin, a brown-yellow solution resulted, the intensity of which depended on the relative amounts of resin and solution used.

Several other exchangers were tested for cesium sorption from NGLLLW under a variety of conditions. None of them were effective. Neither zirconium phosphate nor titanium phosphate microspheres removed any cesium from simulated NGLLLW at pH 8. Decontamination factors measured with 2000 ppm of Ionsiv IE-96, a synthetic chabazite zeolite, were 2.3 at $\mathrm{pH} 11$ and 4.1 at $\mathrm{pH}$ 8. The decontamination factor with $5000 \mathrm{ppm}$ of Duolite CS-100, a phenolic cation-exchange resin, increased from 1.5 at $\mathrm{pH} 11$ to 2.4 at $\mathrm{pH}$ 13.1. The decontamination factor with $500 \mathrm{ppm}$ of ammonium molybdophosphate (Bio-Rad) increased from 1 at $\mathrm{pH} 7.2$ or $\mathrm{pH} 5.6$ to 20 at $\mathrm{pH} 1.0$.

\section{RUTHENIUM REMOVAL TEST RESULTS}

As shown in Table 2.1, ruthenium is expected to be the dominant radionuclide in newly generated waste in terms of the amount of activity present. The species of ruthenium that will be present in the newly generated waste have not been determined at this time. Our experimental work on ruthenium removal so far has been with simulated NGLLLW to which the stable ruthenium and the ruthenium tracer were added as the 
trichloride. The simulated waste contained $0.0337 \mathrm{mg} / \mathrm{L}$ of stable $\mathrm{Ru}$, equivalent to $132 \mathrm{mCi} / \mathrm{L}$ of ${ }^{106} \mathrm{Ru}$, and was traced with ${ }^{106} \mathrm{Ru}$.

Part of the ruthenium was removed from simulated NGLLLW when the $\mathrm{pH}$ was adjusted to 8 (Fig. 8.1). The removal mechanism is unknown, though it is surmised to occur as a result of either ruthenium hydroxide formation and/or sorption on $\mathrm{Al}(\mathrm{OH})_{3}$ which precipitates between $\mathrm{pH} 8$ and 10. Maximum removal occurred at $\mathrm{pH} 10$, where a decontamination factor of 5 ( $80 \%$ removal) was measured. The decontamination factor was about 3 in the $\mathrm{pH}$ range 7-9, and little ruthenium was removed from the solution at $\mathrm{pH}$ 11-13. Ruthenium removal was measured in these tests by adjusting the $\mathrm{pH}$ of simulated NGLLLW, with the samples taken at different $\mathrm{pH}$ levels being centrifuged before measurement of ruthenium concentration.

In a study by Beaven et al., ${ }^{17}$ transition-metal hexacyanoferrates, cobalt sulfide, and manganese dioxide were shown to be effective for ruthenium removal from $1 \mathrm{~mol} / \mathrm{L}$ $\mathrm{NaNO}_{3}$. Ames ${ }^{18}$ reported $80 \%$ ruthenium removal from $1 \mathrm{~mol} / \mathrm{L} \mathrm{NaNO} \mathrm{Na}_{3}$ at $\mathrm{pH} 3.5$ by adding soluble ferrous salts and passing the solution through a bed of calcite. The results of our sorption tests with these exchangers are shown in Fig. 8.2. Based on the amount of exchanger used, soluble iron salts added to the alkaline waste solution to form in situ iron hydroxide precipitates were the most effective exchangers tested. Ferric sulfate was slightly more effective than ferrous sulfate, although the precipitate in both cases appeared to be ferric hydroxide. With only $25 \mathrm{ppm}$ iron added, the decontamination factor with ferric sulfate was about 45 and about 35 with $\mathrm{FeSO}_{4}$. Maximum removal with the iron salts occurred at $\mathrm{pH} 10.5$ to 11 . A maximum decontamination factor of about 50 was measured from simulated NGLLLW at $\mathrm{pH} 11$ with $1000 \mathrm{ppm}$ of KCCF added as in situ slurry. A decontamination factor of 10 was measured at $\mathrm{pH} 11$ with $100 \mathrm{ppm}$ KCCF. Maximum sorption on cobalt sulfide or manganese dioxide occurred at $\mathrm{pH} 10$. The decontamination factors with $500 \mathrm{ppm}$ exchanger were about 35 for CoS and about 25 for $\mathrm{MnO}_{2}$. For all of the exchangers, the decontamination factors include the amount of ruthenium removed by $\mathrm{pH}$ adjustment as well as the amount sorbed on the exchangers. 


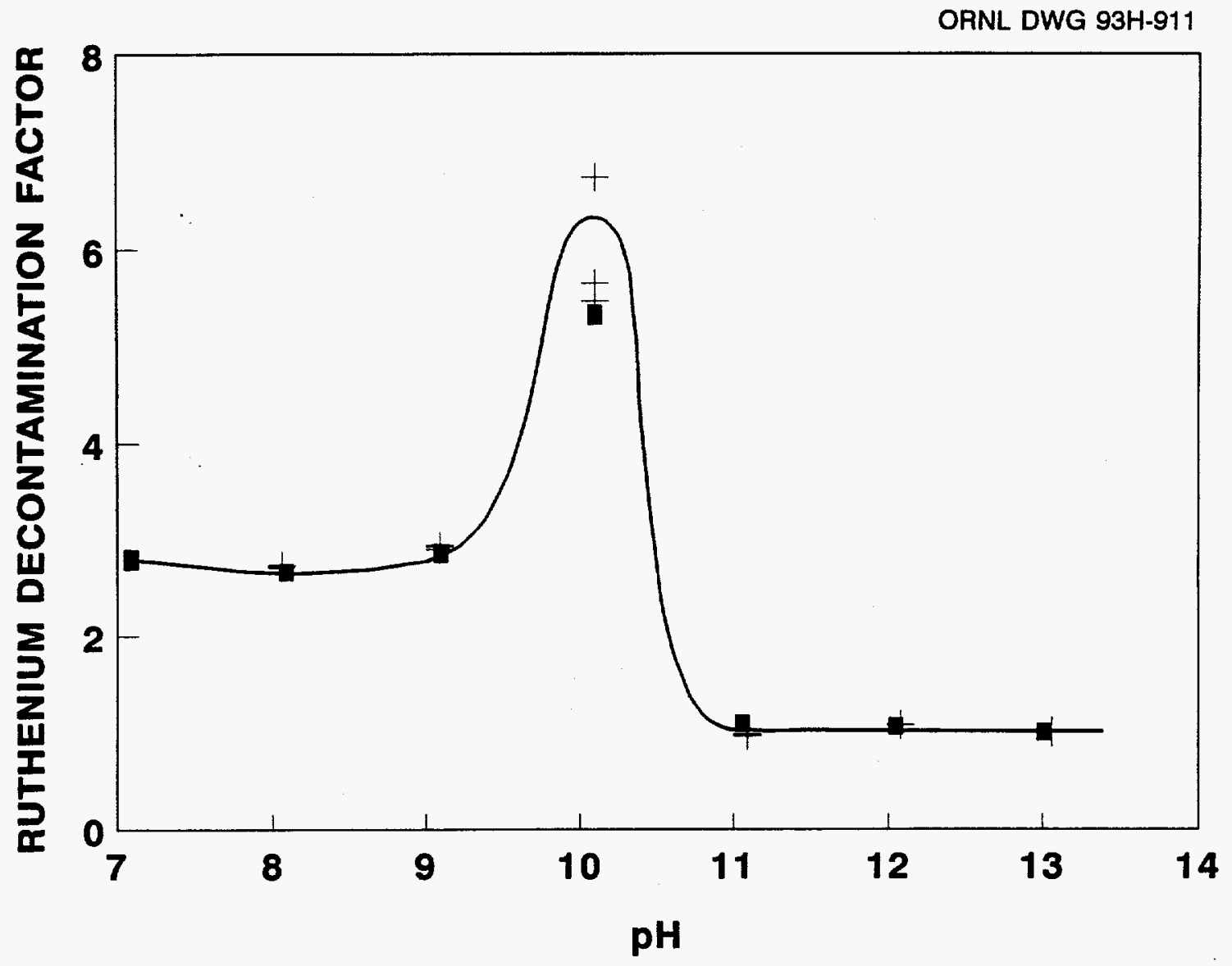

Fig. 8.1. Ruthenium removal from simulated newly generated liquid low-level waste (NGLLLW) during pH adjustment. Procedure: The $\mathrm{pH}$ of simulated NGLLLW $(0.0337 \mathrm{mg}$ $\mathrm{Ru} / \mathrm{L}$, traced with ${ }^{106} \mathrm{Ru}$ ) was adjusted with $5.4 \mathrm{~N} \mathrm{HCl}$ and centrifuged for 30 min at $5000 \mathrm{rcf}$. The ${ }^{106} \mathrm{Ru}$ count rates of the centrifuged solutions were measured. 


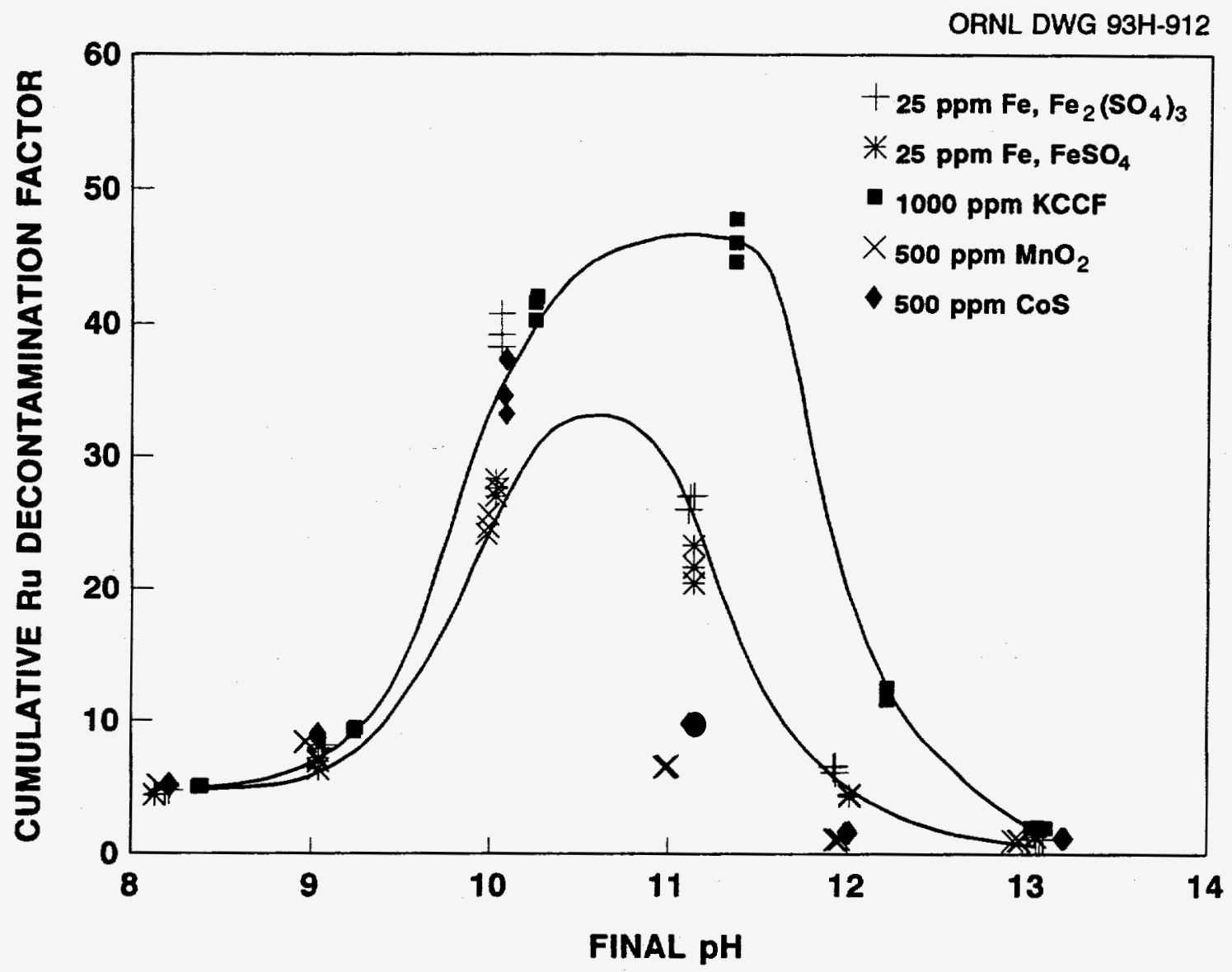

Fig. 8.2. Effect of pH on ruthenium removal from simulated newly generated liquid low-level waste (NGLLLW). Procedure: The $\mathrm{pH}$ of simulated NGLLLW $(0.0337 \mathrm{mg} \mathrm{Ru} / \mathrm{L}$, traced with ${ }^{106} \mathrm{Ru}$ ) was adjusted with $5.4 \mathrm{~N} \mathrm{HCl}$. Sets of three samples of the adjusted solutions were mixed for $20 \mathrm{~h}$ on a Labquake shaker with the exchangers. The samples were centrifuged for $30 \mathrm{~min}$ at $5000 \mathrm{rcf}$, and the ${ }^{106} \mathrm{Ru}$ count rates of the centrifuged solutions were measured. 
In a sorption isotherm with ferric sulfate at $\mathrm{pH} 11$, increasing the amount of added iron resulted in increased decontamination factors but not in proportion to the iron addition (Fig. 8.3). The decontamination factor increased from 22 when $10 \mathrm{ppm}$ iron was added to simulated NGLLLW to 32 with $50 \mathrm{ppm}$ iron, to 36 with $100 \mathrm{ppm}$ iron, to 39 with $200 \mathrm{ppm}$ iron, and to 44 with $500 \mathrm{ppm}$ iron. The $\mathrm{pH}$ of the solution after treatment with iron dropped as the amount of ferric sulfate was increased, from 11.2 with $10 \mathrm{ppm}$ iron to 10.5 with $200 \mathrm{ppm}$ iron. Plotting the results of this test as ruthenium concentration on the $\mathrm{Fe}(\mathrm{OH})_{3}$ against the ruthenium concentration remaining in solution suggests the presence of more than one ruthenium complex in the simulated NGLLLW (Fig. 8.4). The initial ruthenium concentration of the simulated NGLLLW was about $3.7 \times 10^{-7} \mathrm{~mol} / \mathrm{L}$, and the maximum ruthenium loading of the $\mathrm{Fe}(\mathrm{OH})_{3}$ was not reached in the sorption tests. The equilibrium line for the isotherm is very steep, and the concentration of ruthenium in the solution decreased only slightly with increasing iron additions. This could be due to the presence of ruthenium species in the solution that are sorbed on the $\mathrm{Fe}(\mathrm{OH})_{3}$ and others that are not. Imai et al. ${ }^{19}$ reported that precipitation of ferric hydroxide at $\mathrm{pH} 9$ precipitates chloro complexes of ruthenium but does not remove ruthenium present as nitrate or nitrosyl complexes. Further work is needed with simulated waste solutions that contain the ruthenium species expected in actual waste solutions.

\section{NITRATE DESTRUCTION}

In order to discharge treated MVST supernate to the process waste system, most of the nitrate in the supernate will need to be removed. Progress is being monitored in the development of several new technologies. This work is primarily supported by the U.S. Department of Energy's Office of Technology Development, through the Chemical/Physical Technology Support Group of the Mixed Waste Integrated Program. Two technologies that appear to have promise for treating the nitrate in the MVST supernate are the nitrate to ammonia and ceramic (NAC) process being developed at ORNL and the electrochemical destruction processes being developed by several companies.

The NAC process involves the chemical reduction of nitrate ions to ammonia by powdered aluminum. This process occurs in alkaline solutions $(\mathrm{pH}>11.5)$ at slightly 


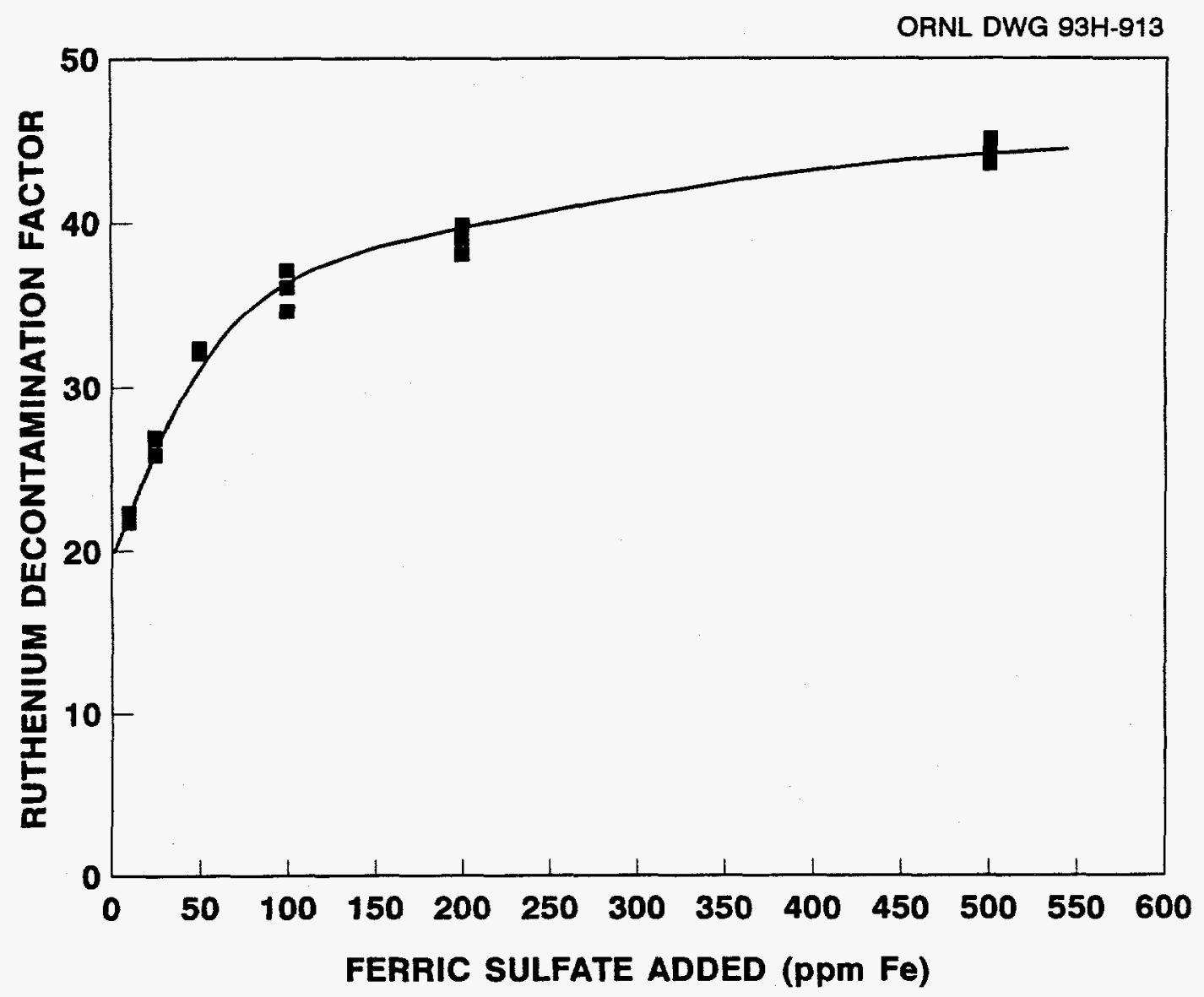

Fig. 8.3. Ruthenium removal from simulated newly generated liquid low-level waste (NGLLLW) with ferric sulfate. Procedure: The $\mathrm{pH}$ of simulated NGLLLW $(0.0337 \mathrm{mg}$ $\mathrm{Ru} / \mathrm{L}$, traced with ${ }^{106} \mathrm{Ru}$ ) was adjusted with $5.4 \mathrm{~N} \mathrm{HCl}$. Sets of three samples of the adjusted solutions were mixed for $20 \mathrm{~h}$ on a Labquake shaker with $25 \mathrm{ppm} \mathrm{Fe}{ }^{3+}$, added as ferric sulfate. The solutions were centrifuged for $30 \mathrm{~min}$ at $5000 \mathrm{rcf}$, and the ${ }^{106} \mathrm{Ru}$ count rates of the centrifuged solutions were measured. 


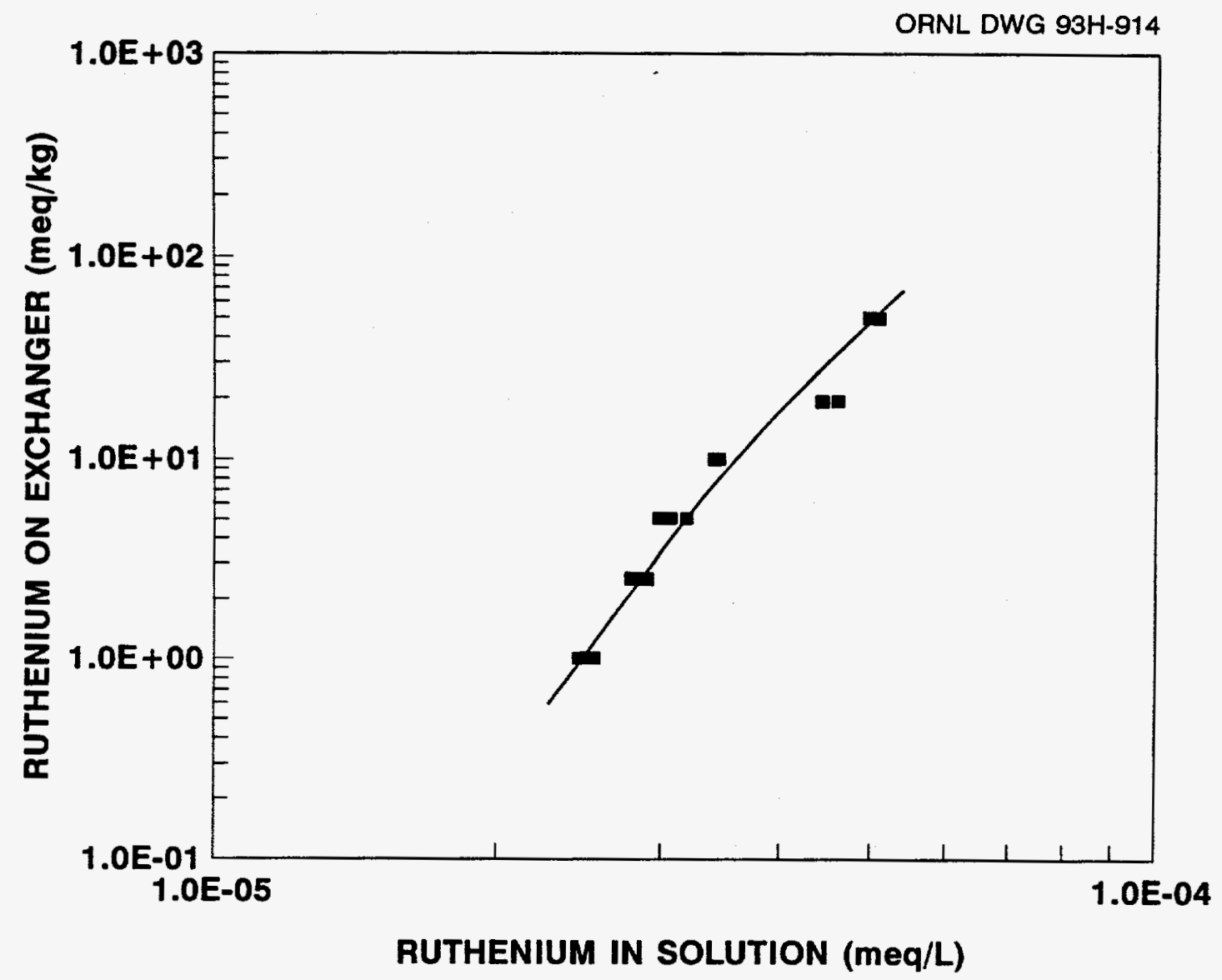

Fig. 8.4. Isotherm for ruthenium removal from simulated newly generated liquid lowlevel waste (NGLLLW) with ferric sulfate. Procedure: Simulated NGLLLW $(0.0337 \mathrm{mg}$ $\mathrm{Ru} / \mathrm{L}$, traced with ${ }^{106} \mathrm{Ru}$ ) was adjusted to $\mathrm{pH} 11$ with $5.4 N \mathrm{HCl}$. Sets of three samples of the adjusted solution were mixed for $20 \mathrm{~h}$ on a Labquake shaker with ferric sulfate. The samples were centrifuged for $30 \mathrm{~min}$ at $5000 \mathrm{rcf}$, and the ${ }^{106} \mathrm{Ru}$ count rates of the adjusted solutions were measured. 
elevated temperatures $\left(>50^{\circ} \mathrm{C}\right)$. The reaction produces a granular, sandlike material that can be dried, pressed, and sintered to form an insoluble alumina-silica ceramic as the final waste form. Silica is added to the reactor to immobilize the sodium in the ceramic waste form. The volume of the final solid waste form will be about $70 \%$ less than the starting solution for a $4 \mathrm{M} \mathrm{NaNO}_{3}$ solution. The aluminum hydroxide will coprecipitate and/or adsorb many inorganic contaminants such as heavy metals and ${ }^{90} \mathrm{Sr}$ from the waste solution, which will be incorporated into the insoluble final waste form.

Electrochemical destruction of nitrate- and nitrite-containing mixed wastes shows promise in reducing the volume of residual wastes in effluent waste streams as well as being competitive with other wet processing approaches, at least on the basis of power consumption. This method of destroying nitrates is under development by Bradtec, Inc., (Bristol, United Kingdom) and AEA Industrial Technology (Oxfordshire, United Kingdom) as well as by researchers at SRS; it has been tested on simulants for radioactive waste streams expected at the Rocky Flats Plant and SRS. Bradtec's electrochemical ionexchange (EIX) process consists of separation of the nitrate from the waste stream by an anion-exchange resin followed by migration of the nitrate anions to an anode. The nitrate can be recovered as nitric acid or destroyed in an electrochemical cell to produce nitrogen and ammonia. The other companies are focusing on the electrochemical destruction process.

Demonstration of these technologies on the MVST supernate will be considered in the future if it appears likely that the ${ }^{106} \mathrm{Ru}$ in the NGLLLW can be reduced to meet the waste acceptance requirements for the process waste system.

\section{FLOWSHEET DEVELOPMENT}

The most effective treatment flowsheet for simulated NGLLLW in removal of Sr, $\mathrm{Cs}$, and $\mathrm{Ru}$ at this stage of development is as shown in Fig. 10.1. It includes the following steps. 


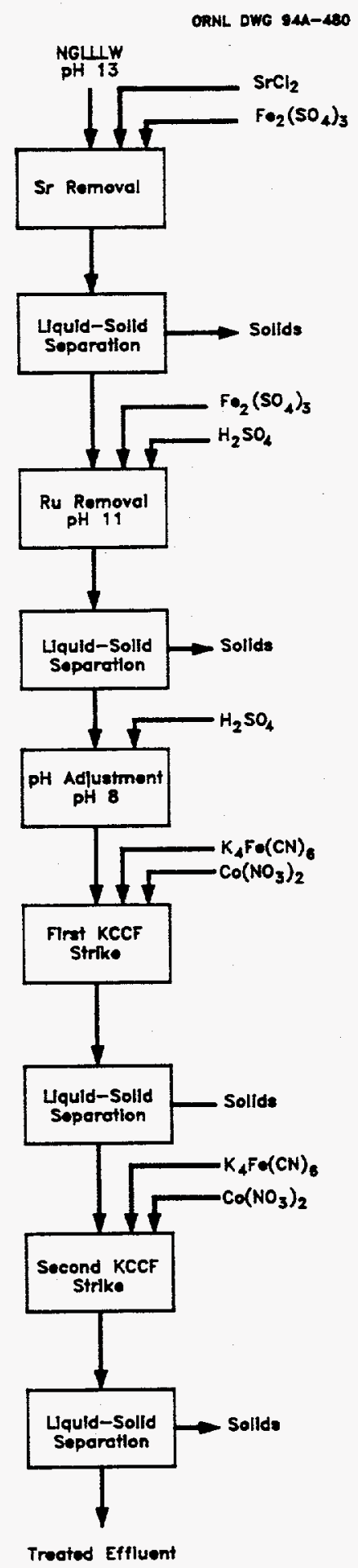

Fig. 10.1. Flowsheet for treatment of simulated newly generated liquid low-level waste (NGLLLW). 
1. Strontium removal at $\mathrm{pH} 13$ by coprecipitation with stable strontium added to the solution as $\mathrm{SrCl}_{2}$. Ferric sulfate solution can be added in this step to provide additional strontium removal and to aid in flocculation of the solids, which are separated from the solution at $\mathrm{pH}$ 13. Additional decontamination of strontium occurs by sorption on the $\mathrm{Al}(\mathrm{OH})_{3}$ that precipitates at about $\mathrm{pH} 10$. Details of this part of the flowsheet are described in Sect. 6.

2. Adjustment of the $\mathrm{pH}$ to 11 to remove 80 to $90 \%$ of the ruthenium by sorption onto ferric hydroxide produced by adding the ferric sulfate solution. At this stage, ruthenium behavior has been studied only as the trichloride, and more complicated species are expected to be present in the waste solutions. Additional work using more complex ruthenium species will be needed to define this part of the processing flowsheet. Limited success has been obtained with ruthenium sorption on the exchangers tested so far. A liquid-solid separation at $\mathrm{pH} 11$ was needed because removal was less effective at other $\mathrm{pH}$ levels.

3. Adjustment to $\mathrm{pH} 8$ and cesium removal on $\mathrm{KCCF}$ slurry, either preformed or formed in place. Two KCCF strikes, with a liquid-solid separation after each, are needed to ensure that the required decontamination is achieved. The $\mathrm{Al}(\mathrm{OH})_{3}$ that precipitates during $\mathrm{pH}$ adjustment aids in flocculation of the precipitate in the first KCCF strike, and the second strike is made on the clarified solution from the first strike. Details of treatment for cesium removal are described in Sect. 7.

\section{FLOWSHEET DEMONSTRATION}

Several laboratory-scale tests were made to demonstrate the flowsheet at the current stage of development for $\mathrm{Sr}, \mathrm{Cs}$, and $\mathrm{Ru}$ removal from simulated NGLLLW. The required decontamination factors for strontium and cesium were exceeded in these tests, but the ruthenium decontamination factors were much too low. After the laboratory-scale tests, continuous tests to demonstrate strontium and cesium removal processes were 
conducted using a $500 \mathrm{~mL} / \mathrm{min}$ pilot-scale test system. Pilot-scale tests to demonstrate ruthenium removal will be made when more effective treatment methods have been developed.

The first of the laboratory-scale demonstration tests included a strike with $50 \mathrm{ppm}$ stable strontium $\left(\mathrm{SrCl}_{2}\right)$ and a liquid-solid separation at $\mathrm{pH} \mathrm{13,} \mathrm{followed} \mathrm{by} \mathrm{adjustment} \mathrm{to}$ pH 8. Cesium was then removed in two strikes with in situ KCCF slurry, the first with $100 \mathrm{ppm} \mathrm{KCCF}$ and the second with $50 \mathrm{ppm}$. The liquid-solid separations after the $\mathrm{SrCl}_{2}$ strike and the two KCCF strikes were by centrifugation for $30 \mathrm{~min}$ at $5000 \mathrm{rcf}$. The simulated NGLLLW, prepared from process water, contained stable ruthenium but not ${ }^{106} \mathrm{Ru}$ tracer. The required decontamination factors for both strontium and cesium were exceeded in the test (Table 11.1). The strontium decontamination factor was 32 in the $\mathrm{SrCl}_{2}$ strike and slightly more than 5 during $\mathrm{pH}$ adjustment, for a cumulative process decontamination factor of 160 . The cesium concentration was reduced by a factor of 2000 in the first KCCF strike but only by a factor of about 39 in the second, for a cumulative decontamination factor of 95000 . The low efficiency in the second KCCF strike was possibly due to difficulty in the liquid-solid separation.

As was shown in Sect. 8, maximum ruthenium removal from simulated NGLLLW occurs with ferric sulfate addition at $\mathrm{pH} 11$. About $90 \%$ of the ruthenium was removed from simulated NGLLLW along with the strontium and cesium by making the strike with $\mathrm{SrCl}_{2}+$ ferric sulfate at $\mathrm{pH} 11$ instead of at $\mathrm{pH} 13$, followed by adjusting the solution to pH 8 and making two strikes with in situ KCCF slurry (Table 11.2). The ruthenium decontamination factor was 5.6 in the $\mathrm{SrCl}_{2}$ strike and 1.6 during adjustment to $\mathrm{pH} 8$. Small amounts of ruthenium were removed from the solution in each of the KCCF strikes for a process decontamination factor of slightly more than 10. Strontium decontamination factors of 46 for the $\mathrm{SrCl}_{2}$ strike and 240 for the process were measured. The strontium decontamination factors, both for the $\mathrm{SrCl}_{2}$ strike and for the process, were higher than in the test at $\mathrm{pH} 13$ because of the addition of ferric sulfate and because of better mixing in the $\mathrm{SrCl}_{2}$ strike. The efficiency of strontium removal in this step depends on rapidly dispersing the $\mathrm{SrCl}_{2}$ solution throughout the NGLLLW so that localized precipitation is avoided and uniform precipitation of the stable strontium and radioactive strontium 
Table 11.1. Strontium and cesium removal from simulated newly generated liquid low-level waste (NGLLLW) with a $\mathrm{SrCl}_{2}$ strike and two $\mathrm{KCCF}$ strikes

\begin{tabular}{|c|c|c|c|c|}
\hline \multirow[b]{2}{*}{$\begin{array}{c}\text { Unit } \\
\text { operation }\end{array}$} & \multicolumn{2}{|c|}{ Strontium decontamination factor } & \multicolumn{2}{|c|}{ Cesium decontamination factor } \\
\hline & $\begin{array}{c}\text { Unit } \\
\text { operation }\end{array}$ & Cumulative & $\begin{array}{c}\text { Unit } \\
\text { operation }\end{array}$ & Cumulative \\
\hline $\mathrm{SrCl}_{2}$ strike & $32.2 \pm 5.6$ & $32.2 \pm 5.6$ & $1.00 \pm 0.01$ & $1.00 \pm 0.01$ \\
\hline pH Adjustment & $5.2 \pm 1.1$ & $161 \pm 34$ & $1.18 \pm 0.01$ & $1.18 \pm 0.01$ \\
\hline First KCCF strike & $1.05 \pm 0.17$ & $163 \pm 27$ & $2058 \pm 417$ & $2444 \pm 725$ \\
\hline Second KCCF strike & $1.06 \pm 0.22$ & $168 \pm 36$ & $38.6 \pm 8.7$ & $95400 \pm 33600$ \\
\hline
\end{tabular}

'Procedure: $\underline{\mathrm{SrCl}}_{2}$ Strike. Triplicate samples of simulated NGLLLW $(0.141 \mathrm{mg} \mathrm{Sr} / \mathrm{L}, 1.16 \mathrm{mg} \mathrm{Cs} / \mathrm{L}$, traced with ${ }^{85} \mathrm{Sr}$ and ${ }^{137} \mathrm{Cs}$ ) were mixed for $1 \mathrm{~h}$ on a Labquake shaker with $50 \mathrm{ppm} \mathrm{Sr}$, added as $\mathrm{SrCl}_{2}$. The samples were centrifuged for $30 \mathrm{~min}$ at $5000 \mathrm{rcf}$, and the ${ }^{85} \mathrm{Sr}$ and ${ }^{137} \mathrm{Cs}$ count rates of the centrifuged solutions were measured. pH Adjustment. The centrifuged solutions were adjusted to $\mathrm{pH} 8$ with $5.1 \mathrm{~N} \mathrm{H}_{2} \mathrm{SO}_{4}$, mixed for $1 \mathrm{~h}$ on a Labquake shaker, and centrifuged for $30 \mathrm{~min}$ at $5000 \mathrm{rcf}$. The ${ }^{85} \mathrm{Sr}$ and ${ }^{137} \mathrm{Cs}$ count rates of the centrifuged solutions were measured. First KCCF Strike. The centrifuged solutions were mixed for $1 \mathrm{~h}$ on a Labquake shaker with $100 \mathrm{ppm}$ in situ KCCF slurry and centrifuged for $30 \mathrm{~min}$ at $5000 \mathrm{rcf}$. The ${ }^{85} \mathrm{Sr}$ and ${ }^{137} \mathrm{Cs}$ count rates of the centrifuged solutions were measured. Second KCCF Strike. The centrifuged solutions were mixed for $1 \mathrm{~h}$ on a Labquake shaker with $50 \mathrm{ppm}$ in situ KCCF slurry and centrifuged for $30 \mathrm{~min}$ at $5000 \mathrm{rcf}$. The ${ }^{85} \mathrm{Sr}$ and ${ }^{137} \mathrm{Cs}$ count rates of the centrifuged solutions were measured. 
Table 11.2 Removal of $\mathrm{Sr}, \mathrm{Cs}$, and $\mathrm{Ru}$ from simulated newly generated liquid low-level waste (NGLLLW) with a $\mathrm{SrCl}_{2}+$ ferric sulfate strike and two KCCF strikes

\begin{tabular}{|c|c|c|c|c|c|c|}
\hline \multirow[b]{2}{*}{$\begin{array}{c}\text { Unit } \\
\text { operation }\end{array}$} & \multicolumn{2}{|c|}{$\begin{array}{l}\text { Strontium decontamination } \\
\text { factor }\end{array}$} & \multicolumn{2}{|c|}{ Cesium decontamination factor } & \multicolumn{2}{|c|}{$\begin{array}{l}\text { Ruthenium decontamination } \\
\text { factor }\end{array}$} \\
\hline & $\begin{array}{c}\text { Unit } \\
\text { operation }\end{array}$ & Cumulative & $\begin{array}{c}\text { Unit } \\
\text { operation }\end{array}$ & Cumulative & $\begin{array}{c}\text { Unit } \\
\text { operation }\end{array}$ & Cumulative \\
\hline $\begin{array}{l}\mathrm{SrCl}_{2}+\text { ferric } \\
\text { sulfate strike }\end{array}$ & $46.3 \pm 9.8$ & $46.3 \pm 9.8$ & $1.07 \pm 0.01$ & $0.99 \pm 0.01$ & $5.58 \pm 0.38$ & $5.58 \pm 0.39$ \\
\hline pH Adjustment & $5.3 \pm 1.5$ & $232 \pm 67$ & $1.08 \pm 0.01$ & $1.17 \pm 0.01$ & $1.56 \pm 0.07$ & $8.71 \pm 0.44$ \\
\hline Second KCCF strike & $1.12 \pm 0.3$ & $243 \pm 68$ & $513 \pm 409$ & $>(2.5 \pm 1.0) \times 10^{6}$ & $1.08 \pm 0.06$ & $10.06 \pm 0.58$ \\
\hline
\end{tabular}

aProcedure: $\mathrm{SrCl}_{2}+$ Ferric Sulfate Strike. Triplicate samples of simulated NGLLLW $(0.141 \mathrm{mg} \mathrm{Sr} / \mathrm{L}, 1.16 \mathrm{mg} \mathrm{Cs} / \mathrm{L}, 0.0337 \mathrm{mg} \mathrm{Ru} / \mathrm{L}$, traced with ${ }^{85} \mathrm{Sr},{ }^{137} \mathrm{Cs}$, and ${ }^{106} \mathrm{Ru}$ ) were adjusted to $\mathrm{pH} 11$ with $5.1 \mathrm{~N} \mathrm{H}_{2} \mathrm{SO}_{4}$ and mixed for $1 \mathrm{~h}$ on a Labquake shaker with $50 \mathrm{ppm}$ strontium, added as $\mathrm{SrCl}_{2}$, and $25 \mathrm{ppm} \mathrm{Fe}{ }^{3+}$, added as ferric sulfate. The samples were centrifuged for $30 \mathrm{~min}$ at $5000 \mathrm{rcf}$, and the ${ }^{85} \mathrm{Sr}$, ${ }^{137} \mathrm{Cs}$, and ${ }^{106} \mathrm{Ru}$ count rates of the centrifuged solutions were measured. $\mathrm{pH}$ Adjustment. The centrifuged solutions were adjusted to pH 8 with $5.1 \mathrm{~N} \mathrm{H}_{2} \mathrm{SO}_{4}$, mixed for $1 \mathrm{~h}$ on a Labquake shaker, and centrifuged for $30 \mathrm{~min}$ at $5000 \mathrm{rcf}$. The ${ }^{85} \mathrm{Sr}$, ${ }^{137} \mathrm{Cs}$, and ${ }^{106} \mathrm{Ru} \mathrm{count}$ rates of the centrifuged solutions were measured. First KCCF Strike. The centrifuged solutions were mixed for $1 \mathrm{~h}$ on a Labquake shaker with $100 \mathrm{ppm} \mathrm{KCCF} \mathrm{slurry} \mathrm{and} \mathrm{centrifuged} \mathrm{for} 30 \mathrm{~min}$ at $5000 \mathrm{rcf}$. The ${ }^{85} \mathrm{Sr},{ }^{137} \mathrm{Cs}$, and ${ }^{106} \mathrm{Ru}$ count rates of the centrifuged solutions were measured. Second KCCF Strike. The centrifuged solutions were mixed for $1 \mathrm{~h}$ on a Labquake shaker with $50 \mathrm{ppm}$ $\mathrm{KCCF}$ and centrifuged for $30 \mathrm{~min}$ at $5000 \mathrm{rcf}$. The ${ }^{85} \mathrm{Sr},{ }^{137} \mathrm{Cs}$, and ${ }^{106} \mathrm{Ru}$ count rates of the centrifuged solutions were measured. 
occurs. This can be achieved by stirring the waste solution vigorously during the addition of the strike solution. Cesium behavior was not affected by the $\mathrm{pH}$ of the $\mathrm{SrCl}_{2}$ strike. The decontamination factor was 3600 in the first strike with $100 \mathrm{ppm} \mathrm{KCCF} \mathrm{and} 500$ in the second strike with $50 \mathrm{ppm} \mathrm{KCCF}$, for a process decontamination factor of $>2.5 \times$ $10^{6}$.

Testing the flowsheet at pilot scale requires passing the simulated NGLLLW solution through the system several times to demonstrate all of the processing steps. Each pass through the system requires about $6 \mathrm{~h}$, with an overnight delay between passes. This delay had no measurable effect on strontium or cesium removal in laboratory-scale tests (Table 11.3). The strontium decontamination factor in this test was improved by adding $25 \mathrm{ppm}$ iron (as ferric sulfate) to the solution in the $\mathrm{SrCl}_{2}$ strike and by adding a polymer to aid in flocculating the solids to improve the liquid-solid separation. The cesium decontamination factor in two strikes with KCCF was also increased by adding a polymer to improve flocculation. The polymer addition was particularly useful in the second KCCF strike because no $\mathrm{Al}(\mathrm{OH})_{3}$ is present to flocculate the solids as in the first strike. The flowsheet included a strike with $50 \mathrm{ppm}$ strontium $\left(\mathrm{SrCl}_{2}\right)+25 \mathrm{ppm}$ iron (ferric sulfate) and a liquid-solid separation at $\mathrm{pH} 13$ for the primary strontium removal, followed by adjustment to pH 8 and two strikes with in situ KCCF slurry. The Calgon polymers, PolE-Z 2466 for strontium and WT-2466I for cesium, were added to the waste solutions as $0.05 \%$ solutions in water. Addition rates were $2 \mathrm{ppm}$ for the $\mathrm{SrCl}_{2}$ strike and the first KCCF strike and $20 \mathrm{ppm}$ for the second KCCF strike. The polymer solutions were added at the end of the $1 \mathrm{~h}$ mixing periods for the strikes, and the solutions were mixed slowly for an additional one-half hour before centrifugation for $30 \mathrm{~min}$ at $5000 \mathrm{rcf}$. The strontium decontamination factor was 130 for the $\mathrm{SrCl}_{2}$ strike and 290 for the process, while the cesium decontamination factor was 7750 for the first KCCF strike with 100 ppm $\mathrm{KCCF}, 2985$ for the second strike with $50 \mathrm{ppm} \mathrm{KCCF}$, and $>2.3 \times 10^{7}$ for the process.

The ORNL Wastewater Treatment Test Facility (WTTF) was used to conduct the pilot-scale test of the flowsheet that is being developed for removing cesium and strontium from NGLLLW. The same batch of NGLLLW surrogate was processed through the WTTF test system three times, using different treatment chemicals, to 
Table 11.3. Effect of processing delays and coagulant polymers on strontium and cesium removal from simulated newly generated liquid low-level waste (NGLLW)

\begin{tabular}{|c|c|c|c|c|}
\hline \multirow[b]{2}{*}{$\begin{array}{c}\text { Unit } \\
\text { operation }\end{array}$} & \multicolumn{2}{|c|}{$\begin{array}{c}\text { Strontium } \\
\text { decontamination factor }\end{array}$} & \multicolumn{2}{|c|}{$\begin{array}{c}\text { Cesium } \\
\text { decontamination factor }\end{array}$} \\
\hline & $\begin{array}{c}\text { Unit } \\
\text { operation }\end{array}$ & Cumulative & $\begin{array}{c}\text { Unit } \\
\text { operation }\end{array}$ & Cumulative \\
\hline$\underset{\text { strike }}{\mathrm{SrCl}_{2}}+$ ferric sulfate & $132 \pm 14$ & $132 \pm 14$ & NA & NA \\
\hline pH Adjustment & $2.5 \pm 0.3$ & $327 \pm 44$ & NA & NA \\
\hline First KCCF strike & $1.0 \pm 0.1$ & $305 \pm 17$ & $7750 \pm 544$ & $7750 \pm 544$ \\
\hline Second KCCF strike & $0.9 \pm 0.2$ & $291 \pm 49$ & $2985 \pm 221$ & $(23.4 \pm 0.1) \times 10^{6}$ \\
\hline
\end{tabular}

${ }^{a} \mathrm{NA}$ indicates stable cesium added to initial feed, ${ }^{137} \mathrm{Cs}$ tracer added at beginning of first KCCF strike. "Procedure: $\mathrm{SrCl}_{2}+$ Ferric Sulfate Strike. Simulated NGLLLW $(0.141 \mathrm{mg} \mathrm{Sr} / \mathrm{L}, 1.16 \mathrm{mg} \mathrm{Cs} / \mathrm{L}$, traced with ${ }^{85} \mathrm{Sr}$ ) was mixed for $1 \mathrm{~h}$ on a magnetic stirrer with $50 \mathrm{ppm}$ strontium, added as $\mathrm{SrCl}_{2}$, and $25 \mathrm{ppm} \mathrm{Fe}^{3+}$, added as ferric sulfate. Then 2 ppm of Calgon Pol-E-Z-2466 was added, and the samples were mixed for an additional $30 \mathrm{~min}$. The samples were centrifuged for $30 \mathrm{~min}$ at $5000 \mathrm{rcf}$, and the ${ }^{85} \mathrm{Sr}$ count rates of the centrifuged solutions were measured. $\mathrm{pH}$ Adjustment. The centrifuged samples were stirred overnight, adjusted to $\mathrm{pH} 8$ with $5.4 \mathrm{~N} \mathrm{H}_{2} \mathrm{SO}_{4}$, and centrifuged for $30 \mathrm{~min}$ at $5000 \mathrm{rcf}$. The ${ }^{85} \mathrm{Sr}$ count rates of the centrifuged samples were measured. First KCCF Strike. The centrifuged samples were stirred overnight, traced with ${ }^{137} \mathrm{Cs}$, and mixed for $1 \mathrm{~h}$ on a Labquake shaker with $100 \mathrm{ppm}$ in situ KCCF slurry. Then $2 \mathrm{ppm}$ Calgon WT-2466I polymer was added, and the samples were mixed for an additional 30 min and centrifuged for $30 \mathrm{~min}$ at $5000 \mathrm{rcf}$. The ${ }^{85} \mathrm{Sr}$ and ${ }^{137} \mathrm{Cs}$ count rates of the centrifuged solutions were measured. Second KCCF Strike. The centrifuged samples were stirred overnight and mixed for $1 \mathrm{~h}$ on a Labquake shaker with $50 \mathrm{ppm}$ in situ KCCF slurry. Then $20 \mathrm{ppm}$ Calgon WT-2466I polymer was added, and the samples were mixed for an additional $30 \mathrm{~min}$ and centrifuged for $30 \mathrm{~min}$ at $5000 \mathrm{rcf}$. The ${ }^{85} \mathrm{Sr}$ and ${ }^{137} \mathrm{Cs}$ count rates of the centrifuged solutions were measured. 
perform all of the treatment steps in the proposed process. The composition of the NGLLLW surrogate was the same as shown in Table 4.1.

A diagram of the WTTF test system is shown in Fig. 11.1. The NGLLLW surrogate was pumped from the first feed drum to a 1-gal rapid-mix tank, where the surrogate combines with the treatment chemicals. From the rapid-mix tank, the solution flows to a larger 5-gal slow-mix tank, where residence time is provided for flocculation of the precipitated solids. The effluent from the slow-mix tank flows to the clarifier, where upflow contact with the sludge blanket occurs and where separation of the sludge and wastewater is accomplished. Sludge which accumulates in the clarifier is periodically removed from the bottom of the vessel and transferred to a holding container. Treated solution from the clarifier flows to an effluent tank which is provided for settling of any solid particles that may carry over from the clarifier. The effluent tank flows to a surge tank, which provides flooded suction for a metering pump which transfers the solution through the granular media filter column.

Two hundred liters of the NGLLLW simulant, containing $68 \mathrm{nCi} / \mathrm{L}(2500 \mathrm{~Bq} / \mathrm{L})$ ${ }^{85} \mathrm{Sr}$, was pumped from the first feed drum to the rapid mix tank at a rate of $500 \mathrm{~mL} / \mathrm{min}$. Strontium chloride (50 ppm) and Ferri-floc (25 ppm iron) were also added to the rapidmix tank. The simulant, containing precipitated strontium carbonate and ferric hydroxide, overflowed to the slow-mix tank, where 50 ppm of Calgon Pol-E-Z 2466 polymer was added and the precipitated solids flocculated and then overflowed to the clarifier. The solution was pumped from the surge tank through the filter column and then back to the second feed drum. After all of the surrogate was treated, sulfuric acid was pumped slowly into the treated solution until a $\mathrm{pH}$ of 8.0 was achieved.

After $\mathrm{pH}$ adjustment, the simulant was spiked with $135 \mathrm{nCi} / \mathrm{L}(5000 \mathrm{~Bq} / \mathrm{L}){ }^{137} \mathrm{Cs}$ prior to the second treatment step. The simulant was pumped through the treatment process as before. Potassium ferrocyanide and cobalt nitrate were added to the rapid-mix tank, where they reacted in situ to form $100 \mathrm{ppm}$ of KCCF. Calgon WT-2466I polymer (25 ppm) was added to the slow-mix tank. 
RETURN TO ALTERNATE FEED TANK

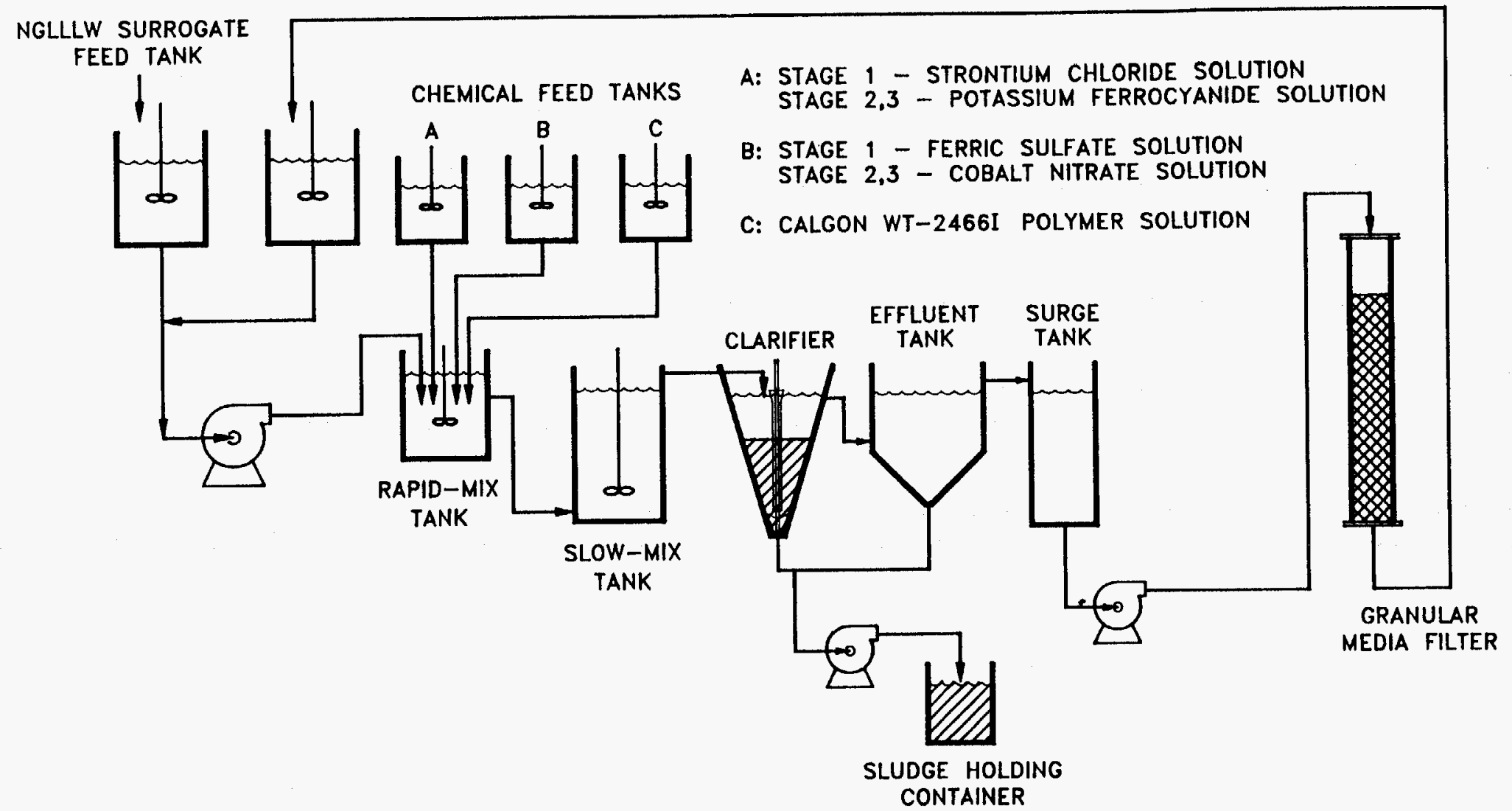

Fig. 11.1. Flow diagram for Wastewater Treatment Test Facility test system used for flowsheet demonstration. 
The filtered solution was returned to the previously emptied first feed drum. After all of the surrogate was treated, $\mathrm{NaAlO}_{2}$ was dissolved in water and then added to the solution at a concentration of $0.006 M$ (half that originally present in the NGLLLW) and the solution was spiked once again with $135 \mathrm{nCi} / \mathrm{L}{ }^{137} \mathrm{Cs}$. The ${ }^{137} \mathrm{Cs}$ treatment process was repeated as before, except that $50 \mathrm{ppm}$ KCCF was used.

A decontamination factor of 47 was achieved for ${ }^{85} \mathrm{Sr}$ in the first pass, and decontamination factors of 240 and 9.6 were obtained for ${ }^{137} \mathrm{Cs}$ in the second and third passes respectively. The ${ }^{85} \mathrm{Sr}$ decontamination factor is a factor of 2 lower than for previous laboratory-scale tests, but the ${ }^{137} \mathrm{Cs}$ decontamination factors are much lower than had been previously obtained. Samples of the treated water from the KCCF strikes were filtered through $0.45-\mu \mathrm{m}$ paper and resubmitted for analysis to determine if solids carryover was responsible for the low decontamination factors. A small amount of yellowgreen solids, presumably KCCF, was visible on the filter papers from both solutions. Filtering the effluents increased the decontamination factors to 2900 for the first KCCF strike and to 2300 for the second KCCF strike. The cumulative decontamination factor for ${ }^{137} \mathrm{Cs}$ was $6.7 \times 10^{6}$ in the filtered samples, which compares favorably with the laboratory-scale results.

Additional laboratory-scale testing was conducted to evaluate conditions which might interfere with the strontium and cesium removal processes. Since radioactive strontium removal from simulated NGLLLW with stable strontium is a coprecipitation process, the efficiency of removal could be affected by variations in the salt content of the initial solution. In addition, settling of the KCCF-cesium precipitate in the first KCCF strike could be affected by smaller amounts of $\mathrm{Al}(\mathrm{OH})_{3}$ present from solutions with lower aluminum concentrations. In a test to measure these effects, the simulated NGLLLW was diluted by a factor of 10 , except for strontium and cesium, which were retained at their normal concentrations. The solution was treated with $50 \mathrm{ppm}$ strontium $\left(\mathrm{SrCl}_{2}\right)+25 \mathrm{ppm}$ iron (ferric sulfate) followed by adjustment to $\mathrm{pH} 8$ and cesium removal in one strike with $100 \mathrm{ppm}$ in situ KCCF. Liquid-solid separations were made after the strikes by centrifugation for $30 \mathrm{~min}$ at $5000 \mathrm{rcf}$. Strontium behavior with the diluted solution was about the same as for full-strength simulated NGLLLW, but cesium removal efficiency 
was lower, probably because of difficulties in physically separating KCCF from lower-salt media (Table 11.4). The strontium decontamination factor was 137 in the strike with $\mathrm{SrCl}_{2}+$ ferric sulfate. However, the decontamination factor in adjustment of the decanted solution to $\mathrm{pH} 8$ was only 2.7 . This is about half the value usually measured and was likely due to the smaller amount of $\mathrm{Al}(\mathrm{OH})_{3}$ present. The cesium decontamination factor in the KCCF strike was only 265, compared with about 3000 usually measured from full-strength NGLLLW under these conditions. The lower decontamination factor was mostly due to difficulty in physically separating KCCF from the lower-salt solution, because the cesium decontamination was improved by filtration of the slurry or by addition of a polymer to aid flocculation. Filtration of one of the test solutions after the KCCF strike through a $0.45-\mu \mathrm{m}$ cellulose acetate membrane reduced the residual cesium concentration by a factor of 26 , to increase the cumulative decontamination factor to about 6400 . The addition of $20 \mathrm{ppm}$ Calgon WT-2466I polymer to the decanted solution reduced the cesium concentration by a factor of 6.5 , for a cumulative decontamination factor of about 1600 .

\section{PREILMMNARY SYSTEM DESIGN}

Based on the development studies performed thus far, preliminary system design is being developed for treatment of NGLLLW and MVST supernate using the most effective processes tested in laboratory and pilot studies. A diagram showing the existing ORNL liquid waste treatment facilities and the placement of the new LLLW treatment facility is shown in Fig. 1.1. The facility will receive LLLW from both the existing and the new MVSTs. The new MVSTs, to be provided in a FY 1994 line-item project, will receive pretreated NGLLLW directly from the Radiochemical Engineering Development Center, and the remaining NGLLLW would be processed through the existing LLLW evaporator prior to treatment. The waste will be treated, producing Greater-than-ClassLII secondary solid waste, and the effluent will be solidified as Class LII waste for on-site disposal. Process wastewater will be produced, consisting mainly of condensate from evaporation 
Table 11.4. Strontium and cesium removal from diluted simulated newly generated liquid low-level waste (NGLLLW) with a $\mathrm{SrCl}_{2}+$ ferric sulfate strike and a KCCF strike

\begin{tabular}{|c|c|c|c|c|}
\hline \multirow[b]{2}{*}{$\begin{array}{c}\text { Unit } \\
\text { operation }\end{array}$} & \multicolumn{2}{|c|}{ Strontium decontamination factor } & \multicolumn{2}{|c|}{ Cesium decontamination factor } \\
\hline & $\begin{array}{c}\text { Unit } \\
\text { operation }\end{array}$ & Cumulative & $\begin{array}{c}\text { Unit } \\
\text { operation }\end{array}$ & Cumulative \\
\hline $\mathrm{SrCl}_{2}+$ ferric sulfate strike & $505 \pm 87$ & $505 \pm 87$ & $1.00 \pm 0.01$ & $1.00 \pm 0.01$ \\
\hline pH Adjustment & $52.6 \pm 53$ & $25700 \pm 25900$ & $1.19 \pm 0.01$ & $1.19 \pm 0.01$ \\
\hline First KCCF strike & $0.33 \pm 0.06$ & $3004 \pm 0.04$ & $2337 \pm 815$ & $801 \pm 977$ \\
\hline Second KCCF strike & $0.45 \pm 0.04$ & $4080 \pm 389$ & $751 \pm 72$ & $(2.2 \pm 0.9) \times 10^{6}$ \\
\hline
\end{tabular}

'Procedure: Simulated NGLLLW was diluted by a factor of 10 with process water, $0.141 \mathrm{mg} \mathrm{Sr} / \mathrm{L}$ and $1.16 \mathrm{mg}$ $\mathrm{Cs} / \mathrm{L}$ were added, and the solution was traced with ${ }^{85} \mathrm{Sr}$ and ${ }^{137} \mathrm{Cs}$. $\mathrm{SrCl}_{2}+$ Ferric Sulfate Strike. Triplicate samples of the solution were mixed for $1 \mathrm{~h}$ on a magnetic stirrer with $50 \mathrm{ppm}$ strontium, added as $\mathrm{SrCl}_{2}$, and $25 \mathrm{ppm} \mathrm{Fe}^{3+}$, added as ferric sulfate. The samples were then mixed an additional one-half hour after the addition of 2 ppm Calgon Pol-E-Z2466. The samples were centrifuged for $30 \mathrm{~min}$ at $5000 \mathrm{rcf}$. The ${ }^{85} \mathrm{Sr}$ and ${ }^{137} \mathrm{Cs}$ count rates of the centrifuged solutions were measured. $\mathrm{pH}$ Adjustment. The centrifuged solutions were adjusted to $\mathrm{pH} 8$ with $5.1 \mathrm{~N} \mathrm{H}_{2} \mathrm{SO}_{4}$, mixed for $1 \mathrm{~h}$ on a magnetic stirrer, and centrifuged for $30 \mathrm{~min}$ at $5000 \mathrm{rcf}$. The ${ }^{85} \mathrm{Sr}$ and ${ }^{137} \mathrm{Cs}$ count rates of the centrifuged solutions were measured. First KCCF Strike. The adjusted solutions were mixed for $1 \mathrm{~h}$ with $100 \mathrm{ppm}$ of in situ KCCF slurry; then 2 ppm Calgon polymer WT-2466I polymer was added, and the solutions were mixed for an additional one-half hour. The solutions were centrifuged for $30 \mathrm{~min}$ at $5000 \mathrm{rcf}$, and the ${ }^{85} \mathrm{Sr}$ and ${ }^{137} \mathrm{Cs}$ count rates of the centrifuged solutions were measured. Second KCCF Strike. The centrifuged solutions were mixed for $1 \mathrm{~h}$ with $50 \mathrm{ppm}$ in situ KCCF slurry and then for an additional hour after the addition of $20 \mathrm{ppm}$ Calgon WT-2466I polymer. The samples were centrifuged for $30 \mathrm{~min}$ at $5000 \mathrm{rcf}$, and the ${ }^{85} \mathrm{Sr}$ and ${ }^{137} \mathrm{Cs}$ count rates of the centrifuged solutions were measured. 
operations. Gaseous discharges are expected as a consequence of nitrate destruction methods whichproduce ammonia and other gases. The design of the support facility in which the treatment will take place will depend largely on the concentration of radioactive materials in the waste. If generator source treatment and removal of TRU and fission products are not performed, the facility must include a hot cell and remotely operated systems. If the bulk of the contaminants are removed before entering the LLLW central collection system, the facility may be designed such that only portions of the system will require shielding.

The volume of NGLLLW requiring treatment is expected to be between 40,000 and 70,000 gal/year. If MVST supernates are treated also, the total volume will increase to about 90,000 to 120,000 gal/year. Assuming a maximum volume of 120,000 gal, this could be reasonably treated in 20,000-gal batches, one batch every 2 months. Two feed tanks will be necessary to allow isolation of one 20,000 -gal batch while another is being collected. Alternatively, two of the new 100,000-gal MVST storage tanks (to be provided in a FY 1994 line-item project) could be used as feed tanks for the treatment system. The treatment process could be designed for either batch or continuous processing. The choice will depend largely on the size of the equipment and the ease of operation and maintenance in hot-cell operation. Both approaches are discussed here.

\subsection{Batch Processing}

For the batch mode of operation, a 1000-gal batch size was chosen. An average processing rate of $330 \mathrm{gal} /$ day will be required to keep pace with a generation rate of 120,000 gal/year. The actual decontamination processes should require no longer than one 8- or 12-h workday for a 1000-gal batch. Extra time is allowed for analytical services and downtime. A flow diagram of the batch treatment system is shown in Fig. 12.1.

The initial step in the process involves treatment for removal of ${ }^{90} \mathrm{Sr}$ by coprecipitation. This involves the addition of normal strontium at a rate of $50 \mathrm{mg} / \mathrm{L}$ and the addition of ferric sulfate at a rate of $25 \mathrm{mg} / \mathrm{L}$ (as iron). Aqueous solutions of $\mathrm{SrCl}_{2}$ 


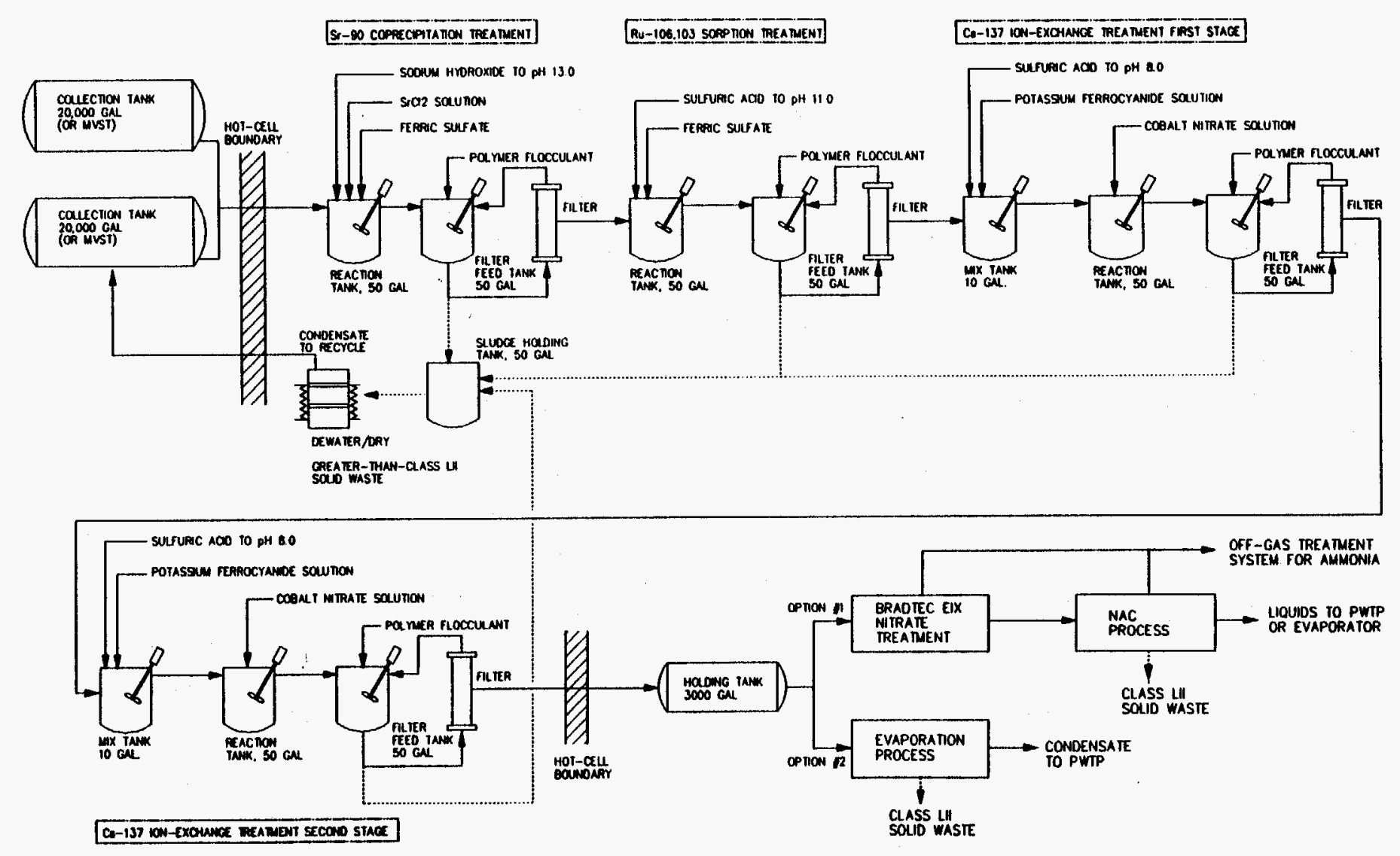

Fig. 12.1. Preliminary design flowsheet for centralized treatment of liquid low-level waste-batch mode. 
and ferric sulfate will be added to the reaction tank and allowed to stir for a minimum of $30 \mathrm{~min}$. A polymer flocculent solution will then be added to the tank, and gentle stirring will continue for an additional $15 \mathrm{~min}$. The stirrer will then be deenergized, and the precipitates will be allowed to settle. After settling for a specified time period, the solids will be transferred to a holding vessel and the clarified liquids will be transferred through a polishing filter to a second reaction tank for the second processing step. The device used as a polishing filter is yet to be determined, though cross-flow filtration with a metallic membrane has been tested successfully on MVST supernates. ${ }^{20}$

In the second treatment step, the $\mathrm{pH}$ will be adjusted to 11 using nitric or sulfuric acid. After $\mathrm{pH}$ adjustment, ferric sulfate is added once again at a concentration of $50 \mathrm{mg} / \mathrm{L}$ as iron. Due to limited development of a ruthenium removal process, the optimum reaction time for the ferric hydroxide is undetermined. After settling and removal of the ruthenium/iron precipitates, the waste is transferred to a third reaction vessel for the cesium removal treatment. In this vessel, the $\mathrm{pH}$ is first adjusted to 8.0, during which process the precipitation of aluminum hydroxide occurs. After pH adjustment, a solution of potassium ferrocyanide is added and allowed to stir until a uniform mixture is achieved. A cobalt nitrate solution is then added to create an equivalent of $100 \mathrm{mg} / \mathrm{L}$ of potassium cobalt hexacyanoferrate in the mixture. The mixture is allowed to stir for $30 \mathrm{~min}$, and a polymer flocculent is added for settling of the KCCFcesium reaction product. After settling and removal of the KCCF-cesium reaction product, the liquid is transferred to a fourth reaction vessel for a second stage of the KCCF treatment. In the second KCCF stage, a dosage of $50 \mathrm{mg} / \mathrm{L}$ of the KCCF is added, and similar settling and filtration operations are performed.

At this stage of the process, radionuclide removal operations are complete. The liquid will still contain a high concentration of salts and a moderate amount of radioactive ruthenium, though the activity of the waste should be low enough for treatment as a "contact-handled" waste. It is assumed that the next treatment step will involve concentrating the liquid using one of two options. This operation may take place outside of the hot-cell area, though extra shielding may be required for some areas of the system. 
Option 1, the preferred option, involves the potential use of both the BradTec EIX and the NAC processes discussed in Sect. 10. The BradTec process will use an electrochemical method for destroying the nitrate and producing ammonia, nitrogen, and water. This process will destroy a significant fraction of the nitrate while producing very little secondary solid waste. The NAC process will destroy most of the remaining nitrate by aluminum reduction and produce a stable, leach-resistant solid waste product. Any remaining liquids may either be discharged to the PWTP (if nitrate and ${ }^{103,106} \mathrm{Ru}$ concentrations are low enough) or evaporated to a Class LII salt cake. In both cases, ammonia off-gases must be destroyed by a catalytic incineration method. In Option 2 , an evaporator is used to concentrate the treated effluent to a Class LII salt cake, while allowing the condensate to be discharged to the PWTP. A Class LII salt cake may not be a desirable waste form due to the lack of leach resistance, especially if the effluent liquids are characteristically hazardous under the Resource Conservation and Recovery Act. These options will be evaluated and compared in future studies. The combined radiological sludges collected during the process will be dried and solidified in an acceptable manner for storage as Greater-than-Class-LII solid waste. Since small quantities of sludge are produced, a microwave drying process similar to that developed for WHPP may be appropriate. Further treatment of these sludges may be necessary to meet disposal criteria. Options for sludge treatment will be evaluated in future studies once the disposal method and criteria are better defined.

\section{Continuous Processing}

A continuous processing rate of $1 \mathrm{gal} / \mathrm{min}$ should be adequate to keep pace with the maximum expected generation rate of 120,000 gal/year. The continuous system shown in Fig. 12.2 is more complex, requires more equipment, and is likely more maintenance intensive than the batch operation. However, it is expected to require less space due to the smaller size of the equipment. In the initial processing step, the waste will combine with $\mathrm{SrCl}_{2}$ and ferric sulfate solutions to achieve dose rates of $50 \mathrm{mg} / \mathrm{L}$ as strontium and $25 \mathrm{mg} / \mathrm{L}$ as iron. The stirred reactor vessel must be sized to allow for a minimum holdup of $30 \mathrm{~min}$ for the mixture; therefore, a 50-gal vessel capacity was chosen. The reactor 


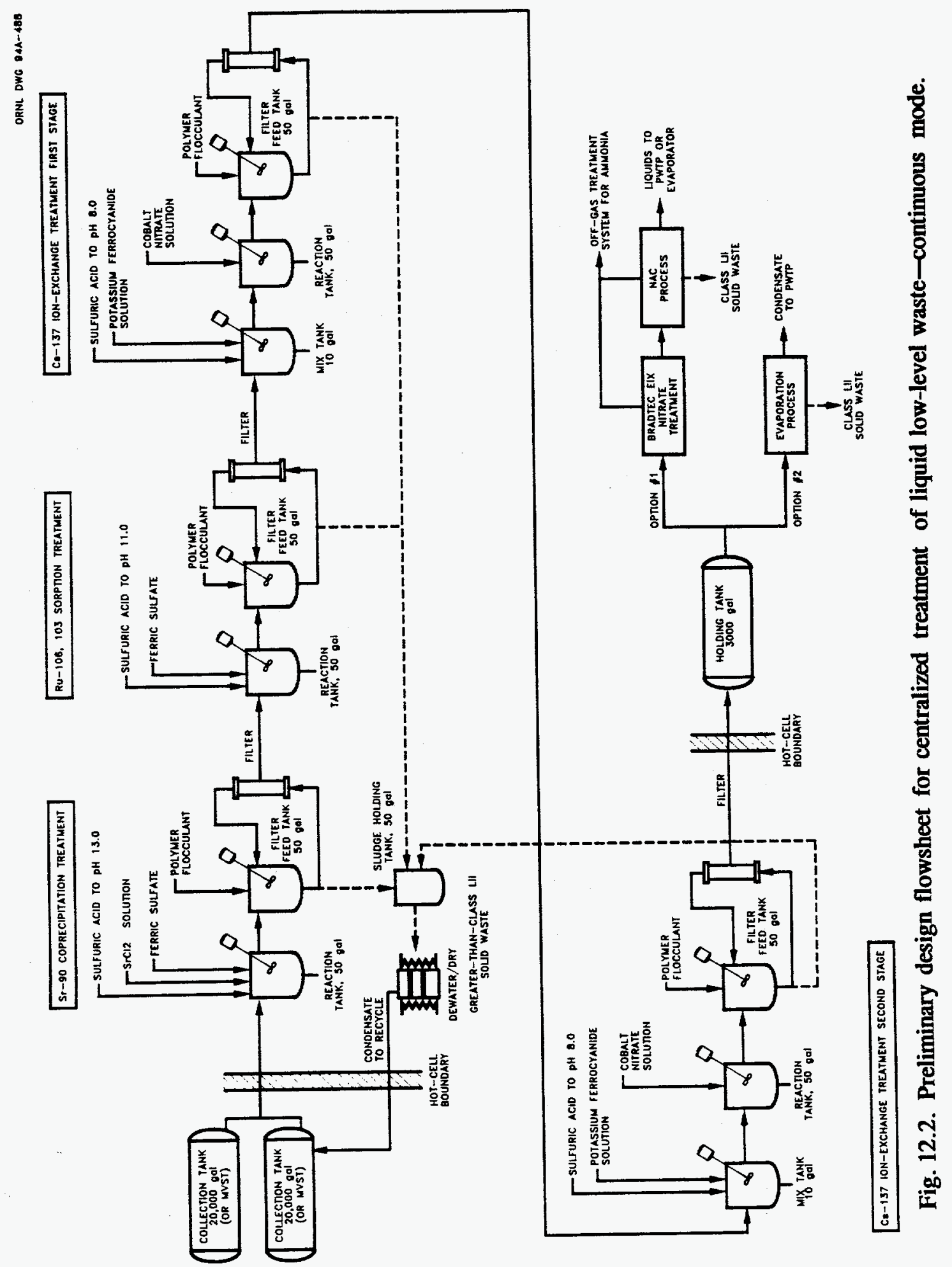


vessel will overflow to a combination settling/filtration (SF) vessel, where the flocculating agent is added and the precipitates settle and are concentrated by cross-flow filtration. The total volume of the SF vessel will be about $50 \mathrm{gal}$. The concentrated solids will be removed periodically from the SF vessel and transferred to a holding tank.

The filtered effluent will be transferred to the next processing step. In the next vessel, the $\mathrm{pH}$ of the waste will be lowered to 11.0 and the ferric sulfate solution added continuously to achieve a dose rate of $50 \mathrm{mg} / \mathrm{L}$ as iron. It is assumed that a 50 -gal vessel will be adequate for this operation. The waste will then flow to a SF vessel similar to that used to separate the strontium precipitate. The precipitates will be periodically transferred to the sludge holding tank. The vessels and equipment used for filtering the effluent from the SF vessel will also be similar to that used in the strontium treatment step.

The filtered effluent will flow to the first vessel used in the cesium removal operation. In this vessel, the $\mathrm{pH}$ is adjusted to 8.0 and the potassium ferrocyanide solution is added. This vessel need only be large enough to achieve adequate $\mathrm{pH}$ adjustment. A 10-gal vessel should be adequate. From the $\mathrm{pH}$ adjustment/potassium ferrocyanide addition operation, the waste will flow to a 50-gal vessel, where the cobalt nitrate solution is added and the KCCF is formed for the cesium ion-exchange reaction. A 50-gal SF vessel and the filtering operation will be similar to the other operations. The KCCF-cesium reaction product is removed periodically from the SF vessel and combined with other wastes in the sludge holding vessel. The equipment used for the second stage of $\mathrm{KCCF}$ treatment will be the same as that used in the first stage. As in the batch operation, the combined radiological sludges collected during the process will be dried and solidified in an acceptable manner for storage as Greater-than-Class-LII solid waste. The decontaminated effluent will be transferred outside of the hot cell to a holding tank for subsequent treatment. The options for treatment of the NGLLLW effluent are the same as those discussed in the batch operation.

In comparing batch with continuous operation, the batch operation requires larger vessels but is a less complex system with a smaller number of pumps that require periodic 
maintenance. The continuous operation requires more vessels and equipment, but less operating space. The size of the hot cell used for this operation may be a controlling factor in the cost of the project. In a hot cell operation, however, it is extremely important that the system be easily operated and maintained, which is an advantage for the batch operation. The batch and continuous modes of operation must be carefully evaluated and compared both from capital and operating cost standpoints. Both methods will be considered further in subsequent studies.

\section{SUMMARY AND CONCLUSIONS}

To improve management of LLLW at ORNL in the future, an improved system for centralized treatment of LLLW is needed. The system must also be capable of treating legacy LLLW stored in the MVSTs if the WHPP or an equivalent system is not available. The principal contaminants expected in NGLLLW are ${ }^{90} \mathrm{Sr},{ }^{137} \mathrm{Cs}$, and ${ }^{106,103} \mathrm{Ru}$, and the treatment methods discussed in this report focus on selective removal of the contaminants to create small volumes of Greater-than-Class-LII solid waste. Treated effluents will either be discharged to the environment or solidified as Class LII solid waste for on-site disposal. Strontium removal testing began with literature studies and scoping tests with several ion-exchange materials and sorbents. Chabazite and clinoptilolite zeolites, a resorcinol-formaldehyde-based resin, hydrous titanium oxide, magnesium hydroxide, sodium titanate, coprecipitation with calcium and strontium salts, and sorption by aluminum hydroxide were tested. The SRS resin and sodium titanate were somewhat effective, but experienced problems with consistency of performance between batches and suppliers. A combination of coprecipitation with stable $\mathrm{SrCl}_{2}$ and sorption onto aluminum hydroxide was the most effective for strontium removal.

In laboratory studies for cesium removal, chabazite zeolite, the SRS resin, KCCF, hydrous titanium phosphate, hydrous zirconium phosphate, Duolite CS-100 (Rohm and Haas), and ammonium molybdophosphate were tested. The most effective by far was the $\mathrm{KCCF}$ when applied as a finely divided slurry at a $\mathrm{pH}$ of 8.0. Laboratory tests for removal of ${ }^{106} \mathrm{Ru}$ included sorption and precipitation tests using $\mathrm{KCCF}$, cobalt sulfide, manganese dioxide, ferric hydroxide, and calcite. Ferric hydroxide sorption of ${ }^{106,103} \mathrm{Ru}$ is moderately 
effective, though improved treatment methods are being sought. Methods for destruction of nitrates are being developed in other DOE programs with wastes that are similar in nature to NGLLLW. The progress of these programs will be observed and, where necessary, waste-specific testing will be considered for further development. Pilot testing of ${ }^{90} \mathrm{Sr}$ and ${ }^{137} \mathrm{Cs}$ removal methods has begun, and solid/liquid separation operations are being developed. Plans are being prepared for development of solidification and stabilization methods for both Class LII and Greater-than-Class-LII solid wastes produced from these processes. Preliminary design of the treatment system is being conducted to determine potential type of equipment, size of equipment, operating characteristics, and facility needs.

\section{REFERENCES}

1. J. B. Berry, D. O. Campbell, D. D. Lee, and T. L. White, "Process Development for Remote-Handled Mixed-Waste Treatment," presented at the 1990 AIChE Summer National Meeting, San Diego, August 1990.

2. D. O. Campbell, D. D. Lee, and T. A. Dillow, Development Studies for Treatment of Low-Level Liquid Waste, ORNL/TM-11798, November 1991.

3. M. B. Sears, J. L. Botts, R. N. Ceo, J. J. Ferrada, W. H. Griest, J. M. Keller, and R. L. Schenley, Sampling and Analysis of Radioactive Liquid Wastes and Sludge in the Melton Valley and Evaporator Facility Storage Tanks at ORNL, ORNL/TM-11652, September 1990.

4. T. J. Abraham, S. M. DePaoli, A. B. Walker, and S. M. Robinson, Preliminary Analysis of the ORNL Liquid Low-Level Waste System, ORNL/TM-11250, July 1994.

5. W. E. Prout, E. R. Russell, and H. J. Groh, "Removal of Cesium from Aqueous Solutions by Ion Exchange," U.S. patent 3,296,123, January 3, 1967.

6. J. L. Collins et al., Development and Testing of Ion Exchangers for Treatment of Alkaline Wastes at ORNL, ORNL/TM-12315, March 1993.

7. J. P. Bibler, R. M. Wallace, and L. A. Bray, "Testing a New Cesium-Specific IonExchange Resin for Decontamination of Alkaline High-Activity Waste," presented at Waste Management' 90, Tucson, Arizona, February 1990.

8. C. B. Amphlett, Treatment and Disposal of Radioactive Wastes, Pergamon Press, New York, 1961. 
9. K. G. Seedhouse, J. Monahan, and G. Wallis, The Removal of Fission Products from Solution with a Precipitator-Column Treatment. Part I. Laboratory Trials, AERE ES/R 2220, 1958.

10. S. Y. Shiao, Y. Egozy, and R. E. Meyer, J. Inorg. Nucl. Chem. 43, 3309-3315 (1981).

11. R. G. Dosch, Final Report on the Application of Titanates, Niobates, and Tantalates to Neutralized Defense Waste Decontamination-Materials, Properties, Physical Forms, and Regeneration Techniques, SAND80-1212, 1981.

12. O. J. Heinonen, J. Lehto, and J. K. Meittinen, Radiochim. Acta 28, 93-96 (1981).

13. S. M. Robinson and J. M. Begovich, Treatment Studies at the Process Waste Treatment Plant at Oak Ridge National Laboratory, ORNL/TM-10352, March 1991.

14. R. Motoki et al., Treatment of Liquid Waste from the Production of Molybdenum-99 by ${ }^{233} U(n f){ }^{99}$ Mo Reaction. III. Treatment of Very Hot Liquid Waste, JAERI-M-84-015, January 1984.

15. W. D. Arnold, V. L. Fowler, J. J. Perona, and D. R. McTaggart, Treatability Studies for Decontamination of Melton Valley Storage Tank Supernate, ORNL/TM-12031, August 1992.

16. V. L. Fowler and J. J. Perona, Evaporation Studies on Oak Ridge National Laboratory Liquid Low-Level Waste, ORNL/TM-12243, March 1993.

17. G. W. Beaven, J. E. Cross, and E. W. Hooper, Study of the Behavior of Inorganic Ion Exchangers in the Treatment of Medium Active Effluent. Part $I V$. Further Studies on Absorber Performance, AERE-G-4381, July 1988.

18. L. L. Ames, Jr., "Process for Removing Ruthenium from Aqueous Solution", U.S. patent 3,136,715, February 1962.

19. K Imai, K Watari, and M. Izowa, J. Radiat. Res. 14,369 (1973).

20. V. L. Fowler and J. D. Hewitt, Cross Flow Filtration of Oak Ridge National Laboratory Liquid Low-Level Waste, ORNL/TM-10742, December 1989. 
Appendix A. WASTE COMPOSITION PROJECTION 


\section{Appendix A. WASTE COMPOSITION PROJECTION}

A list of all the major LLLW generators, generator activities, and general waste composition obtained from the LLLW database is given in Table A1. From this list, certain generators were eliminated after assuming program activities would be discontinued in the future or the waste would be treated at the source or in the process waste system. The generators and facilities eliminated from consideration are listed in Table A.2. LLLW volumes and contaminants from these facilities were ignored in the estimate of NGLLLW composition.

The impact of source pretreatment activities on waste composition was then considered. Activities are being planned at the Radiochemical Engineering Development Center (REDC) which will have a significant impact on future LLLW composition. To reduce the volume of TRU waste produced at the REDC, methods are being evaluated for improved segregation of the TRU components. In addition, the REDC is considering methods for improving operation of their off-gas scrubber system, which currently contributes large quantities of potassium salts to the LLLW system. The potassium salts increase the volume of LLLW concentrate from the evaporation process and could also interfere with future ion-exchange treatment processes. The REDC is also considering methods for segregating the organic components of their LLLW. For the purpose of estimating future waste composition, it will be assumed that the bulk of the TRU and organic components are removed and that the REDC scrubber operation has been modified to use sodium hydroxide instead of potassium hydroxide, though the equivalent molar quantity of sodium hydroxide and scrubber reaction products will be present in the waste. The estimated composition of the REDC waste to be treated in the new facility is shown in Table A.3 along with the other principal generators of NGLLLW.

Once the above factors were taken into account, the composition of the waste, based on reported volumes and contaminant amounts, was calculated and compiled in Table A.4. The principal radioactive contaminants in the waste include ${ }^{103,106} \mathrm{Ru},{ }^{137} \mathrm{Cs}$, ${ }^{90} \mathrm{Sr},{ }^{140} \mathrm{Ba}$, and ${ }^{95} \mathrm{Zr}$ in millicurie per liter quantities. The principal nonradioactive salts include sodium carbonate, sodium hydroxide, and sodium nitrate. It is obvious from the 
data that most of the contaminants are produced at the REDC as a result of radiochemical processing activities. Table A.5 gives the composition of the REDC waste alone. The principal contaminants are the same as those given in Table A.4, though concentrations are higher and the smaller quantities of some radionuclides are no longer present.

For the purpose of the development study, it was decided that waste with a composition similar to that given in Table A.5 should be used as simulated NGLLLW. It was assumed that whatever technology or material that is used to decontaminate this waste could also be used successfully on a more dilute solution such as that given in Table A.4. Of the six major contaminants of the NGLLLW, it was decided that the initial development work would center on removal of ${ }^{103,106} \mathrm{Ru},{ }^{137} \mathrm{Cs}$, and ${ }^{90} \mathrm{Sr}$. Both barium and zirconium are insoluble at the $\mathrm{pH}$ expected for the NGLLLW, and these contaminants would likely reside in TRU sludges expected to be removed in REDC source treatment operations. Cobalt-60 is present at a level that will be below the DOE 5400.5 Derived Concentration Guideline (DCG) once the treated NGLLLW is added to the process waste system and therefore will require no treatment. Mercuric nitrate, $\mathrm{Hg}\left(\mathrm{NO}_{3}\right)_{2}$ is present in the REDC waste as a result of an iodine scrubbing process. It was assumed that mercuric nitrate addition to the waste would cease in the future to avoid producing a mixed waste (radioactive and hazardous as defined by the Resource Conservation and Recovery Act); therefore, mercuric nitrate was not added to the surrogate. Table A.6 gives the composition of the surrogate waste solution used for the testing. 
Table A1. Summary of major LLLW generators, volumes, and compositions

(based on 1990 generator data)

\begin{tabular}{|c|c|c|}
\hline Source & $\begin{array}{l}\text { Dilute volume } \\
\text { (gal/month) }\end{array}$ & General waste composition \\
\hline W-1A tank & 4000 & $\begin{array}{l}\text { Contaminated groundwater with } \\
\text { becquerel per milliliter levels of } \\
\text { alpha, beta, and gamma activity. }\end{array}$ \\
\hline 3039 Stack & 3500 & $\begin{array}{l}\text { Many radionuclides in trace } \\
\text { quantities in dilute } \mathrm{NaOH} \text { solution. }\end{array}$ \\
\hline $\begin{array}{l}\text { High Flux Isotope } \\
\text { Reactor (HFIR) }\end{array}$ & 6200 & $\begin{array}{l}\text { DX regeneration solutions with } \\
\text { curie per year quantities of } \mathrm{Co}-60 \text {, } \\
\mathrm{Cr}-51, \mathrm{H}-3 \text {, and } \mathrm{W}-181 \text { in } 5 \% \text { nitric } \\
\text { acid solution. Five percent } \mathrm{NaOH} \\
\text { also used in regeneration. }\end{array}$ \\
\hline Building 3026 & 2700 & $\begin{array}{l}\text { Waste solutions containing small } \\
\text { quantities of } \mathrm{H}-3, \mathrm{Re}-188, \mathrm{~W}-188 \text {, } \\
\text { and traces of other radionuclides. }\end{array}$ \\
\hline $\begin{array}{l}\text { ORR, } 3042 \text {, and } \\
\text { BSR, } 3010\end{array}$ & 2433 & $\begin{array}{l}\text { IX regeneration solutions, } \\
\text { backwash solutions, and sump } \\
\text { wastewaters with traces of Co-60, } \\
\text { Cs-137, and others. }\end{array}$ \\
\hline Building 3525 & 1700 & $\begin{array}{l}\text { Waste solutions containing large } \\
\text { amounts of Cs-137 and smaller } \\
\text { quantities of TRU components. }\end{array}$ \\
\hline WC-8 & 1200 & Slightly contaminated groundwater. \\
\hline Building 3517 & 980 & $\begin{array}{l}\text { Waste decontamination solutions } \\
\text { containing Cs- } 137, \text { Sr- } 90 \text {, nitric } \\
\text { acid, and various cleaners. }\end{array}$ \\
\hline Building 3047 & 100 & $\begin{array}{l}\text { Slightly contaminated waste } \\
\text { solutions containing nitric acid, } \\
\text { axalic acid, } \mathrm{KMnO}^{4} \text {, and various } \\
\text { cleaners. }\end{array}$ \\
\hline Building 3029 & 20 & $\begin{array}{l}\text { Waste solutions with curie per year } \\
\text { quantities of Cs-137, Sr-90, Co-60, } \\
\text { and Ir-192, and also various } \\
\text { cleaners. }\end{array}$ \\
\hline REDC & 2611 & $\begin{array}{l}\text { Waste solutions from radiochemical } \\
\text { production activities containing } \\
\text { large quantities of fission products } \\
\text { and smaller quantities of TRU } \\
\text { compounds along with organic } \\
\text { extractants and off-gas scrubber } \\
\text { solutions. }\end{array}$ \\
\hline
\end{tabular}

Location: North tank farm near 3023. Collecting in-leakage from groundwater and rain.

Off-gas scrubber solution.

Process upgrades will include the use of nonregenerable IX to produce solid low-level waste and eliminate the production of LLLW.

Isotopes production and Health and Safety Research activities.

IX regeneration and backwash waters, filter pit sumps, floor drains, vault sumps.

Cutting and milling of irradiated reactor components.

Decontamination activities.

Pump pit in-leakage.

Cell washdowns and decontamination, source transfer, filter pit, and cell ventilation sumps.

Cell decontamination and Health and Safety Research activities.

Source fabrication facility; cell washdown activities.

Volume based on one HFIR target processing campaign plus one Mark 42 target campaign performed in 1 year. 
Table A.1 (continued)

\begin{tabular}{|c|c|c|c|}
\hline Source & $\begin{array}{l}\text { Dilute volume } \\
\text { (gal/mo.) }\end{array}$ & General waste composition & Notes \\
\hline $\begin{array}{l}4500 \text { area, } \\
\text { including the } \\
\text { following buildings }\end{array}$ & 756 total & $\begin{array}{l}\text { Contaminated wastewaters from } \\
\text { the } 4500 \text { area. }\end{array}$ & 4500 area wastes plus in-leakage. \\
\hline 4507 & 130 & Contaminated groundwater. & In-leakage into WC-12. \\
\hline 4501 & 11 & $\begin{array}{l}\text { Acidic and basic waste solutions } \\
\text { containing millicurie per liter } \\
\text { quantities of Cs-137 and Cs-137 } \\
\text { plus some transuranic components. }\end{array}$ & $\begin{array}{l}\text { Fission product release program } \\
\text { waste and other contaminated } \\
\text { wastewaters. }\end{array}$ \\
\hline $4500 \mathrm{~S}$ & 18 & $\begin{array}{l}\text { Wastewaters containing various } \\
\text { acids and bases along with tracer } \\
\text { levels of a variety of radionuclides. }\end{array}$ & $\begin{array}{l}\text { Research activities; analytical } \\
\text { chemistry. }\end{array}$ \\
\hline $4500 \mathrm{~N}$ & 2 & $\begin{array}{l}\text { Wastewaters and alcohols } \\
\text { containing trace quantities of a } \\
\text { variety of radionuclides. }\end{array}$ & Coal chemistry research activities. \\
\hline 3544 PWTP & 311 & $\begin{array}{l}\text { Spent nitric acid waste solution } \\
\text { concentrated by evaporation and } \\
\text { containing becquerel per milliliter } \\
\text { quantities of } S r-90 \text { and } C s-137 \text {. }\end{array}$ & $\begin{array}{l}\text { IX spent regenerant from the } \\
\text { PWTP. }\end{array}$ \\
\hline 2531 sumps & 2000 & Contaminated groundwater. & $\begin{array}{l}\text { Groundwater in-leakage at LLLW } \\
\text { evaporator facility. }\end{array}$ \\
\hline WC-9 & 410 & Contaminated groundwater. & In-leakage from off-gas drains. \\
\hline WC-5, WC-6 & 283 & Contaminated groundwater. & In-leakage. \\
\hline Building 3504 & 38 & $\begin{array}{l}\text { Wastewaters containing microcurie } \\
\text { per year quantities of various } \\
\text { radionuclides. }\end{array}$ & $\begin{array}{l}\text { Environmental Sciences well } \\
\text { samples and equipment } \\
\text { decontamination. }\end{array}$ \\
\hline Building 2026 & 113 & $\begin{array}{l}\text { Acidic wastewaters with low levels } \\
\text { of various radionuclides. }\end{array}$ & Analytical services. \\
\hline Building 3019 & 95 & $\begin{array}{l}\text { Acidic and basic waste solutions } \\
\text { with low levels of TRU compounds } \\
\text { and Cs-137. }\end{array}$ & $\begin{array}{l}\text { Radiochemical separations research; } \\
\text { waste treatment research; } \\
\text { radioisotope storage. }\end{array}$ \\
\hline Building 3025 & 26 & $\begin{array}{l}\text { Acidic wastes and alcohols } \\
\text { contaminated with Co- } 60 \text { and } \\
\text { traces of other radionuclides. }\end{array}$ & $\begin{array}{l}\text { Metallurgical studies of reactor } \\
\text { components. }\end{array}$ \\
\hline
\end{tabular}


Table A2. Summary of LILW generating facilities assumed to be removed from the LLLW system prior to implementation of new centralized LILW treatment system

\begin{tabular}{|c|c|c|c|c|c|}
\hline \multirow{2}{*}{$\frac{\text { Source }}{\text { W-1A tank }}$} & \multirow{2}{*}{$\begin{array}{l}\begin{array}{c}\text { Dilute } \\
\text { volume } \\
\text { (gal/month) }\end{array} \\
4000\end{array}$} & \multicolumn{2}{|c|}{$\begin{array}{c}\text { Major } \\
\text { radionuclides }\end{array}$} & \multirow{2}{*}{$\begin{array}{l}\begin{array}{c}\text { Other } \\
\text { constituents }\end{array} \\
\text { Sample: } 8 / 89 \\
\text { pH: } 8.8 \\
\text { Sp.g.: } 1.002 \\
\text { SO4: } 58 \mathrm{ppm} \\
\text { Cd: } 7.3 \mathrm{ppm} \\
\text { Pb: } 2 \mathrm{ppm} \\
\text { Hg: } 1 \mathrm{ppm} \\
\text { U: } 477 \mathrm{ppm}\end{array}$} & \multirow{2}{*}{$\begin{array}{l}\quad \text { Reason for } \\
\text { eliminating } \\
\text { Candidate for } \\
\text { diversion to the } \\
\text { process waste system } \\
\text { with eventual } \\
\text { removal remediation } \\
\text { of tank. }\end{array}$} \\
\hline & & $\begin{array}{l}\text { Sample: } 8 / 89 \\
\text { Units: Bq/mL } \\
\text { Gr. A: } 1100 \\
\text { Gr. B: } 1300 \\
\text { Am-241: } 54 \\
\text { Cm-244: } 9 \\
\text { Co-60: } 4.4 \\
\text { Cs-134: } 4.6 \\
\text { Cs-137: } 140 \\
\text { H-3: 2.6 } \\
\text { Pu-238: } 19 \\
\text { Pu-239: } 67 \\
\text { Sr-90: } 320 \\
\text { U-232: } 270 \\
\text { U-233: } 730 \\
\text { U-238: } 5\end{array}$ & $\begin{array}{l}\text { Sample: } 9 / 91 \\
\text { Units: Bg/mL } \\
\text { Gr. A: } 37.2 \\
\text { Gr. B: } 41.9 \\
\text { Co-60: }<0.06 \\
\text { Cs-137: } 15 \\
\text { H-3: } 10.8 \\
\text { Sr-90: } 16.3\end{array}$ & & \\
\hline 3039 Stack & 3500 & \multicolumn{2}{|c|}{$\begin{array}{l}\text { Many radionuclides in trace } \\
\text { quantities }\end{array}$} & $\begin{array}{l}\mathrm{NaOH}, 50 \%: 50 \\
\text { Lłyear }\end{array}$ & $\begin{array}{l}\text { Candidate for } \\
\text { diversion to the } \\
\text { process waste } \\
\text { system. }\end{array}$ \\
\hline HFIR & 6200 & \multicolumn{2}{|l|}{$\begin{array}{l}\text { Units: Ci/year } \\
\text { Cs-137: 0.01 } \\
\text { Co-60: } 8 \\
\text { Mn-54: } 0.3 \\
\text { Cr-51: } 40 \\
\text { H-3: } 4 \\
\text { Sc-46: } 0.4 \\
\text { Fe-59:0.1 } \\
\text { Zn-65: } 0.03 \\
\text { Ru-103: } 0.06 \\
\text { I-131: } 0.04 \\
\text { Ba-140: } 0.1 \\
\text { Ce-141: } 0.1 \\
\text { W-181: } 816\end{array}$} & $\begin{array}{l}\mathrm{HNO}_{3}, 5 \%: 3000 \\
\text { gal/year } \\
\text { NaOH, 5\%: } 5450 \\
\text { gal/year }\end{array}$ & $\begin{array}{l}\text { Process upgrades will } \\
\text { use non-regenerable } \\
\text { IX to produce solid } \\
\text { low-level waste and } \\
\text { divert some water to } \\
\text { the process waste } \\
\text { system. }\end{array}$ \\
\hline
\end{tabular}


Table A.2 (continued)

\begin{tabular}{|c|c|c|c|c|}
\hline Source & $\begin{array}{c}\text { Dilute volume } \\
\text { (gal/month) }\end{array}$ & $\begin{array}{c}\text { Major } \\
\text { radionuclides }\end{array}$ & $\begin{array}{c}\text { Other } \\
\text { constituents }\end{array}$ & Reason for eliminating \\
\hline Building 3026 & 2700 & $\begin{array}{l}\text { Units: mCi/year } \\
\text { H-3: 0.12 } \\
\text { Pd-103: trace } \\
\text { Ir-192: trace } \\
\text { Re-188: } 1.2 \\
\text { W-188: } 1.2 \\
\text { Traces of: Mn-54, } \\
\text { Fe-55, Fe-59, } \\
\text { Co-60, Os-191 }\end{array}$ & $\begin{array}{l}\text { Ajax*: } 6 \text { L/year } \\
\text { Fantastic*: } 6 \text { L/year } \\
\text { Mr. Clean*: } 4 \text { L/year }\end{array}$ & $\begin{array}{l}\text { Isotopes shutdown } \\
\text { program to put this } \\
\text { facility in surplus by } \\
1994 \text {. }\end{array}$ \\
\hline $\begin{array}{l}\text { ORR, 3042, and } \\
\text { BSR, } 3010\end{array}$ & 2433 & $\begin{array}{l}\text { Trace quantities of: } \\
\text { Co-60, Cs-137, } \\
\text { Cs-134, Mn-54, } \\
\text { Ru-106, Ra-226 }\end{array}$ & $\begin{array}{l}\mathrm{HNO}_{3}, 5 \%: 430 \text { gal/year } \\
\mathrm{NaOH}, 5 \%: 545 \text { gal/year } \\
\mathrm{H}_{2} \mathrm{SO}_{4}, 5 \%: 112 \text { galyear }\end{array}$ & $\begin{array}{l}\text { The IX systems for the } \\
\text { reactors are to be } \\
\text { upgraded to eliminate } \\
\text { LLLW and produce } \\
\text { only process wastewater. }\end{array}$ \\
\hline WC-8 & 1200 & & & $\begin{array}{l}\text { Candidate for diversion } \\
\text { to the process waste } \\
\text { system. }\end{array}$ \\
\hline Building 3517 & 980 & $\begin{array}{l}\text { Cs-137: } 500 \text { Ci/year } \\
\text { Sr-90: } 500 \mathrm{Ci} / \text { year }\end{array}$ & $\begin{array}{l}\mathrm{HNO}_{3} \text { : } 95 \mathrm{~L} / \text { year } \\
\text { Turco Decon* } 4502 \text { : } \\
11 \mathrm{~kg} / \text { year } \\
\text { Oxalic acid: } 11 \mathrm{~kg} / \text { year } \\
\mathrm{NaOH}: 11 \mathrm{~kg} / \text { year } \\
\text { Ajax*: unknown } \\
\text { Planisol*: unknown } \\
\text { Mr. Clean*: unknown }\end{array}$ & $\begin{array}{l}\text { Isotopes shutdown } \\
\text { program to put this } \\
\text { facility in surplus by } \\
1994 \text {. }\end{array}$ \\
\hline Building 3047 & 100 & $\begin{array}{l}\text { Trace quantities of: } \\
\text { Co-60, Gd-153, Eu-152, } \\
\text { and Eu-154 }\end{array}$ & $\begin{array}{l}\mathrm{HNO}_{3}, 3 \mathrm{M}: 60 \text { L/year } \\
\mathrm{NH}_{4} \mathrm{OH}: \text { unknown } \\
\mathrm{KMnO}_{4}: 60 \mathrm{lbs} / \text { year } \\
\text { Oxalic acid: } 721 \mathrm{lbs} / \text { year } \\
\text { Citric acid: } 24 \mathrm{lbs} / \text { year } \\
\text { Ajax*: } 48 \text { gal/year }\end{array}$ & $\begin{array}{l}\text { Isotopes shutdown } \\
\text { program to put this } \\
\text { facility in surplus by } \\
1994 \text {. }\end{array}$ \\
\hline Building 3029 & 20 & $\begin{array}{l}\text { Units: Ciyear } \\
\text { Cs-137: } 1 \\
\text { Sr-90: } 1 \\
\text { Co-60: } 1 \\
\text { Ir-192: } 3\end{array}$ & Cleaners: 10 gal/year & $\begin{array}{l}\text { Isotopes shutdown } \\
\text { program to put this } \\
\text { facility in surplus by } \\
1994 \text {. }\end{array}$ \\
\hline
\end{tabular}


Table A2 (continued)

\begin{tabular}{|c|c|c|c|c|}
\hline Source & $\begin{array}{c}\text { Dilute volume } \\
\text { (gal/month) }\end{array}$ & $\begin{array}{c}\text { Major } \\
\text { radionuclides }\end{array}$ & $\begin{array}{c}\text { Other } \\
\text { constituents }\end{array}$ & Reason for eliminating \\
\hline 3544 PWTP & 311 & $\begin{array}{l}\text { Gross beta: } 400 \\
\text { Bq/mL (Sr-90) } \\
\text { Cs-137: } 11 \mathrm{~Bq} / \mathrm{mL} \\
\text { Co-60: } 130 \mathrm{~Bq} / \mathrm{L}\end{array}$ & $\begin{array}{l}\text { HNO }_{3}: 8600 \text { lbs/year } \\
\text { NaOH: } 1600 \text { L/year } \\
\text { Ca: } 0.6 \% \\
\text { Mg: } 0.14 \% \\
\text { TDS: } 43 \mathrm{~g} / \mathrm{L}\end{array}$ & $\begin{array}{l}\text { Upgrades at PWTP will } \\
\text { eliminate LLLW and } \\
\text { produce only solid low-level } \\
\text { waste. }\end{array}$ \\
\hline 2531 sumps & 2000 & N/A & N/A & $\begin{array}{l}\text { Candidate for diversion to } \\
\text { the process waste system. }\end{array}$ \\
\hline WC-9 & 410 & N/A & N/A & $\begin{array}{l}\text { Candidate for diversion to } \\
\text { the process waste system. }\end{array}$ \\
\hline WC-5, wC-6 & 283 & $\mathrm{~N} / \mathrm{A}$ & N/A & $\begin{array}{l}\text { Candidate for diversion to } \\
\text { the process waste system. }\end{array}$ \\
\hline
\end{tabular}


Table A3. Summary of anticipated NGLILW generators, volumes, and waste composition

\begin{tabular}{|c|c|c|c|c|}
\hline Source & $\begin{array}{c}\text { Dilute } \\
\text { volume } \\
\text { (gal/month) }\end{array}$ & $\begin{array}{l}\text { Major } \\
\text { radionuclides }\end{array}$ & $\begin{array}{l}\text { Other } \\
\text { constituents }\end{array}$ & Notes \\
\hline REDC & 2611 & $\begin{array}{l}\text { Units: Cityear } \\
\text { Cs-137/134: } 11,795 \\
\text { Ru-103/106: } 15,596 \\
\text { Ba-140: } 1110 \\
\text { Sr-90: } 2300 \\
\text { Zr-95: } 764 \\
\text { Co-60: } 0.6\end{array}$ & $\begin{array}{l}\text { Units: lbs/year } \\
\mathrm{NaOH}: 3911 \\
\mathrm{Na}_{2} \mathrm{CO}_{3}: 16,250 \\
\mathrm{NaNO}_{3}: 1230 \\
\mathrm{NaAlO}_{2}: 300 \\
\mathrm{Na}_{2} \mathrm{~S}_{2} \mathrm{O}_{3}: 1.4 \\
\mathrm{Hg}\left(\mathrm{NO}_{3}\right)_{2}: 7.2 \\
\mathrm{HNO}: 97 \\
\mathrm{HCl}: 317 \\
\mathrm{LiCl}: 275 \\
\text { LiNO } \\
3: 0.15\end{array}$ & $\begin{array}{l}\text { Composition of REDC } \\
\text { waste after volatile off-gas } \\
\text { (VOG) scrubber } \\
\text { modifications and } \\
\text { pretreatment for removal } \\
\text { of TRU and organic } \\
\text { components. }\end{array}$ \\
\hline $\begin{array}{l}\text { Building } \\
3525\end{array}$ & 1700 & $\begin{array}{l}\text { Cs-137: } 50 \text { Ciryear } \\
\text { Trace quantities of: } \\
\text { U-233, U-235, U-238, Pu- } \\
\text { 239, } \mathrm{Th}-232 \text {, and } \mathrm{Kr}-85\end{array}$ & $\begin{array}{l}\mathrm{NaOH}: 19 \text { L/year } \\
\mathrm{HNO}_{3}: 19 \text { L/year } \\
\mathrm{Mr}^{*} \text { Clean*: } 19 \text { L/year } \\
\text { "Trioxide E", sodium } \\
\text { bisulfite: } 757 \text { L/year }\end{array}$ & $\begin{array}{l}\text { Grinding and cutting of } \\
\text { irradiated materials; } \\
\text { decontamination activities. }\end{array}$ \\
\hline 4501 & 11 & $\begin{array}{l}\text { Cs-137: } 7 \text { Ci/year } \\
\text { Th-232: } 20 \text { g/year } \\
\text { Cs-134: } 0.7 \text { Ci/year } \\
\text { U-238: } 100 \text { g/year } \\
\text { Trace quantities of: } \\
\text { Mixed Pu, Am-241/243, } \\
\text { Eu-152 }\end{array}$ & $\begin{array}{l}\mathrm{HNO}_{3}: 13 \text { gal/year } \\
\mathrm{HF}:<100 \text { ml/year } \\
\mathrm{NH}, \mathrm{OH}: 1 \text { gal/year } \\
\mathrm{NaOH}, 50 \%: 1 \mathrm{~L} / \text { year } \\
\mathrm{Comet}^{*}: 0.5 \mathrm{lb} / \text { year } \\
\mathrm{Mr} \text {. Clean*: } 0.3 \text { gal/year } \\
\text { Radiac wash: } 3 \mathrm{lb} / \text { year } \\
\text { Traces of: } \mathrm{HCl} \text {, } \\
\text { ammonium fluoride, } \\
\text { acetone }\end{array}$ & $\begin{array}{l}\text { Fission Product Release } \\
\text { Program and other } \\
\text { research. }\end{array}$ \\
\hline $4500 S$ & 18 & $\begin{array}{l}\text { Trace quantities of: } \\
\text { Sr-85, Cs-134/137, } \\
\text { Ra-226, U-232, U-238 }\end{array}$ & $\begin{array}{l}\mathrm{HNO}_{3}, \mathrm{HCl} \text {, alcohols, } \\
\text { potassium dichromate, } \\
\text { ferrous sulfate, vanadyl } \\
\text { sulfate, ammonium } \\
\text { molybdate, sulfamic acid }\end{array}$ & $\begin{array}{l}\text { Research activities; } \\
\text { analytical chemistry. }\end{array}$ \\
\hline $4500 \mathrm{~N}$ & 2 & $\begin{array}{l}\text { Trace quantities of: } \\
\text { C-14, Sr-85, Tc-95m, } \\
\text { Tc-99, Cs-137, Eu-152, } \\
\text { Ei-154, U-233, U-238, H- } \\
3\end{array}$ & Alcohols & $\begin{array}{l}\text { Coal chemistry research } \\
\text { activities. }\end{array}$ \\
\hline $\begin{array}{l}\text { Building } \\
3504\end{array}$ & 38 & $\begin{array}{l}\text { Units: } \mu \text { Cifyear } \\
\text { Sr-90: } 12 \\
\text { Co-60: } 6 \\
\text { Tc-99: } 0.1 \\
\text { Am-241: } 0.1\end{array}$ & $\begin{array}{l}\text { Contaminated } \\
\text { groundwater }\end{array}$ & $\begin{array}{l}\text { Environmental Sciences } \\
\text { well samples and } \\
\text { equipment } \\
\text { decontamination. }\end{array}$ \\
\hline $\begin{array}{l}\text { Building } \\
2026\end{array}$ & 113 & $\begin{array}{l}\text { Cs-137: } 4 \text { mCi/year } \\
\mathrm{U}-238: 1 \mu \mathrm{Ci} / \text { year }\end{array}$ & $\begin{array}{l}\mathrm{HCl}, 12 \mathrm{~N}: 240 \mathrm{~L} / \text { year } \\
\mathrm{HNO}_{3}, 15 \mathrm{~N}: 1.2 \mathrm{~L} / \text { year }\end{array}$ & Analytical services. \\
\hline
\end{tabular}


Table A.3 (continued)

\begin{tabular}{|c|c|c|c|c|}
\hline Source & $\begin{array}{c}\text { Dilute } \\
\text { volume } \\
\text { (gal/month) }\end{array}$ & $\begin{array}{c}\text { Major } \\
\text { radionuclides }\end{array}$ & $\begin{array}{c}\text { Other } \\
\text { constituents }\end{array}$ & Notes \\
\hline $\begin{array}{l}\text { Building } \\
3019\end{array}$ & 95 & $\begin{array}{l}\text { U-233: } 0.1 \text { Ci/year } \\
\text { U-235: } 22 \mu \mathrm{Ci} / \text { year } \\
\text { U-238: } 3 \mu \mathrm{Ci} / \text { year } \\
\text { Th-232: } 110 \mu \mathrm{Ci} / \text { year } \\
\text { Traces of: } \mathrm{Sr}-90, \mathrm{Cs}-137\end{array}$ & $\begin{array}{l}\mathrm{HNO}_{3}: 30 \text { L/year } \\
\mathrm{NaOH}: 10 \text { L/year } \\
\mathrm{HCl}: 10 \text { L/year }\end{array}$ & $\begin{array}{l}\text { Waste management } \\
\text { research; radiochemical } \\
\text { separations research; } \\
\text { radioisotope storage. }\end{array}$ \\
\hline $\begin{array}{l}\text { Building } \\
3025\end{array}$ & 26 & $\begin{array}{l}\text { Co-60: } 170 \mu \mathrm{Ci} / \mathrm{year} \\
\text { Traces of: } \mathrm{Mn}-54, \mathrm{Fe}-59\end{array}$ & $\begin{array}{l}\text { Mr Clean*: } 19 \mathrm{~L} / \text { year } \\
\text { Methanol: } 1.2 \mathrm{~kg} \text { /year } \\
\mathrm{H}_{2} \mathrm{SO}_{4}: 19 \mathrm{~kg} / \text { year } \\
\text { Acetone: } 45 \mathrm{~L} \text { /year }\end{array}$ & Metallurgical studies. \\
\hline
\end{tabular}


Table A.4. Calculated estimate of NGLLLW composition (Estimated volume $=55,000$ gal/year)

\begin{tabular}{|c|c|c|}
\hline Radionuclides & Total amount/year & NGLLLW conc. \\
\hline Cs-137,134 & $11,845 \mathrm{Ci}$ & $0.057 \mathrm{Ci} / \mathrm{L}$ \\
\hline Ru-103,106 & $15,596 \mathrm{Ci}$ & $0.075 \mathrm{Ci} / \mathrm{L}$ \\
\hline St -90 & $2300 \mathrm{Ci}$ & $11 \mathrm{mCi} / \mathrm{L}$ \\
\hline $\mathrm{Ba}-140$ & $1100 \mathrm{Ci}$ & $5.3 \mathrm{mCi} / \mathrm{L}$ \\
\hline Zr-95 & $764 \mathrm{Ci}$ & $3.7 \mathrm{mCi} / \mathrm{L}$ \\
\hline $\mathrm{Co}-60$ & $0.6 \mathrm{Ci}$ & $2.9{ }_{\mu} \mathrm{Ci} / \mathrm{L}$ \\
\hline Th-232 & $120 \mu \mathrm{Ci}$ & $0.57 \mathrm{nCi} / \mathrm{L}$ \\
\hline U-233 & $0.1 \mathrm{Ci}$ & $0.48 \mu \mathrm{Ci} / \mathrm{L}$ \\
\hline $\mathrm{U}-238$ & $35 \mu \mathrm{Ci}$ & $0.17 \mathrm{nCi} / \mathrm{L}$ \\
\hline U-235 & $22 \mu \mathrm{Ci}$ & $0.1 \mathrm{nCi} / \mathrm{L}$ \\
\hline $\mathrm{U}-232$ & Trace (Tr) & $\mathrm{Tr}$ \\
\hline $\mathrm{Pu}-239$ & $\mathrm{Tr}$ & $\mathrm{Tr}$ \\
\hline $\mathrm{Kr}-85$ & $\mathrm{Tr}$ & $\operatorname{Tr}$ \\
\hline Sr-85 & $\mathrm{Tr}$ & $\mathrm{Tr}$ \\
\hline $\mathrm{Ra}-226$ & $\operatorname{Tr}$ & $\operatorname{Tr}$ \\
\hline Eu-152,154 & $\mathrm{Tr}$ & $\mathrm{Tr}$ \\
\hline C-14 & $\mathrm{Tr}$ & $\mathrm{Tr}$ \\
\hline Ei-154 & $\mathbf{T r}$ & $\mathbf{T r}$ \\
\hline H-3 & $\mathbf{T r}$ & $\mathrm{Tr}$ \\
\hline $\begin{array}{l}\text { Nonradioactive } \\
\text { components }\end{array}$ & Quantity (lb/year) & Molar concentration \\
\hline $\mathrm{NaOH}$ & 3,121 & 0.17 \\
\hline $\mathrm{NaNO}_{3}$ & 1,650 & 0.043 \\
\hline $\mathrm{NaAlO}_{2}$ & 300 & 0.0068 \\
\hline $\mathrm{Na}_{2} \mathrm{CO}_{3}$ & 16,250 & 0.33 \\
\hline $\mathrm{NaCl}$ & 921 & 0.035 \\
\hline $\mathrm{NaHSO}_{3}$ & 1,900 & 0.04 \\
\hline $\mathrm{Na}_{2} \mathrm{SO}_{4}$ & 58 & 0.0009 \\
\hline $\mathrm{LiCl}$ & 275 & 0.014 \\
\hline $\mathrm{Hg}\left(\mathrm{NO}_{3}\right)_{2}$ & 7.2 & Nil \\
\hline
\end{tabular}


Tabie A. Estimated NGLLLW composition - REDC waste only (Estimated volume $=31,300$ gal/year)

\begin{tabular}{|c|c|c|}
\hline Radionuclides & Total amount/year (Ci) & NGLLLW conc. \\
\hline Cs-137,134 & 11,800 & $100 \mathrm{mCi} / \mathrm{L}$ \\
\hline Ru-103,106 & 15,600 & $130 \mathrm{mCi} / \mathrm{L}$ \\
\hline Sr-90 & 2300 & $20 \mathrm{mCi} / \mathrm{L}$ \\
\hline $\mathrm{Ba}-140$ & 1100 & $9.4 \mathrm{mCi} / \mathrm{L}$ \\
\hline$Z_{r}-95$ & 760 & $6.4 \mathrm{mCi} / \mathrm{L}$ \\
\hline $\mathrm{Co}-60$ & 0.6 & $5.1 \mu \mathrm{Ci} / \mathrm{L}$ \\
\hline $\begin{array}{c}\text { Nonradioactive } \\
\text { components }\end{array}$ & Quantity (lb/year) & Molar concentration \\
\hline $\mathrm{NaOH}$ & 3,500 & 0.34 \\
\hline $\mathrm{NaNO}_{3}$ & 1,360 & 0.06 \\
\hline $\mathrm{NaAlO}_{2}$ & 300 & 0.012 \\
\hline $\mathrm{Na}_{2} \mathrm{CO}_{3}$ & 16,250 & 0.59 \\
\hline $\mathrm{NaCl}$ & 500 & 0.034 \\
\hline $\mathrm{LiCl}$ & 275 & 0.025 \\
\hline $\mathrm{Hg}\left(\mathrm{NO}_{3}\right)_{2}$ & 7.2 & 0.000085 \\
\hline
\end{tabular}

Table A6. Simulated NGLLLW composition

\begin{tabular}{lll}
\hline \multicolumn{1}{c}{ Radionuclides } & \multicolumn{1}{c}{ Total amount/year (Ci) } & \multicolumn{1}{c}{ NGLLLW conc. } \\
\hline $\mathrm{Cs}-137,134$ & 11,800 & $100 \mathrm{mCi} / \mathrm{L}$ \\
$\mathrm{Ru}-103,106$ & 15,600 & $130 \mathrm{mCi} / \mathrm{L}$ \\
$\mathrm{Sr}-90$ & 2,300 & $20 \mathrm{mCi} / \mathrm{L}$ \\
\hline Nonradioactive & \multicolumn{2}{c}{ Quantity (lb/year) } \\
components & \multicolumn{2}{c}{ Molar concentration } \\
\hline $\mathrm{NaOH}$ & 3,500 & 0.34 \\
$\mathrm{NaNO}$ & 1,360 & 0.06 \\
$\mathrm{NaAlO}$ & & 0.012 \\
$\mathrm{Na} \mathrm{CO}_{3}$ & 300 & 0.59 \\
$\mathrm{NaCl}$ & 16,250 & 0.034 \\
$\mathrm{LiCl}$ & 500 & 0.025 \\
\hline
\end{tabular}


Appendix B. MASS TRANSFER ANALYSIS FOR IN-TANK EVAPORATION 


\section{Appendix B. MASS TRANSFER ANALYSIS FOR IN-TANK EVAPORATION}

The objective of this analysis is a prediction of the amount of carbon dioxide absorbed in the supernate during ITE. This is necessary to characterize the feed to WHPP or whatever process is put in place to decontaminate the MVST supernates. The MVSTs each contain five 1-in. pipes carrying air down 8 in. from the bottom of each tank. The air is released through slots in the 1-in. pipe wall into 6-in. draft tubes rising from the bottom of the tank to heights of $2.5 \mathrm{ft}$ (two) and $6.5 \mathrm{ft}$ (three). The tanks are $12 \mathrm{ft}$ in diameter, and sludge levels in the tanks vary from about 1.5 to $5.5 \mathrm{ft}$.

The presence of the sludge and the draft tubes makes a bubble-modeling approach for the mass transfer rates very uncertain. Therefore, the most trustworthy procedure appears to be to extract a mass transfer coefficient from the evaporation data in ORNL/TM-12036 ${ }^{1}$ and then apply it to the absorption of carbon dioxide.

The results are

1. About one-half of the carbon dioxide entering with the sparge air will be absorbed.

2. For $600 \mathrm{ft}^{3} / \mathrm{min}$ sparging six tanks, about $100 \mathrm{lb}$-mols of carbon dioxide will be absorbed each year. This would lower the $\mathrm{pH}$ of $200,000 \mathrm{gal}$ from 13 to about 12 in one year and then to below 9 in the second year. Treatment of the supernate for cesium removal with ferrocyanates is much more effective in the $\mathrm{pH}$ range of 8 to 11 .

Task 1 - Extract a mass transfer coefficient-interfacial area product from the evaporation data.

Two data points will be used: at $274 \mathrm{ft}^{3} / \mathrm{min}$, exit air saturation $86 \%$ at $430 \mathrm{ft}^{3} / \mathrm{min}$, exit air saturation $73 \%$

The mass transfer process will be analyzed in two steps:

I. Evaporation during bubble formation

II. Evaporation during bubble rise

The literature on mass transfer in bubble columns and spray columns with both gas-liquid and liquid-liquid systems presents conclusive evidence that mass transfer during bubble or drop formation is always a significant part (often the biggest part) of the total transfer. For evaporation, there is no liquid-side mass transfer resistance. The gas in contact with the liquid interface of a bubble can be taken to be saturated.

$$
R_{I}=F_{G}\left(C_{\text {sat }}-C_{\text {in }}\right)=G\left(C_{1}-C_{\text {in }}\right),
$$


where

$\mathrm{R}_{\mathrm{I}}=$ rate of evaporation during bubble growth, $\mathrm{mols} / \mathrm{min}$,

$F_{G}=$ product of a mass transfer coefficient and average surface area in the formation period, $\mathrm{ft}^{3} / \mathrm{min}$,

$\mathrm{C}=$ concentration of water vapor in air, $\mathrm{mols} / \mathrm{ft}^{3}$,

subscripts: in-concentration in air leaving sparge tube

sat-concentration at saturation,

1 -concentration at end of bubble growth and start of rise,

$\mathrm{G}=$ air flow rate, $\mathrm{ft}^{3} / \mathrm{min}$

Solving for $\mathrm{C}_{1}$ :

$$
\begin{aligned}
& F_{G} / G=\left(C_{1}-C_{i n}\right) /\left(C_{\text {sat }}-C_{i n}\right), \\
& C_{1}=C_{i n}+F_{G} / G\left(C_{s a t}-C_{i n}\right) .
\end{aligned}
$$

To obtain the rate during bubble rise, write a balance over a differential height, $\mathrm{dz}$ :

$$
\mathrm{G} d C=k_{G} a d z\left(C_{s a t}-C\right) \text {. }
$$

This expression is integrated over the concentration range $C_{1}$ to the concentration in the air leaving the liquid surface, $\mathrm{C}_{\mathrm{out}}$.

$$
\left(C_{\text {sat }}-C_{\text {out }}\right) /\left(C_{\text {sat }}-C_{1}\right)=\exp \left(-k_{G} a H / G\right) \text {, }
$$

where $\mathrm{H}$ is the height of the bubble rise through the supernate.

The intermediate concentration $C_{1}$ can be eliminated between Eq. (1) and (2), leaving an expression with two unknowns, the two mass transfer coefficients. These are obtained using the data at 274 and $430 \mathrm{ft}^{3} / \mathrm{min}$.

\section{Supernate} temperature, $\mathrm{C}$

$\underline{\mathrm{C}}_{\text {sat }}$

$\underline{C}_{\text {in }}$

$\underline{\mathrm{C}}_{\text {out }}$

$274 \mathrm{ft}^{3} / \min$

11.9

3.44E-5

$0.86 \mathrm{E}-5$

2.96E-5

$430 \mathrm{ft}^{3} / \min$

11.4

3.31E-5

$0.86 \mathrm{E}-5$

2.42E-5

Solving for the mass transfer coefficients,

$$
\begin{gathered}
F_{G}=125 \mathrm{ft}^{3} / \mathrm{min}, \\
\mathrm{k}_{\mathrm{G}} \mathrm{a}=35.8 \mathrm{ft}^{2} / \mathrm{min} .
\end{gathered}
$$


The mass transfer coefficient during bubble rise is the product of $k_{G}$ ( $f t / m i n$ ) and the interfacial area per unit of height $\left(\mathrm{ft}^{2} / \mathrm{ft}\right)$. George Llewellyn of Engineering used a model for bubbles in water which resulted in interfacial areas of the order of $1000 \mathrm{ft}^{2}$ per sparge tube flowing at $20 \mathrm{ft}^{3} / \mathrm{min}$. Fluid depth in the MVST's is about $8 \mathrm{ft}$, giving an interfacial area of the order of $125 \mathrm{ft}^{2} / \mathrm{ft}$. This would indicate a value for $\mathrm{k}_{\mathrm{G}}$ of the order of $0.3 \mathrm{ft} / \mathrm{min}$, or 0.15 $\mathrm{cm} / \mathrm{s}$, which is reasonable.

Using $F_{G}$ to calculate $C_{1}$, values of $2.0 \mathrm{E}-5$ and $1.6 \mathrm{E}-5$ are found for the two runs. These indicate that about half of the evaporation takes place during bubble formation.

Task 2 - Absorption of Carbon Dioxide

For the absorption of carbon dioxide, the assumption will be made that the gas-side resistance controls. The air contains only 0.0003 mol fraction carbon dioxide as it enters, so the concentration gradient is small. The reaction of hydroxide and carbon dioxide in the liquid will be in either the fast or instantaneous regime, with a large reaction rate enhancement factor. These factors make the assumption of gas-side resistance controlling plausible, and the assumption is necessary if the mass transfer coefficients obtained from the evaporation experiments are to be applied to carbon dioxide absorption.

Rate expressions for absorption can be written as follows:

$$
R_{I}=F_{G}\left(C_{i n}-0\right)=G\left(C_{i n}-C_{1}\right),
$$

where the concentration of the gas in contact with the liquid phase is assumed to have a carbon dioxide concentration of zero because of the reaction with hydroxide.

$$
C_{1} / C_{\text {in }}=\left(G-F_{G}\right) / G \text {. }
$$

Absorption during the bubble rise is obtained as before with a balance over a differential height:

$$
-G d C=k_{G} a d z(C-0) .
$$

Integration yields

$$
C_{\text {out }} / C_{1}=\exp \left(-k_{O^{a}} H / G\right)
$$

Combining Eq. (3) and (4) to eliminate $C_{1}$ yields

$$
C_{\text {out }} / C_{\text {in }}=\left[\left(G-F_{G}\right) / G\right] \exp \left(-k_{G} a H / G\right) \text {. }
$$

Before applying this equation, the mass transfer coefficients for the air-water system must be adjusted for the air-carbon dioxide system. Surface renewal theory indicates that mass transfer coefficients should depend on the square root of diffusivity, and this is supported by a great deal of published data. The diffusivity of the air-water system is $0.288 \mathrm{~cm}^{2} / \mathrm{s}$, and that 
for air-carbon dioxide is $\mathbf{0 . 1 4 2}$. Therefore, the coefficients for evaporation must be multiplied by a factor of

$$
\begin{aligned}
& (0.142 / 0.288)^{1 / 2}=0.702 \\
& 125 \times 0.702=87.8 \\
& 35.8 \times 0.702=25.1
\end{aligned}
$$

Using an air flow rate of $400 \mathrm{ft}^{3} / \mathrm{min}$ for the four tanks of the evaporation experiment, a value of $\mathrm{C}_{\text {out }} / \mathrm{C}_{\mathrm{in}}=0.47$ is predicted. Of the gas absorbed, about $40 \%$ is absorbed during bubble formation.

The six tanks for which ITE is planned contain about 200,000 gal of supernate. From ORNL/TM-11652, volumes and pH's are as follows:

$\begin{array}{lllllll} & \underline{\mathrm{W}-24} & \underline{\mathrm{W}-25} & \underline{\mathrm{W}-26} & \underline{\mathrm{W}-27} & \underline{\mathrm{W}-28} & \text { W-31 } \\ \text { pH } & 13.1 & 12.5 & 11.2 & 11.8 & 9.1 & 11.7 \\ \begin{array}{l}\text { Volume } \\ \text { (gal) }\end{array} & 34,200 & 24,000 & 30,100 & 29,200 & 43,600 & 39,600\end{array}$

Assuming that each tank is sparged at $100 \mathrm{ft}^{3} / \mathrm{min}$, the inlet air contains 0.0003 mol fraction carbon dioxide, and half of the entering carbon dioxide is absorbed. Each tank would add about $20 \mathrm{lb}$-mols of carbon dioxide per year, which is $40 \mathrm{lb}$-equivalents of acid. To put this in context, lab experiments have shown that about $0.2 \mathrm{eq} / \mathrm{L}$ of $\mathrm{HCl}$ were required to lower the $\mathrm{pH}$ of simulated W-29 supernate from 13 to 12 , which converts to about $1.7 \mathrm{lb}$-mols/1000 gal. For W-24, about $34 \times 1.7=58 \mathrm{lb}$-equiv would be required to lower the $\mathrm{pH}$ to 12 . About 1.5 years would be required for this to occur in W-24. The other tanks would drop several $\mathrm{pH}$ units in 1 year.

\section{REFERENCE}

1. J. F. Walker, J. J. Perona, and S. M. Robinson, In-Tank Evaporator Demonstrations During 1990/1991 at the ORNL Melton Valley Storage Tank, ORNL/TM-12036, Oak Ridge National Laboratory, October 1992. 


\section{INTERNAL DISTRIBUTION}

\begin{tabular}{|c|c|c|c|c|c|}
\hline 1. & P. E. Arakawa & 62. & S. B. Garland & 104. & W. T. Thompson \\
\hline 2-11. & W. D. Arnold & 63. & R. K Genung & 105. & J. R. Trabalka \\
\hline 12. & P. L. Askew & 64. & J. R. Hightower & 106. & P. A. Taylor \\
\hline 13. & J. S. Baldwin & 65. & R. J. Hydzik & 107. & M. W. Tull \\
\hline 14. & P. T. Barton & 66. & C. M. Kendrick & 108. & D. W. Turner \\
\hline 15. & J. M. Begovich & $67-76$ & T. E. Kent & 109. & J. H. Wilson \\
\hline 16. & J. T. Bell & 77. & F. C. Kornegay & 110. & S. D. Van Hoesen \\
\hline 17. & C. E Benson & 78. & J. R. Lawson & 111. & R. I. Van Hook \\
\hline 18. & W. D. Bond & 79. & D. D. Lee & 112. & J. F. Walker \\
\hline $19-28$. & D. A. Bostick & 80. & J. L. Maddox & 113. & G. D. West \\
\hline 29. & R. R. Brunson & 81. & C. P. Manrod & 114. & E. L. Youngblood \\
\hline 30-39. & M. W. Burgess & 82. & R. C. Mason & 115. & D. S. Zill \\
\hline 40. & M. D. Boring & 83. & A. J. Mattus & 116. & Central Research \\
\hline 41. & B. S. Bowers & 84. & B. C. McClelland & & Library \\
\hline 42. & C. H. Byers & 85. & E. W. McDaniel & 117. & Document \\
\hline 43. & E. D. Collins & 86. & B. A. Moyer & & Reference \\
\hline 44. & J. L. Collins & 87. & L. E. McNeese & & Section \\
\hline 45. & D. A Conatser & 88. & D. R. McTaggart & $118-119$. & Laboratory Records \\
\hline 46. & T. B. Conley & 89. & S. R. Michaud & 120. & Laboratory Records, \\
\hline 47. & A. C. Coroneos & 90. & T. H. Monk & & R.C. \\
\hline 48. & A. G. Croff & 91. & J. R. Parrott, Jr. & 121. & ORNL Patent \\
\hline 49. & D. L. Daugherty & 92. & B. D. Patton & & Section \\
\hline 50. & S. M. DePaoli & 93. & D. J. Peterson & & \\
\hline 51. & D. J. Davidson & 94. & W. R. Reed & & \\
\hline 52. & J. S. Davidson & 95. & S. M. Robinson & & \\
\hline 53. & B. Z. Egan & 96. & S. T. Rudell & & \\
\hline 54. & C. A. Easterday & 97. & T. F. Scanlan & & \\
\hline 55. & J. T. Etheridge & 98. & C. B. Scott & & \\
\hline 56. & J. R. Forgy, Jr. & 99. & R. B. Shelton & & \\
\hline 57. & V. L. Fowler & 100. & J. L. Snyder & & \\
\hline 58. & C. E. Frye & 101. & R. C. Stewart & & \\
\hline 59. & W. Fulkerson & 102. & L. E. Stratton & & \\
\hline 60. & T. M. Gilliam & 103. & J. H. Swanks & & \\
\hline 61. & B. B. Guo & & & & \\
\hline
\end{tabular}

\section{EXTERNAL DISTRIBUTION}

122. Office of Assistant Manager, Energy Research and Development, DOE-OR, P.O. Box 2001, Oak Ridge, TN 37831

123-124. Office of Scientific and Technical Information, P. O. Box 62, Oak Ridge, TN 37831

125. Joseph J. Perona, Chemical Engineering Department, The University of Tennessee, Dougherty Hall, Knoxville, Tennessee 37996-2200. 